\title{
STORMWATER MANAGEMENT: MUNICIPAL POLICIES IN ONTARIO FOR MANAGING RAIN WHERE IT FALLS THROUGH GREEN INFRASTRUCTURE
}

By

Wayne Savio Coutinho

B.Sc. Environmental Science, University of Toronto, 1999

\author{
A Major Research Paper \\ presented to Ryerson University \\ in partial fulfillment of \\ the requirements for the degree of \\ Master of Planning \\ in Urban Development
}

Toronto, Ontario, Canada, 2016

(C) Wayne Coutinho 2016 


\section{Author's Declaration for Electronic Submission of a MRP}

I hereby declare that I am the sole author of this MRP. This is a true copy of the MRP, including any required final revisions.

I authorize Ryerson University to lend this MRP to other institutions or individuals for the purpose of scholarly research

I further authorize Ryerson University to reproduce this MRP by photocopying or by other means, in total or in part, at the request of other institutions or individuals for the purpose of scholarly research. I understand that my MRP may be made electronically available to the public. 
STORMWATER MANAGEMENT: ONTARIO MUNICIPAL POLICIES FOR GREEN INFRASTRUCTURE

STORMWATER MANAGEMENT: MUNICIPAL POLICIES IN ONTARIO FOR MANAGING RAIN WHERE IT FALLS THROUGH GREEN INFRASTRUCTURE

Wayne Coutinho

Master of Planning in Urban Development, 2016

Ryerson University

\section{ABSTRACT}

This research explores the state of practice for managing rain where it falls in southern Ontario through green infrastructure policies. A literature review and first hand experience from municipalities provided the understanding of the issues to wide-spread adoption. Stormwater runoff is a significant issue within urban settings, contributing to localized riverine and/or basement flooding that impacts municipal infrastructure, residences, and environmental quality of waterways. Traditional grey infrastructure, an engineered approach of collection and treatment facilities, addresses concerns with combined sewer overflow (CSO), but is not an effective system for Stormwater Management (SWM), evident by the increase in flooding and pollution from intensified rain events, with climate change.

Supported by evidence in published literature over the last decade, Low Impact Development (LID) principles have demonstrated effective results for cold climates, provided life costs-analysis, and a planning framework to determine suitable placement for installations. Co-benefits of Green Stormwater Infrastructure (GSI) are especially valued such as building great communities to live in with "high functioning" urban green spaces. This evidence suggests that managing stormwater runoff locally is a more cost effective and sustainable than end-of-pipe solutions. The study revealed best practices and lessons learned from municipalities implementing GSI for the Right-of-Way (ROW) though “Green Streets" and on private lands through LID to manage rain where it falls. In Ontario, GSI is at an early adoption stage. The findings support a planning rationale for a coordinated approach to implement, finance, and operate GSI programs for both private lands and in the public ROW for SWM.

Keywords: stormwater management, green infrastructure, municipal policy, urban design, low impact development (LID), intensification, climate change, sustainability. 


\section{ACKNOWLEDGEMENTS}

Foremost, I am eternally grateful to my loving wife, Hanusha, and my adoring son, William, who showered me with love and unwavering support. I am also thankful to William's grandparents for helping to keep him entertained during my studies. I was privileged to pursue my passion in planning, while inspired by the daily interactions of an inquisitive toddler, ready to engage the world.

I would like to personally thank my faculty advisor, Nina-Marie Lister, Associate Professor and Graduate Programme Director for the School of Urban and Regional Planning at Ryerson University. You provided a unique lens on urban ecological planning and multi-disciplinary approach in your practice.

Many thanks to my second reader, Sheila Boudreau, Urban Designer at City Planning in the City of Toronto and her colleagues on the Green Streets Team (Shayna Stott, Environmental Planner at City Planning; and Patrick Cheung, Senior Engineer at Toronto Water) for your guidance during my summer planning internship and advice on this MRP.

I wish to express my gratitude to all the individuals who agreed to be interviewed, and the dedicated folks who have been leading the charge across Canada, including Credit Valley Conservation, Toronto and Region Conservation Authority, Green Communities Canada, and to all those involved in the 2016 Roads-and-Runoff Workshop. Thank for sharing your resources and experiences.

I must acknowledge my former colleagues, Kevin Jones (BLOOM) and Tammy Lomas-Jylha (MAH/OCETA), for their mentorship. You challenged me to address gaps through a sustainable process.

Finally, thank you to the instructors and colleagues in the Masters of Planning at Ryerson University. It has been very rewarding, and as promised a collaborative and practical curriculum. You all share my passion for change, through planning and creativity ... and made it fun along the way!

\section{Dedication}

This MRP is dedicated to our son, William. I will plan with a sustainability focus to ensure future generations benefit from the lessons we learn and the best practices we choose to exemplify. 


\section{TABLE OF CONTENTS}

Author's Declaration for Electronic Submission of a MRP ..ii

ABSTRACT iii

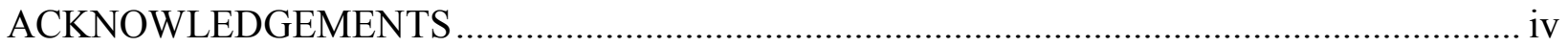

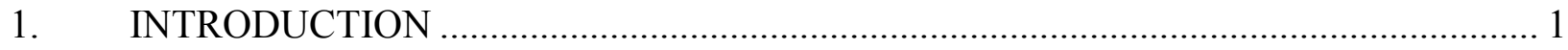

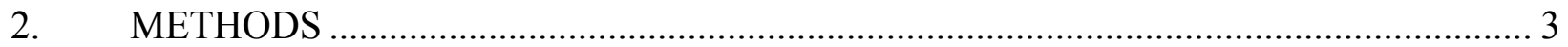

2.1. Secondary Research Methods ........................................................................ 3

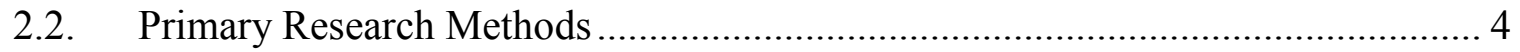

2.3. Analysis of the Research Findings................................................................... 7

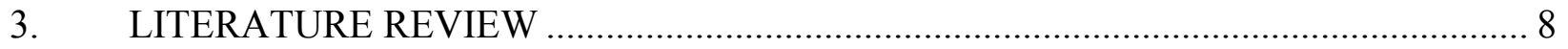

3.1. Conventional Approach to Managing Stormwater ............................................. 8

3.2. Environmental Significance to Ontario Municipalities ................................... 11

3.3. Policy Framework in Ontario......................................................................... 13

3.4. Financing Options on GI Programs for SWM ................................................. 23

3.5. Precedent from U.S. Cities with Green Infrastructure Programs........................ 30

4. STATE OF PRACTICE FOR GSI POLICIES \& PROGRAMS ................................... 31

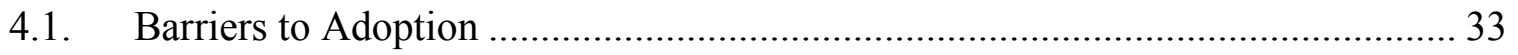

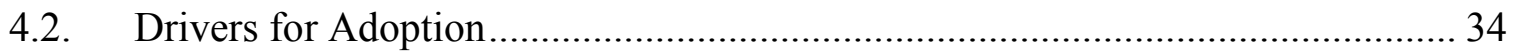

4.3. Analysis of Interviews on Municipal GSI Policies \& Projects........................... 39

4.4. Best Practices \& Lessons Learned ................................................................... 48

5. CONCLUSION \& RECOMMENDATIONS ..................................................... 50

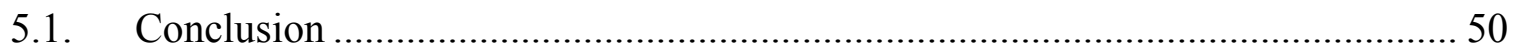

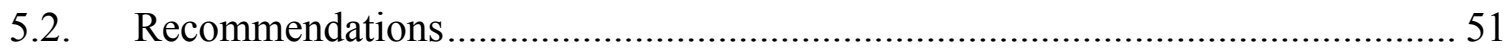

Appendix A: Ethics Approval for Research .................................................................. 53

Appendix B: Consent Agreement \& Correspondence with Interviewees ............................... 54

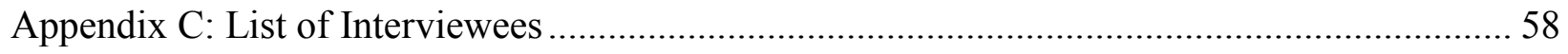

Appendix D: Interview Questions for Municipal Government Representatives ........................ 59

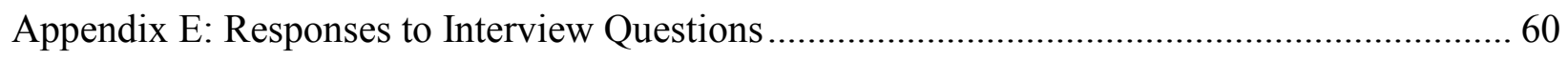

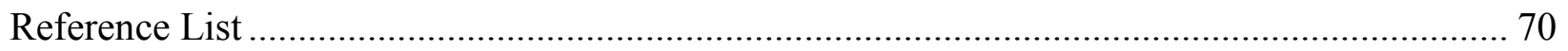

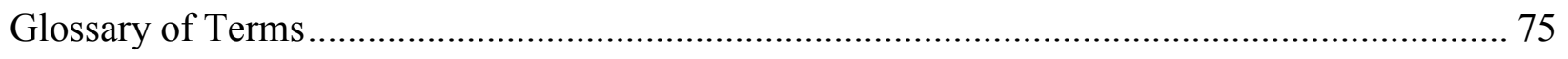




\section{List of Figures}

Figure 1: Stormwater Infiltration \& Runoff on Rural \& Urban Surfaces ................................................. 1

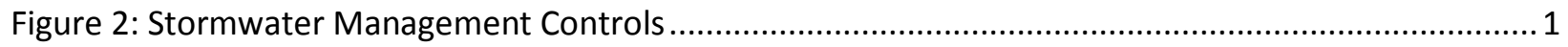

Figure 3: Storm sewer upgrades for areas with basement flooding …................................................. 8

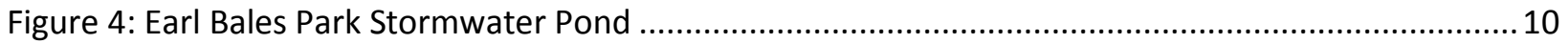

Figure 5: Impacts from the July 8, 2013 Storm in Toronto ............................................................... 11

Figure 6: ROW impact of July 8, 2013 storm in Mississauga .............................................................. 11

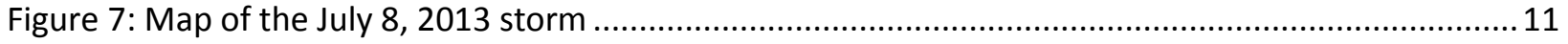

Figure 8: Reported Flooded Basements in Toronto from storm events (2000-2013) ............................ 12

Figure 9: Evolution of Stormwater Management Practice and Policy in Ontario.....................................13

Figure 10: Relationship between municipal land use and watershed planning .....................................2 20

Figure 11: Municipal Departments Involved in SWM Master Planning ...................................................22

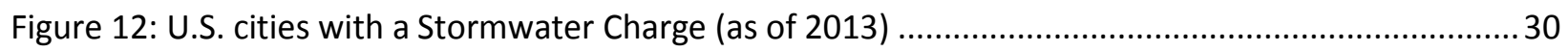

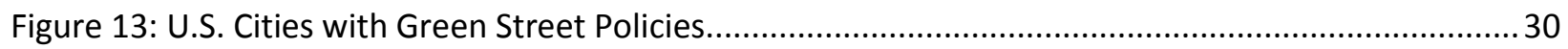

Figure 14: Conventional end-of-pipe vs LID Strategy for sub-division................................................... 31

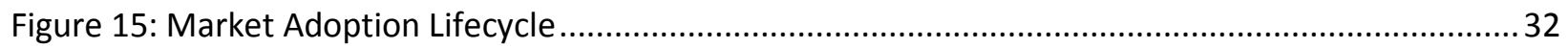

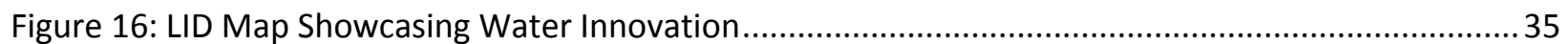

List of Tables

Table 1: Factors that contribute to Issues with conventional Stormwater Infrastructure....................... 9

Table 2: Strategies to reduce the volume and impact of stormwater (Ontario Great Lakes Strategy)...... 18

Table 3: Kitchener Stormwater Charge Classification (2015 rate) .......................................................... 28

Table 4: Barriers to Adoption of Green Stormwater Infrastructure .......................................................33

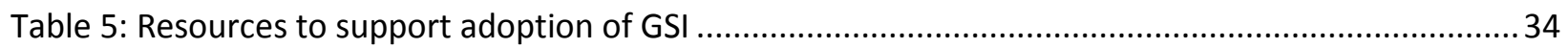

Table 6: Life Cycle Cost for Low Impact Development Installations........................................................36

Table 7: GSI Source Control Options with Attributes and User Applications ............................................. 37

Table 8: Municipal Drivers for Adoption or Piloting GSI for SWM (Interviewee Responses) ..................... 40

Table 9: Types of GSI Projects Adopted by Municipalities for SWM (Interviewee Responses)..................41

Table 10: Examples of Municipal Drivers for Adopting a Stormwater Charge ....................................... 44

Table 11: GSI Policies, strategies, \& tools for Municipal adoption (interviewee responses) .................... 45

Table 12: Example of Polices for GSI through Private Development.................................................... 46

Table 13: Example of Policies for GSI Education \& Training .............................................................. 47

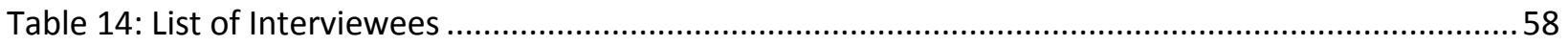




\section{INTRODUCTION}

Large urbanized municipalities in Ontario are currently faced with a growing concern of how to manage rain where it falls and the associated stormwater runoff. The conventional approach has

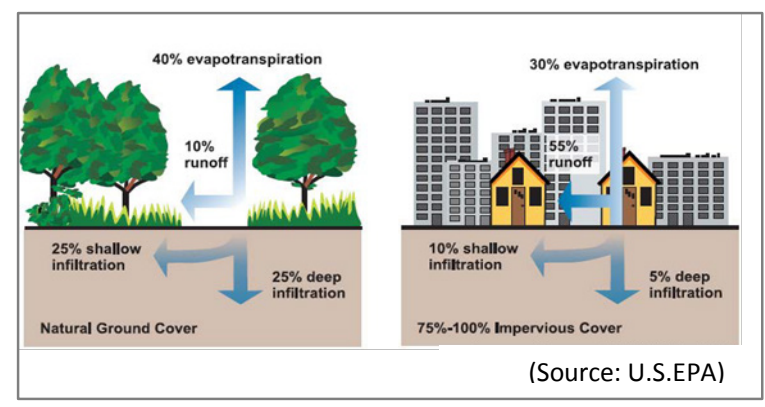

Figure 1: Stormwater Infiltration \& Runoff on Rural \& Urban been to manage and treat stormwater as part of a wastewater service ${ }^{1}$, however this approach has experienced greater risks associated with more frequent flooding due to climate change and intensification that increases the amount of impermeable surface areas, resulting in a significant reduction of infiltration and retention capacity (Figure 1). Source controls (Figure 2) for Stormwater Management (SWM) are recognized for their importance with on-site stormwater infiltration, retention, treatment, and ability to mimic and restore natural systems, otherwise know as green infrastructure (GI). A growing number of Ontario municipalities are adopting green stormwater infrastructure (GSI) through Low Impact Developments (LID) ${ }^{2}$, which maintain the water balance by retaining rain where it falls and filtering stormwater. Overflows are typically conveyed through clean water collector/infiltration systems directing stormwater to naturalized waterways such as rain gardens and stormwater ponds. The manner in which new GSI projects and programs are being adopted, funded, implemented and managed is challenging. This report identifies best practices through a change of practice for planning policy in the public Right-of-Way (ROW) and on private sector installations through new developments (Blakelock \& Maynes, 2016).

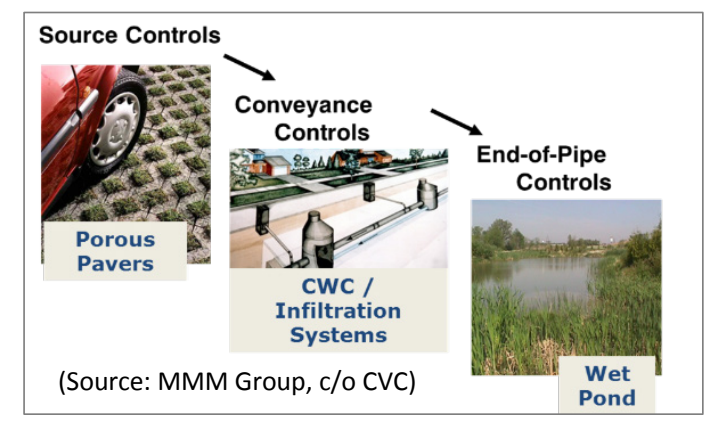

Figure 2: Stormwater Management Controls

\footnotetext{
${ }^{1}$ In Ontario, wastewater services are provided to Residential; and Industrial, Commercial and Institutional (ICI) sector customers. The quality of wastewater discharged into the municipal sewage system is controlled through municipal sewer-use By-laws. (Ontario Municipal Benchmarking Initiative, 2014)

${ }^{2}$ The terms Green Infrastructure (GI), Green Stormwater Infrastructure (GSI), and Low Impact Development (LID) are used interchangeably in this paper for stormwater management, which are defined in the Glossary of Terms.
} 
CHAPTER 1: INTRODUCTION

STORMWATER MANAGEMENT: ONTARIO MUNICIPAL POLICIES FOR GREEN INFRASTRUCTURE

The issue of SWM is complicated with aging infrastructure, the need to accommodate growth through new development and intensification that increases the amount of impermeable surface areas. Human-influenced climate change has been tied to the increased frequency of major storm events in the Greater Toronto and Hamilton Area (GTHA) which is resulting in localized and riverine flooding (Toronto and Region Conservation Authority, 2013). To compound the issue, many larger and older municipalities are faced with an infrastructure deficit as they are unable to keep in pace with the higher density of their urban cores and new growth on former green spaces. Mitigation of these issues will require replacing, repairing and constructing additional infrastructure. The emerging approach of SWM through GI in municipalities across North America promotes sustainability and efficiency, and the adoption of programs like Green Streets can also support active transportation and complete streets ${ }^{3}$. New municipal finance approaches for stormwater management are required and to be more fair to water users/consumers, while providing accountability and transparency and a source of funding necessary for continued and sustainable GSI installations, operations, and maintenance.

\section{Research Objectives}

The findings of this study can be used as a rationale to support the financing, operations and management for local SWM in the public ROW and on private developments through GSI.

1st. To reveal the state of practice in Ontario for green stormwater infrastructure through the issues, supporting policies, and financial tools available to finance GSI in Ontario municipalities;

2nd. To highlight and reveal best practices and lessons learned from the experiences of municipal and private development practitioners through reflective practice interviews; and

3rd. To provide recommendations that will support the next steps to GSI policies and programs from the patterns that emerge through this study.

\footnotetext{
${ }^{3}$ The terms green streets, active transportation and complete streets are defined in the Glossary of Terms, and have been provided to illustrate the multi-purpose objectives that can be achieved through redesign of the right-of-way.
} 


\section{METHODS}

This section describes the methodology and associated research methods followed to fulfill the research objectives. A knowledge base of GSI studies was built through secondary and primary research in order to uncover the underlying reasons and challenges with adopting and implementing GSI.

Qualitative Research methods were employed, following a typical non-linear path of reframing the research questions through collecting data, interpreting and analysing the results, which required additional data collection to refine the scope (Neuman \& Robson, 2015, p. 82). This approach was highly effective for gaining a more comprehensive understanding of the subject and it allowed the integration of emerging knowledge on GSI. The research objectives (Chapter 1) emerged from general questions on how to plan for SWM, through successive graduate research studies conducted from 2014 to 2015 . The research methodology consisted of a Literature Review; a Summer Internship, Site Visits of GSI pilot demonstrations; attending a Sector Workshop on GSI; and Qualitative Interviews.

\subsection{Secondary Research Methods}

The Literature Review demonstrated a familiarity with the body of knowledge on GSI and revealed major issues of SWM and barriers to GSI policy adoption (Neuman \& Robson, 2015, p. 65). The review included findings from published books, periodicals including scholarly journals and dissertations, government documents, policy reports, and information on the internet. The data was synthesized to reveal the path of current research and the direction the practice is moving towards. The methodology was structured to frame the issues by first providing the context in which the conventional approach to SWM are failing to address issues associated with urbanization and climate change, and to uncover the environmental impacts faced by society and the environment. The literature review laid out the Provincial legislative framework for stormwater and GSI, which helps to understand what financing options are available to a municipality when trying to adopt a GSI program. Precedents from U.S. cities with GSI and Green Streets policies demonstrates the adoption of new financing models and policies. 
CHAPTER 2: METHODS

STORMWATER MANAGEMENT: ONTARIO MUNICIPAL POLICIES FOR GREEN INFRASTRUCTURE

Knowledge Base through Previous Research

My interest in SWM can be traced back to my undergraduate degree in Environmental Science, where I participated in field sampling, analysis of stream flow, and witnessed the effects of urbanization through riverine flooding. As part of my graduate studies at Ryerson University, I undertook a number of cumulative studies that framed my understanding of the issues. In the fall of 2014 , I prepared a "State of the Benchmark Report: SWM Source Controls through Policy in the City of Toronto" focusing on the Toronto Green Standards (City of Toronto, 2013) for new development applications; and an "Evaluation of Permeable Paving Solutions for SWM" to plan more sustainably. I also conducted a study of "Municipal Finance Models in Ontario to implement new GSI Programs", and through a Studio project, our team proposed solutions for a Riverfront Park in the Lower Don River Valley, which will help address concerns with flooding, water balance, and water quality (Abramowicz, et al., 2015).

This cumulative secondary research revealed a potential knowledge gap for municipal SWM policies in the public ROW and private developments through GSI, which framed the three research objectives. The qualitative research method, allowed for exploring different perspectives on GSI policies and strategies, from the academic to practical realm, and from a regulatory, to public and private lens (Neuman \& Robson, 2015, p. 81).

\subsection{Primary Research Methods}

Primary research was undertaken during a Summer Planning Internship at the City of Toronto's City Planning Department (2015), where I conducted qualitative interviews on the operations of GSI programs in U.S. cities, which supported the ongoing development of a City of Toronto "Green Streets Program" in the ROW. Site Visits were conducted of GSI installations through pilot demonstration projects in the Cities of Mississauga (2015) and Toronto (2016) to visualize and contextualize the setting in which GSI are implemented. In addition, I attended a sector workshop, "Roads and Runoff: Implementing Green Streets in the Greater Golden Horseshoe" (Mississauga, ON, on March 1, 2016), 
CHAPTER 2: METHODS

STORMWATER MANAGEMENT: ONTARIO MUNICIPAL POLICIES FOR GREEN INFRASTRUCTURE

which included presentations on leading municipalities in southern Ontario with GSI policies and practices (Green Communities Canada, 2016). A primer to the workshop, a "Workshop Discussion Paper to the Roads and Runoff Workshop: Implementing Green Streets in the Greater Golden Horseshoe", supported the findings from the literature review by identifying key barriers and potential solutions to be explored for adopting Green Streets policies and practices (Blakelock \& Maynes, 2016).

Qualitative Interviews utilized questions that allowed the interviewees to reflect upon their practice and experience before providing a response, with the questions being distributed one-week prior to the interview. The format and style selected were typical to qualitative interviews, as an open styled conversation between the interviewer and interviewees, not necessarily following the order of questions provided ahead of time, but allowing for an opportunity to explore responses and exchange ideas and knowledge (Neuman \& Robson, 2015, pp. 269-274). The interviews were conducted with key staff from five Ontario municipalities and a sample of private-sector developers representing projects with GSI in each of the cities (Appendix C: List of Interviewees). The workshop and literature review identified main actors in the public and private realm implementing GSI programs to be interviewed, referred to as purposive sampling. Snowball sampling, a peer referral technique, was utilized to recruit additional interviewees. Telephone Interviews were preferred due to their flexibility with scheduling, allocating one-hour for each interview (Neuman \& Robson, 2015, pp. 136-138, 184).

The interview questions were categorized into key themes that corresponded to the literature review, through seven semi-structured questions (Appendix D: Interview Questions for Municipal Government Representatives), which framed key elements of GSI policies such as: the types of SWM reviewed and/or implemented; the main drivers for adopting or piloting a GSI program; the policies, strategies and/or tools available; the potential for interaction between private and public space; the tools used to monitor and manage GSI installations; the outreach, education and training provided; and the best practices and lessons learned based from their practical experiences with GSI. 
CHAPTER 2: METHODS

STORMWATER MANAGEMENT: ONTARIO MUNICIPAL POLICIES FOR GREEN INFRASTRUCTURE

\section{Ethics in Research}

The research method and interviews followed protocols of Ryerson University's Research Ethics Board (Appendix A: Ethics Approval for Research). This followed the $2^{\text {nd }}$ edition of the Tri-Council Policy Statement: Ethical Conduct for Research Involving Humans (TCPS 2) which guides research methods and approaches for conducting qualitative interviews (Government of Canada, 2014).

In addition, the approach taken for this planning research sought to adhere to the Ontario Professional Planners Institute (OPPI) Professional Code of Practice 4 and the Canadian Institute of Planners (CIP) Statement of Values ${ }^{5}$ (Ontario Professional Planners Institute , 2012).

\section{Limitations of Research Methods}

The interviews were not audio-recorded as the time required for transcribing became a constraint. This was not considered an issued due the quantity and quality of data available through the literature review or as provided by the interviewees as supporting documentation. Coding of the interviewee responses was not employed, due to the semi-structured and qualitative responses.

The internet offered a quick method to conduct scans of current practices and to find out what is emerging/new in a particular field. Potential limitations and concerns of using the internet for research are well documented, such as reliability and quality control (i.e., is the data from a credible source? has it been peer reviewed?). Keeping that in mind, the internet was used as a supporting tool to access documents (reports, publications, etc.) and for identifying potential resources that could be further researched through more conventional academic means.

An initial concept was to quantify the type of SWM installed based on information obtained

\footnotetext{
${ }^{4}$ The OPPI Professional Code of Practice states that members must practice in an ethical and responsible manner, which takes into account the Planner's Responsibility to the Public Interest; to Clients and Employers; and to the Profession and Other Members (Ontario Professional Planners Institute, 2015).

${ }^{5}$ The CIP Statement of Values are "to respect and integrate the needs of future generations; to overcome or compensate for jurisdictional limitations; to value the natural and cultural environment, to recognize and react positively to uncertainty, to respect diversity, to balance the needs of communities and individuals, to foster public participation; and to articulate and communicate values" (Ontario Professional Planners Institute , 2012).
} 
CHAPTER 2: METHODS

STORMWATER MANAGEMENT: ONTARIO MUNICIPAL POLICIES FOR GREEN INFRASTRUCTURE

through the interviews (e.g. site locations, implementation-logistics, site constraints, environmental factors, financial incentives \& costs, and market factors), which would have been reflected through case studies for each of the five municipal programs explored (Kitchener, Mississauga, Toronto, Vaughan, and Waterloo). However, as GSI in Ontario is still at an early stage, many municipalities were unable to provide quantitative metrics on all the installations in both the public and private realm.

\subsection{Analysis of the Research Findings}

The State of Practice with GSI policies and practices were examined to uncover lessons learned and reveal best practices for other municipalities. The research method was structured to present the rationale of GSI by defining the environmental issues of SWM, revealing the supporting legislative framework, finance options, and precedents. A summary of the interviewee responses was presented through the state of practice. GSI policies were conceptualized through interviews, and patterns that emerged were used to identify operationalization of practices (Neuman \& Robson, 2015, p. 112).

An Analysis of the Research Findings mapped the data (i.e., interview responses) in a matrix format (Tables 8 to 12) that compared the type of GSI projects and approaches used (e.g., different LID technologies, municipal programs, and financial policies), main drivers for adoption, and municipal programs and policies that are in place or are being considered. A comparison of voluntary performance measures against mandatory standards from the municipalities revealed what measures are being implemented beyond compliance, and which ones were potentially more attractive to the private developers considered as environmentally-friendly or sustainable focused.

Recommendations revealed best practices and lessons learned, highlighting experiences of GSI policies and installations that will support the next steps for implementing and adopting a green stormwater infrastructure policy and program. 


\section{LITERATURE REVIEW}

\subsection{Conventional Approach to Managing Stormwater}

In most urban areas, roadways are the main conduit for rainwater runoff, which is generally conveyed through a system of storm drains and subsurface sewers, with outflows discharging directly to nearby waterbodies such as rivers, lakes, and natural ponds. For newer developed areas, mainly in subdivisions, rain is conveyed to engineered stormwater retention ponds designed to hold the water, which allows for infiltration, evapotranspiration, and biological treatment before discharged downstream. In older, rural areas, the conventional and most cost effective approach are simple roadside ditches that retain and convey runoff into water bodies downstream. However, in the older urban cores of major cities stormwater is treated as wastewater like sanitary sewage where storm drainage feeds into a combined sewer overflow (CSO) system, and is usually seen as a municipal engineering water and wastewater services (EcoJustice, 2008).

Many of these conventional systems were installed as cities grew in Southern Ontario in the late 1950s to 1970s (Di Gironimo, 2016). They are aging and were not designed to accommodate the increased volumes due to dense and impermeable surfaces of urban cities, which are amplified by extreme weather events due to climate change. Where flooding is a major issue, due to burst pipes and volume constraints, the

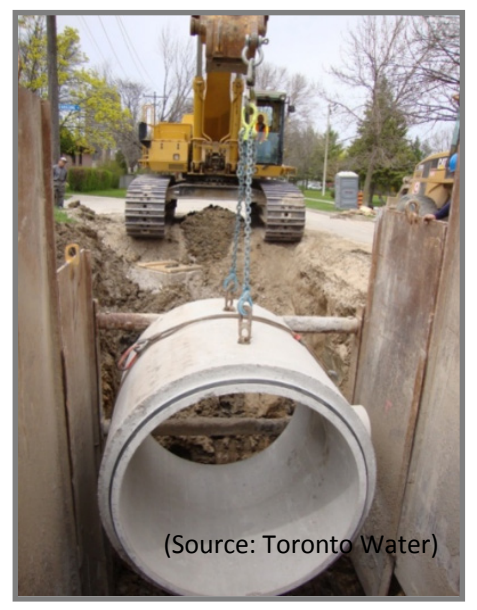

Figure 3: Storm sewer upgrades for areas with basement flooding

grey infrastructure must be replaced (Figure 3). In this scenario the cost of services for water and wastewater increases directly with distance from the urban core and inversely with the density of development, with the costliest areas to service at the outlying, low-density developments (Slack E. , 2006). With the conventional approach, the often used financial model for stormwater management is to include it in the calculation of sanitary wastewater (i.e., a percentage of the metered water user fee), which is supposed to adequately account for collection and treatment as wastewater (Tassonyi, 2002). 
This approach has a number of flaws when dealing with rainwater. Primarily among these is that it assumes that the users of water are primarily responsible for all types of wastewater, including stormwater, and that the volume of water use is the same as that of stormwater entering the system. This financial model not only penalizes the users with high water usage typically found in the heart of urban cores such as high-rise developments, but does not adequately address the source of rainwater runoff, which is the impervious surfaces that feeds stormwater outfalls and CSO systems. An underlying rationale for using this system could have been that a single-system for sewer and stormwater was at one time adequate to handle the design of the population when constructed, with plant-safety by-pass controls in the instance of a 100 -year storm to avoid major infrastructure damage. Municipalities with a CSO system face many issues when looking to update a combined sanitary sewer line with a dedicated stormwater sewer. Replacing the infrastructure is complicated by many factors (Table 1 ) and costs more on urban infill than in a greenfield development (Ontario Municipal Benchmarking Initiative, 2014).

Table 1: Factors that contribute to Issues with conventional Stormwater Infrastructure

Aging Infrastructure: The condition of wastewater collection system is poor in most older municipalities with frequent burst pipes and high maintenance costs and limited resources.

Government Structure: Single-tier service providers with jurisdiction over the wastewater system vs. two-tier system where the responsibility for wastewater service is divided between the local municipalities and the Regional municipality.

Policy and Practices: Frequency of wastewater collection system, maintenance activities, collection system age, condition and pipe material, and enforcement of supporting policies.

Supply and Demand: Respective volume of wastewater generated relative to the total system demand. The quantity of wastewater flows from Industrial, Commercial and Institutional (ICI) sectors relative to residential demand.

Treatment Plants (end-of-pipe): Number, size and complexity of the wastewater collection systems and treatment plants operated.

Urban Density: Proximity of pipes to other utilities increases the cost for infrastructure repair and replacement. 
In the evolution of SWM, a shift occurred from the pipe-and-treat approach as wastewater to engineer stormwater ponds built primarily in new sub-division developments, which conveys local water runoff into a retaining pond for settling and biological treatment before being discharged downstream (Ministry of the Environment, 2003, pp. 4-51). This approach was considered an ideal solution due its seeming low-maintenance approach and design simplicity that separates stormwater runoff. However,

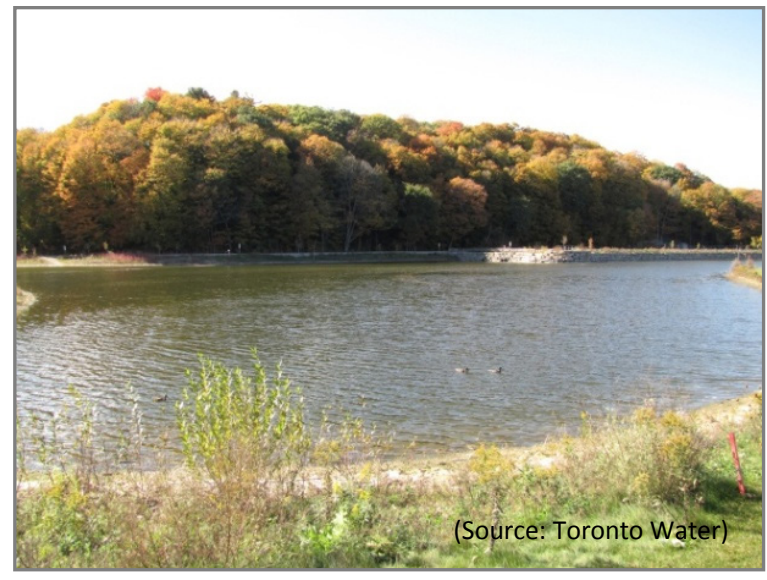

Figure 4: Earl Bales Park Stormwater Pond
SWM ponds are generally limited to new large-scale developments that can accommodate the space and are often planned as part of a new sub-division. It is very complicated to retrofit in a built up area, which typically faces scrutiny from the existing community, such as the Earl Bales Park SWM pond (Figure 4) introduced in fully built-up area (Di Gironimo, 2016).

In addition, there are significant challenges associated with maintenance of SWM ponds, as roads convey sediments and contaminants from vehicles and households. In a 2013 Staff Report to the TRCA board, it was noted that a large number of the ponds have never been dredged, and many are nearing or have reached their maximum sediment design capacity. Too much sediment reduces their ability to efficiently control floods and keep pollution out of the downstream waterways. In 2013, seven ponds out of 84 in Toronto were identified as a priority for high sediment volumes with two scheduled to be drained/dredged at a cost of $\$ 740,000$ or higher. Staff indicated that actual cost of maintenance for sediment ponds vary greatly, because disposal methods and costs vary based on any contamination found within each pond (Adler, 2013). Although sediment ponds are preferable due to capacity if space permits, these costs are relevant when comparing the life cycle costs against other LIDs (Table 6). There is also a balance required between function and reduction of the redevelopment potential, especially in cities across Ontario that have a strong real estate market. 


\subsection{Environmental Significance to Ontario Municipalities}

The cumulative effects of stormwater runoff exacerbate existing problems. These include:

increased flooding risks (basement and riverine); river bank and bed erosion; increased turbidity; aquatic habitat destruction; changes in the water balance and stream flow regime; infrastructure damage with flooding and overloaded systems; and contamination of natural waters from urban pollutants ${ }^{6}$ through stormwater outfalls and combined sewer overflows (CSO) that mixes raw human wastewater. Road runoff is associated with approximately $80 \%$ of stormwater pollutant loading (Credit Valley Conservation, 2014). The resulting pollution affects ecosystems, recreational uses, and drinking water.

Flooding is the most significant and visible impact to the pubic, as illustrated by the major storm event on July 8, 2013 (refer to Figures 5-7), which affected the Cities of Toronto, Mississauga, Brampton, and parts of Vaughan, with a peak of over $130 \mathrm{~mm}$ at its epicentre, resulting in property damage estimated at $\$ 940$ million in Toronto
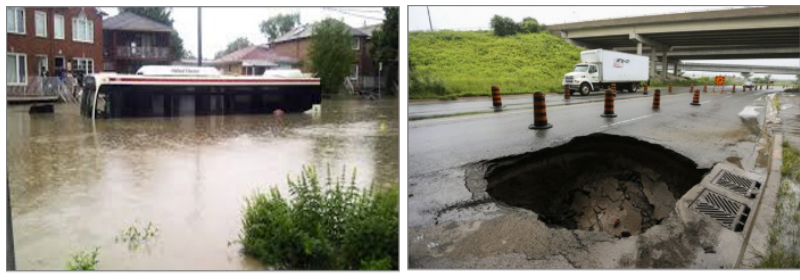

(Ontario's Climate Change Strategy, 2015, p. 5).

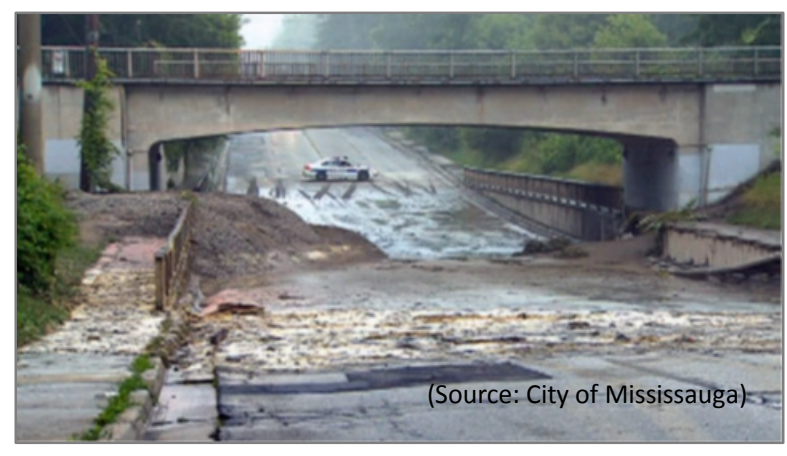

Figure 6: ROW impact of July 8, 2013 storm in Mississauga
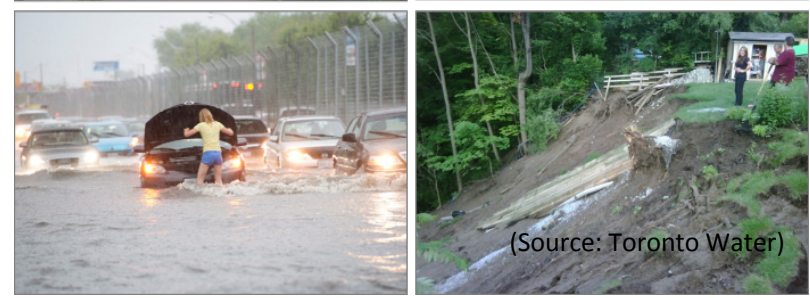

Figure 5: Impacts from the July 8, 2013 Storm in Toronto

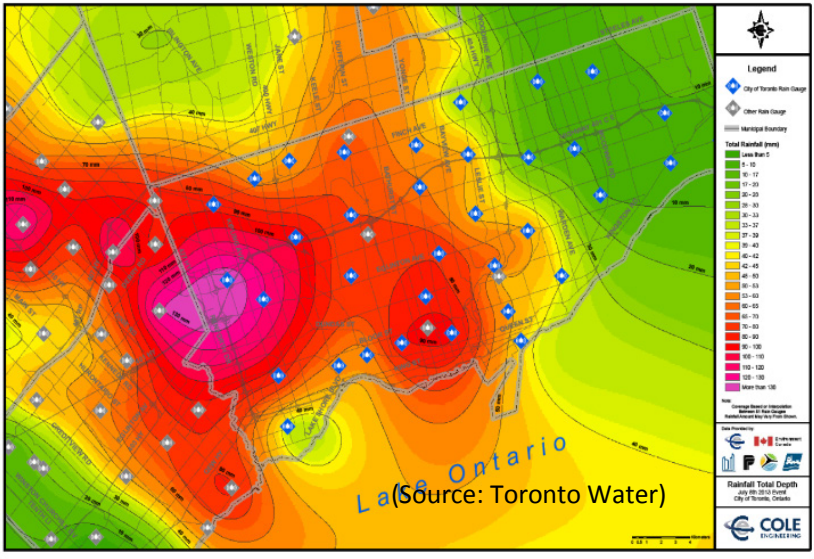

Figure 7: Map of the July 8, 2013 storm

\footnotetext{
${ }^{6}$ Urban pollutants in stormwater runoff typically include: pesticides, road salts, heavy metals, oils, grease, bacteria, sediment, and other harmful pollutants including thermal heat from stormwater discharge (Toronto and Region Conservation Authority, 2012)
} 
The GTA has seen a significant rise of basement flooding ${ }^{7}$ over the recent years attributed to frequent high-intensity rainfalls and the inability to retain, infiltrate and manage the runoff. To further illustrate the extent of major storm events on in Toronto, reported complaints of basement flooding ${ }^{8}$ were mapped (Figure 8) from the 2000 to 2013.

Riverine and basement flooding affects municipal infrastructure (roads, sewer lines, and transit),

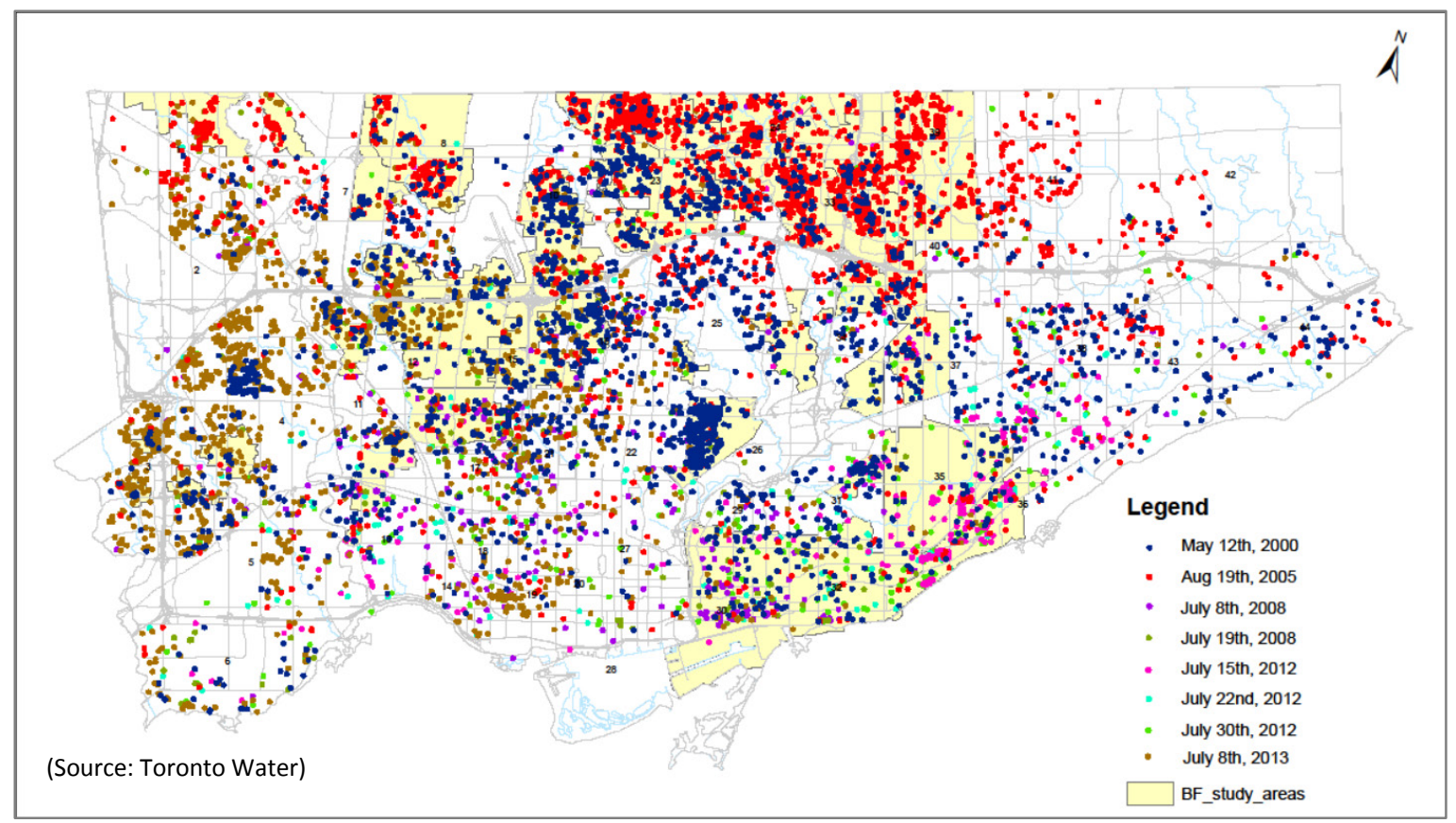

Figure 8: Reported Flooded Basements in Toronto from storm events (2000-2013)

residences, and waterway quality. The number of reported flood events emphasises the problem associated with the traditional approach of relying on stormwater retention ponds, which continue to exceed their designed capacity for volume of water and sediment as urban redevelopment continues to increase the impervious hardscape area of the city. This data shows that conventional pipes and ponds are not meeting targets for quantity and quality control, and new measures to support managing rain where it falls is required in southern Ontario.

\footnotetext{
${ }^{7}$ In the City of Toronto, there has been an increase in reported flooding, with over 10 major events form the June 28 to July 8, 2013 major rainfall events. (City of Toronto, 2013).

${ }^{8}$ In Toronto, over 4,700 flooded basements were reported from June 28 to July 8, 2013 following major rainfall events. (City of Toronto, 2013).
} 


\subsection{Policy Framework in Ontario}

Water is integral to supporting the people of Ontario and the protection of surface and ground water quality and quantity is of great significance to the Government of Ontario. High-level policies provide the legal framework and direction for land use planning and stormwater management in Ontario such as the Planning Act, the Provincial Policy Statement, Conservation Authorities Act, and Environmental Protection Act. It is of no surprise that there exists numerous Provincial policies and guidance documents that have evolved over time (Figure 9) and are continuing to emerge (Credit Valley Conservation; Toronto and Region Conservation Authority, 2011), which will introduce additional policies to address barriers and gaps for the management of rain where it falls.

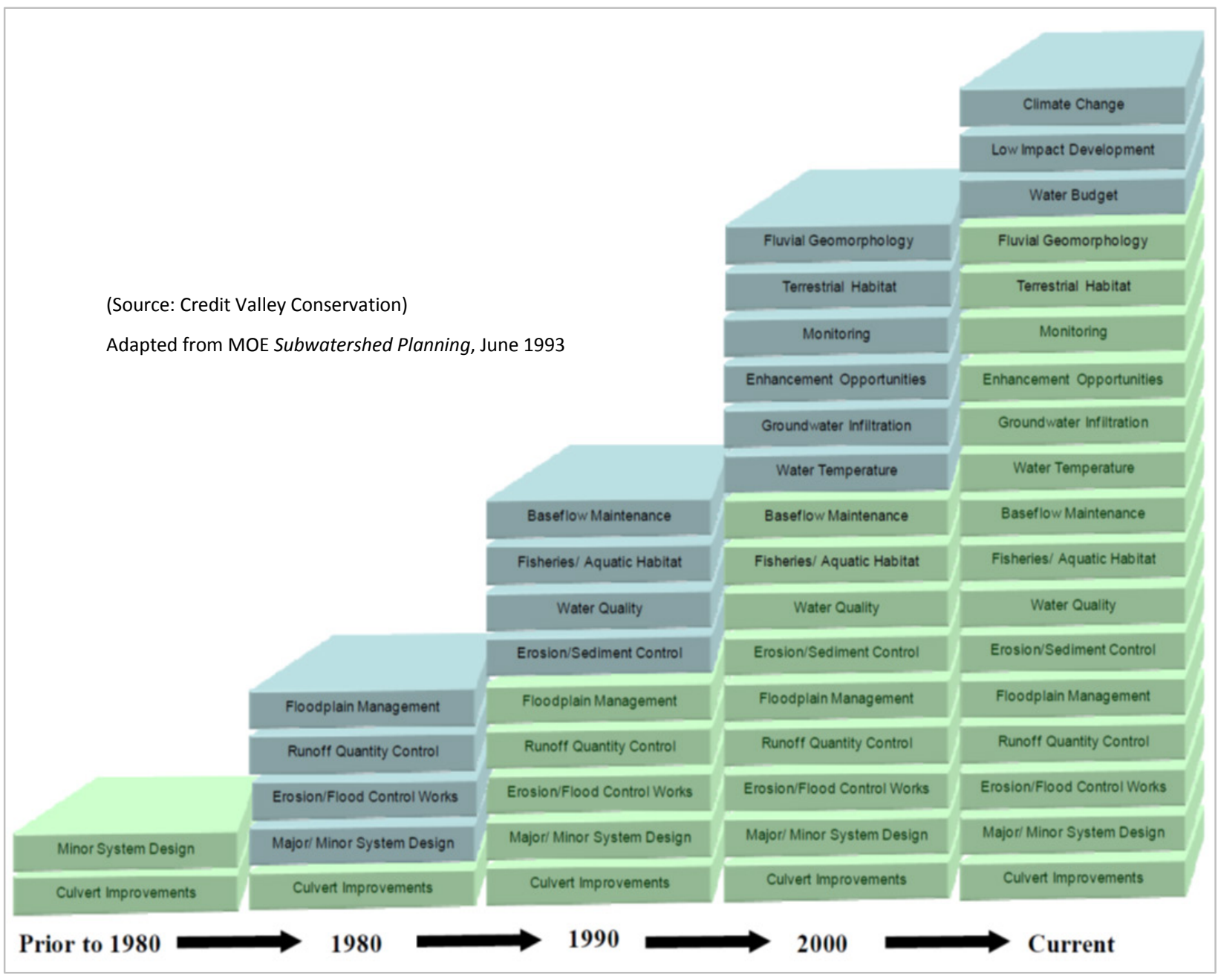

Figure 9: Evolution of Stormwater Management Practice and Policy in Ontario 
CHAPTER 3: LITERATURE REVIEW

STORMWATER MANAGEMENT: ONTARIO MUNICIPAL POLICIES FOR GREEN INFRASTRUCTURE

The following Provincial policies (Acts, Plans, \& Strategies) are relevant to stormwater management planning and the adoption of GSI, which are presented with their relevant sections.

The Conservation Authorities Act, 1946 is a powerful legislative framework that is historical and set a precedent for watershed management related legislation. The CA Acts supports local and regional implementation of GSI as it mandates Ontario's Conservation Authorities (CAs) to prevent, eliminate, or reduce the risk to life and property from flooding and erosion, and to encourage the protection and regeneration of natural systems, which has shaped current SWM practices. Ontario's CAs work with municipal, provincial, and private sector partners to maintain the safety, quality, and sustainability of the water resources within our communities. CAs also have Memoranda of Understanding (MOUs) with their partner municipalities to ensure that the tenets of the Provincial Policy Statement are upheld, and that no adverse effects to significant natural features result from development applications approved through the Planning Act. Interestingly, TRCA was established in 1957 as the Metropolitan Toronto and Region Conservation Authority (MTRCA) following flooding from Hurricane Hazel in 1954.

The Planning Act, 1990 sets rules for land use planning in Ontario and describes how land uses may be controlled and who may control them. It considers the provincial interests, such as protecting and managing our natural resources; preparing Official Plans $(\mathrm{OP})^{9}$; and regulating land use through zoning by-laws and minor variances. Section 1.1 describes the purposes of this Act, which includes the promotion of sustainable economic development in a healthy natural environment; while Section 2 requires the responsible authority to provide protection of ecological systems, including natural areas, features and functions. It also calls for the promotion of development that is designed to be sustainable (Ministry of Municipal Affairs and Housing, 1990).

\footnotetext{
${ }^{9}$ OP are required to be consistent with the PPS, which is driving municipal policy change as "green infrastructure" is now included in the PPS 2014. OP policies are defendable at hearings with the Ontario Municipal Board, where clarity on policy issues are critical to land use decisions (Boudreau, S., personal communication, April 2016)
} 
CHAPTER 3: LITERATURE REVIEW

STORMWATER MANAGEMENT: ONTARIO MUNICIPAL POLICIES FOR GREEN INFRASTRUCTURE

The 2014 Provincial Policy Statement (PPS) provides clear policy direction on land use planning to promote strong communities, a strong economy, and a clean and healthy environment. The PPS may be complemented by provincial plans or by locally-generated policies regarding matters of municipal interest. It includes policies on key issues that affect our communities, such as the efficient use and management of land and infrastructure; and the protection of the environment and resources. The PPS has a number of relevant sections that pertain to SWM, GI, and LID, in particular subsection 1.6.2 that recommends that planning authorities promote green infrastructure to complement infrastructure, while subsection 1.6.6.7 recommends that planning for stormwater management consider contaminant loads, water balance, erosion, human health and safety, property damage, the function of vegetative and pervious surfaces, and the attenuation and re-use of stormwater through low impact development. Subsection 2.2.1 further requires that planning authorities provide protection, improvement and/or restoration to the quality and quantity of water on a watershed scale. This could be achieved through long term planning, and development through integrated ecological designs, vegetative and permeable surfaces that considers impacts (Ministry of Municipal Affairs and Housing, 2014).

The Growth Plan for the Greater Golden Horseshoe, 2006 (Growth Plan), is adopted under the Places to Grow Act, 2005. The Growth Plan envisions intensification of existing built-up areas with a focus on urban growth centres, intensification corridors, major transit station areas, brownfields and greyfields. Section 3 provides guidance for infrastructure planning and decisions that will accommodate forecasted population and economic growth, with one of the three key areas being water and wastewater systems. It recommends that municipalities co-ordinate their planning for potable water, stormwater, and wastewater systems to ensure that water quality and quantity is maintained or improved under subsections 3.2.5(6); and further encourages the implementation and support of innovative stormwater management actions as part of redevelopment and intensification under subsection 3.2.5(8). Although Section 6 of the Growth Plan pertains to the Simcoe Sub-area, it 
CHAPTER 3: LITERATURE REVIEW

STORMWATER MANAGEMENT: ONTARIO MUNICIPAL POLICIES FOR GREEN INFRASTRUCTURE

establishes a foundation to align infrastructure investments with growth management on a watershed

scale that will optimize the use of existing, planned and new infrastructure, co-ordinate water and wastewater services, and promote green infrastructure and innovative technologies (Ministry of Municipal Affairs and Housing, 2015).

\section{A 2015 Coordinated Review of the Growth Plan and other related Provincial Plans emphasizes}

the need for increased green infrastructure to protect water resources and adapt to climate change (Ministry of Municipal Affairs and Housing, 2015). Participant feedback and recommendations included:

- Integrating GI and LID strategies and materials in construction and development projects to support the development of resilient communities (e.g., SWM on site to prevent flooding).

- Providing incentives and removing barriers to normalize GI and LID practices.

- Updating SWM infrastructure and design to incorporate and prepare for more severe weather events brought on by climate change.

A number of policies centred around the water quality of the Great Lakes providing a legislative framework for not only provincial and local governments in Ontario, but other key stakeholders including the federal government, international partners, and Great Lakes stakeholders.

The Great Lakes Water Quality Agreement, 2012 reaffirms the 1978 pact between Canada and the United States as a framework to restore, protect and enhance the water quality of the Great Lakes. Measures include prevention, abatement and source control programs (International Joint Commission, 2012). New Provincial Policies are setting the stage to close gaps, such as Bill 66, Great Lakes Protection Act, 2015, and the Canada-Ontario Agreement on Great Lakes Water Quality and Ecosystem Health, 2014 that provides for the health of the Great Lakes-St. Lawrence River Basin.

The Canada-Ontario Agreement on Great Lakes Water Quality and Ecosystem Health, 2014 is an agreement between the Federal and Provincial Governments to supports the restoration and protection of the Great Lakes basin ecosystem, which has been updated since the 1978 Great Lakes Water Quality Agreement. It promotes a number of principles for identifying, reducing or eliminating 
CHAPTER 3: LITERATURE REVIEW

STORMWATER MANAGEMENT: ONTARIO MUNICIPAL POLICIES FOR GREEN INFRASTRUCTURE

harmful pollution (Annex 2) and identifying opportunities to promote innovation (Annex 11) so that the Great Lakes region becomes a key contributor in the growth of the water sector/market, and a global leader in applying innovative technologies, services and solutions to remedy environmental problems (Government of Canada, 2014).

The Great Lakes Protection Act, 2015, provides policies in Schedule 1.2 that requires planning, development, infrastructure and site alteration to include the management of stormwater and wastewater. In addition, it requires the establishment and maintenance of monitoring programs with public progress reports every three years, which will include results of monitoring programs, actions taken and a description of new and emerging issues that will be tabled in the Legislature. The Act requires the Minister to maintain and review the Ontario Great Lakes Strategy every sixth year (Ministry of the Environment and Climate Change, 2015).

The Ontario's Great Lakes Strategy, 2012, sets a vision, goals, and priorities for all the partners of the Great Lakes, including the Government of Ontario, municipalities, First Nations and Metis communities and Great Lakes stakeholders, to help restore, protect, and conserve the Great Lakes. Three sections were noted for their reference to stormwater, and emphasis on GI or LID. The first set of strategies in section (d), emphasized providing assistance to municipalities, developers, the insurance industry, and others with reducing the volumes and impacts of stormwater (represented in Table 2). The second set of strategies, section (e) emphasizes to continue working with municipalities and a broad range of stakeholders on solutions to minimize discharges of untreated sewage from CSO and sewage bypassing a treatment plant during wet weather flows. While, section $(\mathrm{g})$ calls for broad consultations with municipal, water sector and community stakeholders on a Municipal Water Sustainability Plan Regulation under the Water Opportunities Act to promote consistency in the sustainability planning process for water services including stormwater and in the development, measurement and reporting of performance indicators (Ministry of the Environment and Climate Change, 2012). 
1. Support stormwater innovation demonstration projects including GI pilots, monitor their performance and effectiveness, and communicate the results to a broad audience;

2. Update Ontario's municipal wastewater policies to include stormwater, GI, construction runoff and sediment management;

3. Engage conservation authorities, municipalities, and other stakeholders to develop guidance to facilitate and remove barriers to the uptake of innovative source control measures that reduce stormwater volumes, such as GI and LID;

4. Enhance the Province's approach to stormwater approvals with greater emphasis on effluent quality and quantity, in turn driving greater use of innovative source control measures;

5. Seek environmental considerations such as use of LID and use of GI early in municipal planning decisions, so that stormwater is considered as part of project design and approvals;

6. Consult on the development of overarching wastewater policy that includes stormwater, to support the Canadian Council of Ministers of the Environment wastewater strategy; and

7. Promote innovative and cost-effective approaches for managing nutrients in wastewater and stormwater, including GI and LID.

Ontario's Water Opportunities Act, 2010 establishes a framework to drive innovation, create economic opportunities, and promote sustainable water infrastructure and conservation of Ontario's water. Subsection 1.1 states a purpose to foster innovative water, wastewater, and stormwater infrastructure, technologies and services in both the private and public sectors, while Subsection 42.1(1) requires triennial reporting of activities and achievements of those measures (Government of Ontario, 2015), which could be achieved through Municipal Water Sustainability Plans (Ontario's Great Lakes Strategy, 2012, p. 19). Interestingly, the Act was a response to The Water Opportunity for Ontario (2010) report, which presented a compelling vision and a roadmap to leverage expertise in innovative technologies and sustainable water solutions (Bloom Centre for Sustainability; XPV Capital, 2010). 
CHAPTER 3: LITERATURE REVIEW

STORMWATER MANAGEMENT: ONTARIO MUNICIPAL POLICIES FOR GREEN INFRASTRUCTURE

Ontario's Environmental Protection Act, 1990 (EPA) provides protection of the environment,

but does not specify GSI. The EPA does provide a strong rationale to support preventive measures as it prohibits the discharge of any contaminants into the environment which causes or are likely to cause negative effects, and in the case of some approved contaminants requires that they must not exceed approved and regulated limits. It also provides the authority to establish liability to the party at fault for contamination, including corporate officers or directors who have failed to take all reasonable care to prevent unlawful discharges of contaminants into the environment (Government of Ontario, 2016).

Similarly, the Ontario Water Resources Act, 1990 (OWRA), provides for the conservation, protection and management of Ontario's waters and for their efficient and sustainable use to promote Ontario's long-term environmental, social and economic well-being, but also does not specifically refer to GSI. The Act includes stormwater in the definition of sewage, with Section 53 requiring that no person shall use, operate, establish, alter, extend or replace new or existing sewage works except under and in accordance with an Environmental Compliance Approval (ECA) (Government of Ontario, 2015). Some stormwater facilities are exempt from the ECA requirement by Ontario Regulation 525/98 (Ministry of the Environment and Climate Change, 2015, p. 3).

A key implementation tool, the 2003 Stormwater Management Practices Planning and Design (SMPPD) Manual, is a practitioner's guide to stormwater management planning, supported by the Ontario EPA and OWRA. Although lot level source controls (green infrastructure/LID) have been advocated and encouraged since the mid-1990s, in practice wide spread adoption by industry and municipal governments has yet to occur, and has been favouring conventional pipes and stormwater ponds. In response to the rapidly advancing body of knowledge and practice of LID and GI field, an updated manual is currently under development as a "Low Impact Development guidance manual", forthcoming in 2016 (Interpretation Bulletin: Ontario Ministry of Environment and Climate Change Expectations Re: Stormwater Management, 2015). The bulletin clarifies the Ministry's expectations: 
- The ministry's existing policies and guidance emphasize an approach to stormwater management that mimics a site's natural hydrology as the landscape is developed;

- The goal is to control precipitation as close as possible to where it falls by employing lot level and conveyance controls (LID), often as part of a treatment train approach. LID facilities should be sized for optimum control of water quantity (previous soil infiltration capacity guidance from 2003 manual should not be interpreted as a prohibition);

- Existing policies and guidance emphasize the need to use watershed/sub-watershed plans to guide site-specific stormwater management performance criteria. It is expected that a LID stormwater management guidance document will be produced; and

- To reflect the preservation of the natural hydrology in the Environmental Compliance Approval (ECA), and to facilitate uptake of LID SWM practices. It is expected that LID and other source control practices will be reflected in the ministry's ECA process.

\section{Municipal Policies are}

supported by the CAs in

reviewing of their stormwater

management facilities and plans.

The relationship between

municipal land use planning and

watershed planning illustrates a

hierarchal and integrated

planning approach (Figure 10),

and a process to provide input

under legislated mandates

(Credit Valley Conservation;

Toronto and Region

Conservation Authority, 2011).

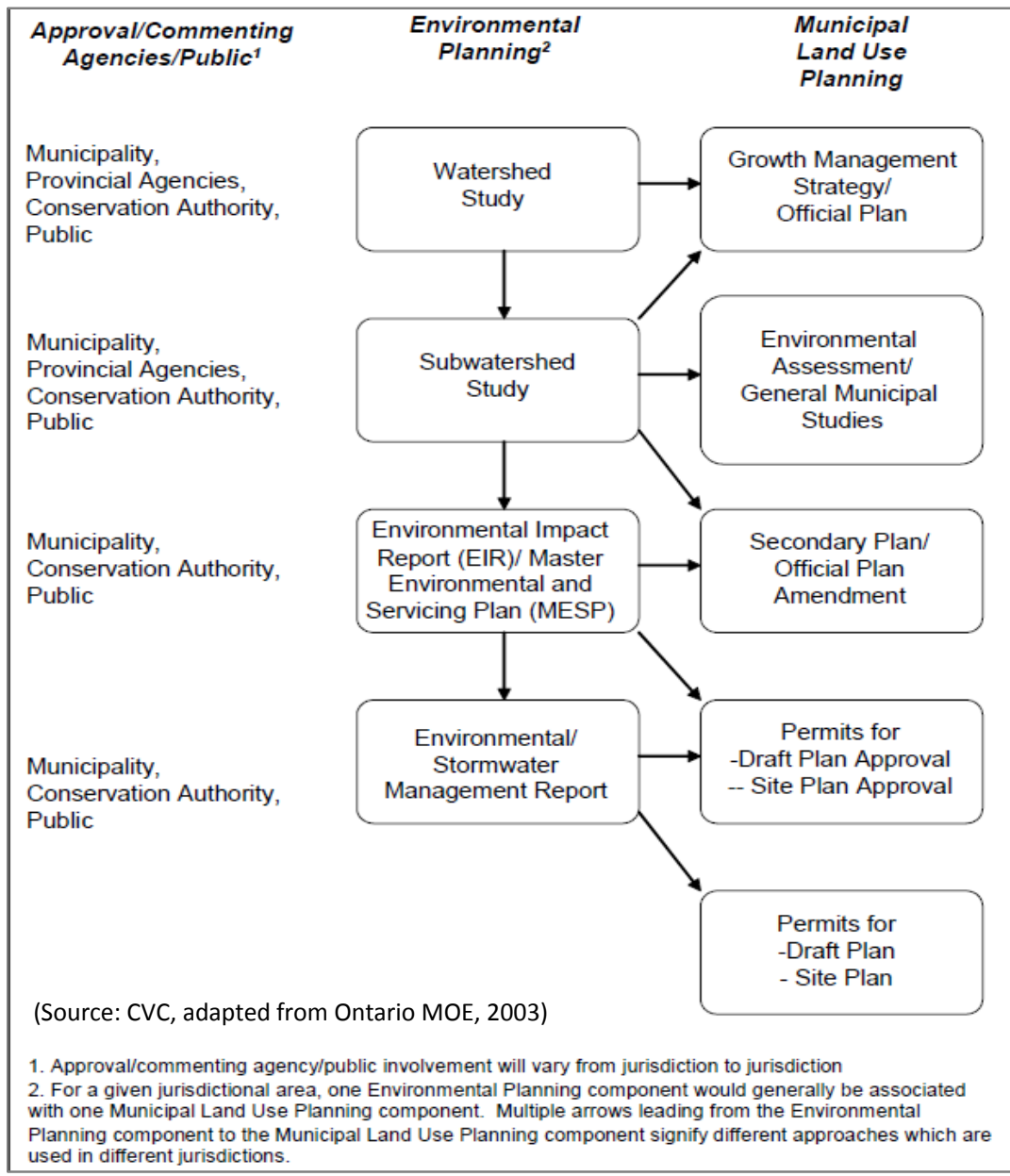

Figure 10: Relationship between municipal land use and watershed planning 
CHAPTER 3: LITERATURE REVIEW

STORMWATER MANAGEMENT: ONTARIO MUNICIPAL POLICIES FOR GREEN INFRASTRUCTURE

A Low Impact Development Stormwater Management Planning and Design Guide outlines a host

of these best management practices, collectively termed low impact development, which can be used to manage stormwater volume and protect the water resources and natural heritage systems over the long term. Any new municipal strategies and policies for stormwater management through GSI and LID, such as a stormwater charge and credit, would most likely be integrated to all levels of environmental and municipal land use planning as illustrated in the diagram. The literature has provided a number of supporting high level planning policy, guidance and implementation manuals in place or under development which are supporting the management of rain where it falls through Low Impact Development and Green Stormwater Infrastructure. From this review there appears to be a disconnect between the high level policy framework for land use planning and infrastructure planning where the shovel hits the dirt. The gap is partially due how decisions are made for SWM on a capital or private development project requiring approvals.

Not listed above in the Policy Framework, is the role that Environmental Assessment Act, may have on the final implementation. It is listed here as an example of a legislative framework that is not connected to stormwater management, LID, or GI, but important nevertheless because a project engineer may be required to follow a Class Environmental Assessment for approval. A policy gap exists with the EA as it requires that the project only consider the Provincial Plans, PPS and supporting framework for SWM, but do not necessarily have to implement them.

The Interpretation Bulletin: Ontario Ministry of Environment and Climate Change Expectations Re: Stormwater Management acknowledges that the current approvals processes do not always support the installation of LID and GSI. It is hoped that new Provincial manual on LID for Environmental Compliance Approvals will outline the process and expectations for incorporating GSI, and establish provincial targets for stormwater volume reduction (Blakelock \& Maynes, 2016). 
Municipal SWM plans detail specific measures to be carried out for a specific development or redevelopment site and vary based on each municipality and site requirements. Infrastructure planning and budgetary systems are currently not supportive of the multi-stakeholder work (Figure 11) required to integrate SWM Master Planning (Credit Valley Conservation, 2015).

There are also

new municipal policies for

adopting green

stormwater infrastructure

with supporting policies as

part of their stormwater

management plan or wet

weather flow master plans

(Saxe, 2015). These

include minimum

standards, charges, and

incentives for achieving

higher performance

measures through LID and

GI, which are explored in

further detail in the next

\begin{tabular}{|c|c|c|}
\hline Department & $\begin{array}{l}\text { Role in Stormwater Management } \\
\text { Master Planning Process }\end{array}$ & Skills Required \\
\hline Engineering & $\begin{array}{l}\text { Engineering staff responsible for } \\
\text { the management of municipal } \\
\text { stormwater infrastructure need to } \\
\text { provide significant technical data } \\
\text { regarding design, assumption, } \\
\text { inspection, monitoring, operations, } \\
\text { maintenance and capacity of } \\
\text { infrastructure. }\end{array}$ & $\begin{array}{l}\text { Engineering staff have an } \\
\text { understanding of where existing } \\
\text { problem-areas are located, and } \\
\text { will ultimately be responsible for } \\
\text { ensuring now works are carried } \\
\text { out accordingly. }\end{array}$ \\
\hline Planning & $\begin{array}{l}\text { Planning staff are required for } \\
\text { integration with planning } \\
\text { documents such as environmental } \\
\text { management reports and municipal } \\
\text { planning policies, bylaws, official } \\
\text { plans, etc.. }\end{array}$ & $\begin{array}{l}\text { Planning staff can ensure } \\
\text { ESWM-MP follows overarching } \\
\text { municipal plans, and may need } \\
\text { to be involved with new by-laws } \\
\text { and policies as a result of the } \\
\text { ESWM-MP. }\end{array}$ \\
\hline Capital Works & $\begin{array}{l}\text { Capital works input is required to } \\
\text { determine budget allocation of } \\
\text { stormwater management projects } \\
\text { and determine where costs savings } \\
\text { can be realized. }\end{array}$ & $\begin{array}{l}\text { Capital works staff will } \\
\text { contribute to implementation } \\
\text { plan for ESWM-MP. }\end{array}$ \\
\hline Roads & $\begin{array}{l}\text { Roads department input is required } \\
\text { to evaluate potential for } \\
\text { conveyance level stormwater } \\
\text { implementation and integration into } \\
\text { other capital projects. }\end{array}$ & $\begin{array}{l}\text { Inclusion of roads staff to } \\
\text { streamline construction projects } \\
\text { and to ensure there is an } \\
\text { understanding of maintenance } \\
\text { requirements for stormwater } \\
\text { conveyance works }\end{array}$ \\
\hline Parks & $\begin{array}{l}\text { Parks department input is required } \\
\text { to evaluate the potential for } \\
\text { integration of stormwater with } \\
\text { parks and recreation programs. }\end{array}$ & $\begin{array}{l}\text { Inclusion of parks staff to } \\
\text { ensure there is an } \\
\text { understanding of maintenance } \\
\text { requirements for stormwater } \\
\text { works in parks. }\end{array}$ \\
\hline Geomatics & $\begin{array}{l}\text { GIS staff will need to provide and } \\
\text { coordinate geospatial data with } \\
\text { project team. }\end{array}$ & $\begin{array}{l}\text { Required for completion of } \\
\text { ESWM-MP and on ongoing } \\
\text { basis as works completed. }\end{array}$ \\
\hline
\end{tabular}

Figure 11: Municipal Departments Involved in SWM Master Planning (Source: CVC)

sub-chapter of the report. The literature, acknowledges that issues with implementation of GSI are much more complex than the regulatory, approvals and financing process. Chapters 4 will explore the additional barriers, such as knowledge and skills gaps that are associated with the adoption of new technologies and supportive services. 
CHAPTER 3: LITERATURE REVIEW

STORMWATER MANAGEMENT: ONTARIO MUNICIPAL POLICIES FOR GREEN INFRASTRUCTURE

\subsection{Financing Options on GI Programs for SWM}

In order to provide recommendations or options for a GSI policy that requires a finance strategy, the literature review examined the funding rationale and financing options available to Ontario municipalities along with their potential issues. The literature revealed grants for start-up, two traditional financing mechanisms including wastewater surcharge and property tax for operations (Tassonyi, 2002), external funding mechanisms, and new municipal financing models adopted for GSI programs. This further helped to understand the responses and choices for best practices from the interviewees. For infrastructure requiring inter-departmental cooperation, there may be limited options for the revenue components of a finance model.

\section{The Rationale for Exploring Financing Models of a GSI Program}

The economic functions with a local government are to create efficiency in allocating resource and pricing of the services (costs, fees, and revenue); provide equity in the distribution or redistribution of resources and services for the well-being of the people; and to maintain economic growth and stabilization with accountability and evaluation of the service/performance (Amborski, Fiscal Reform: Municipal Finance and Local Governance, 2015), which are in the public interest. Any program that results in infrastructure installed in a public ROW and/or is maintained and managed by municipal staff in some capacity, or outsourced by municipal is considered a municipal asset and thus requires a budget and financial model to operate.

Funding for stormwater or greywater servicing in Ontario is commonly categorized as wastewater, due to conventional collection and treatment systems (Ontario Municipal Benchmarking Initiative, 2014). Municipalities would require a new or additional funding mechanism to plan, design, install and operate engineered GSI in the public realm, as well as subsidize and monitor installations by the private sector. In most cases there is a funding gap and lack of capacity to plan, design, install, and operate and maintain GSI programs. 
CHAPTER 3: LITERATURE REVIEW

STORMWATER MANAGEMENT: ONTARIO MUNICIPAL POLICIES FOR GREEN INFRASTRUCTURE

The Dilemma with Financing GSI Programs

The literature states that LIDs have demonstrated a net economic benefit, in addition to addressing other environmental, economic, and social issues. However, municipalities must address the challenge of new interdepartmental business practices requiring financial and management agreements and protocols. GSI programs raise the dilemma of who benefits, and who pays for the planning, design, installation, operations and management. The options for expenditure budgeting associated with the capital (start-up costs) and operations (maintenance) involved with Green Stormwater Infrastructure program would require an inter-departmental municipal initiative in most cities, such as Toronto (Boudreau, S.; Stott, S.; \& Cheung, P.; personal communication, May 2015). The argument can be made that the responsibility should continue with water/wastewater services as GSI improves the cost of increasing the size and capacity of grey infrastructure required to accommodate the higher frequency of intense storms and flooding. However, the scenario is complex, as responsibility of installation and maintenance of some GSI element may be shared with other departments (e.g., public works for construction, sanitary for cleaning, and parks and forestry for trees). These other departments may also require higher operational budgets to accommodate the additional capacity requirements.

Local governments have various financial tools available which they can use for budgeting of municipal programs, services and for the capital costs of infrastructure and services in new developments through instruments such as Development Charges (DC), property taxes, water surcharge, and user fees. The way in which a municipality has structured its budget and revenue model has implications to decisions on where and how development will occur, including intensification. Municipal governments can affect urban form not only with planning tools, such as planning and zoning by-laws, but also with municipal financial tools. As an example, lowering a DC rate to attract development does not reflect the full cost for infrastructure and services required for this type of development (Slack E. , 2006) and the additional strain it has on existing infrastructure. 
CHAPTER 3: LITERATURE REVIEW

STORMWATER MANAGEMENT: ONTARIO MUNICIPAL POLICIES FOR GREEN INFRASTRUCTURE

\section{Revenue Source: Federal Grants}

Federal funding to Canadian municipalities is available through the Federation of Canadian Municipalities' (FCM) Green Municipal Fund (GMF) for stormwater management projects which aims to mitigate the impact of first flush runoff. The project must demonstrate the potential to eliminate all site runoff for the 90th percentile of all 24-hour rainfall events, by volume (i.e., rain events over 12 months where rainfall volume is lower than or equal to 90 per cent of the amount seen in all 24-hour rainfalls). For example, if the 90th percentile rainfall is $15 \mathrm{~mm}$, this means that roughly 90 per cent of the time, the amount of rain received during a 24 -hour period is $15 \mathrm{~mm}$ or less. Eligible GSI projects through FCMGMF include: rainwater collection and reuse; green roofs; rain gardens for bio-retention; infiltration initiatives such as stormwater planters, infiltration trenches and permeable pavements (Federation of Canadian Municipalities, 2015). It is unclear if this funding source will be a temporary measure or a permanent response to retrofitting and updating existing municipal infrastructure.

\section{Revenue Source: Provincial Tools}

Municipalities in Ontario can provide financial incentives, in order to achieve planning objectives that are for the broader public good. Lower-tier and single-tier municipalities can plan for community improvement through grant and/or loan programs that support a municipality's community-building goals, which include LID and improving streetscapes. Upper-tier municipalities under the Planning Act can adopt Community Improvement Plans (CIP) relating to infrastructure and transit corridors (O. Reg. 550/06). Inter-governmental co-ordination between lower-tier and upper-tier is possible for grants or loans. CIP programs can be tailored to support municipal redevelopment and revitalization goals such as rural and urban green building practices, which would include GSI in the ROW and through privatesector development or retrofitting of existing buildings for energy efficiency. A CIP does not require provincial approval, however, municipalities must consult with the Province in accordance with the Planning Act and the PPS (Ministry of Municipal Affairs and Housing, 2008). 
CHAPTER 3: LITERATURE REVIEW

STORMWATER MANAGEMENT: ONTARIO MUNICIPAL POLICIES FOR GREEN INFRASTRUCTURE

Finance Model: Water \& Wastewater Surcharge

Funding for wastewater services in Ontario has been traditionally accomplished through

municipal water rates, which are usually included as a sewer surcharge based on water usage to recover the costs of wastewater collection and treatment (Ontario Municipal Benchmarking Initiative, 2014). This is a regressive charge as it does not account for stormwater, or pay for the additional GSI services required. It is essentially an unfair system for high users of water, which may ultimately not be contributing to wastewater or stormwater, for instance food and beverage processing, or high-rise residential occupants, and laundries. In those instance the water user is paying a higher fee, but has a small stormwater footprint in relation to others water uses who would pay less. It further does not encourage any developer, land owner, or property manager to install GSI retrofits.

\section{Finance Model: Property Tax}

This is another traditional/conventional approach of charging a rate for usage based on the property type and assessed land value. This is not only a regressive charge as it does not pay for additional GSI services, but it also does not reflect the stormwater contributions based on property type and amount of impervious cover for those who are actually contributing to stormwater. It unfairly charges a higher rate to land owners whose property value is strong, and at the same token have a lower tax for a property owner in that may have a large impervious area but lower property tax.

\section{Finance Model: Development Charges}

Development Charges (DC) are intended as a tool to have growth pay for the growth-related capital costs stemming from development can be described as a type of Direct Land Value Capture tool. DCs are levied for officially mandated municipal programs, and the funds collected have to be used to pay for the infrastructure made necessary by the development. In Ontario, wastewater services and stormwater drainage and control services are eligible services (Slack E. , 2006). The maximum collectable fees are equivalent to 100 per cent of the growth-related capital costs. Direct Land Value 
CHAPTER 3: LITERATURE REVIEW

STORMWATER MANAGEMENT: ONTARIO MUNICIPAL POLICIES FOR GREEN INFRASTRUCTURE

Capture tools are typified as stand alone policy instruments implemented under the normative rationale that landowners have an obligation to contribute a portion of community generated wealth into public coffers (Amborski, Land Value Capture - Lecture for Finance and Local Governance [MPL-8103], 2015).

\section{Dilemma of the Development Charge}

A DC downloads the risk of infrastructure capital to the private sector, and can be used by local government instead of raising property taxes to the entire population, which would not be fair to all users of the wastewater services (Amborski, Alternatives to Development Charges for Growth Related Capital Costs, 2011). The DC is ultimately passed on to the end consumer, when incorporated into the purchase price of a property (Bird \& Slack, 1991). Although DCs are traditionally considered progressive in relation to property taxes, in the context of stormwater fee, it is still a regressive fee, as payee on a new development is not the same as the responsible party for stormwater/wastewater service.

On the other hand, by imposing the DC, municipalities are able to provide incentives through a DC discount to private developers to advance certain interests (Slack, 1994). In Toronto, a rebate of $20 \%$ of the DC is a valued incentive to the private developer if they meet higher stringent, voluntary Tier 2 Performance of the Toronto Green Standard (City of Toronto, 2013). This financial tool can also be used by the municipality to borrow from the DC reserves to finance eligible growth-related capital costs as defined in the legislation (Mascarin, 2014), but does not ultimately pay for the long-term operations and maintenance required to ensure an effective and sustainable system.

\section{New Finance Model: Fee for Service in Ontario Municipalities}

In Ontario, the Cities of Waterloo and Kitchener established stormwater charge programs in 2011 and credit for impervious area reduction in 2013. The Cities of London (2015) and Mississauga introduced a stormwater charge program in January of 2016 (Saxe, 2015). Toronto is currently exploring a stormwater charge concept following council direction. This model is considered progressive, as it utilizes a charge for those who create SWM problems (i.e., large impervious surfaces), such as flat (non- 
CHAPTER 3: LITERATURE REVIEW

STORMWATER MANAGEMENT: ONTARIO MUNICIPAL POLICIES FOR GREEN INFRASTRUCTURE

green) roofs and parking lots, and provides a credit for to manage rain where it falls through GSI. Not

only are stormwater fees a fairer way of charging for SWM, but they also create an important financial incentive for property owners and tenants to reduce the impervious surfaces on their land. It further creates a sustainable revenue stream, with capital to finance GSI installations along the public ROW.

New Financial Model: Tiered Flat-Fee (In Cities of Kitchener and Waterloo, and studied by Vaughan)

A series of rate tiers for stormwater charges were established in the municipalities of Kitchener and Waterloo in 2013 through a new Stormwater Utility (Table 3). The rate is calculated based on property type, size, and amount of impervious area to account for the degrees of runoff generated. Within same property types, a larger size area will pay more due to it larger impermeable surface area. An owner can reduce the rate by demonstrating infiltration through LID/GSI, with stormwater credits can offset up to $45 \%$ of the stormwater portion of each property's utility bill (City of Kitchener, 2015). In Kitchener, the SW charge creates a dedicated fund for SWM (\$13M per year). The rate is progressive and increases annually, with a 10\% increase in 2015 (Personal Communication, 2016).

Table 3: Kitchener Stormwater Charge Classification (2015 rate)

(Source: City of Kitchener)

\begin{tabular}{|l|l|l|}
\hline Stormwater Classification Code & $\begin{array}{l}\text { Basis for Charge } \\
\text { Residential Single Detached: Small }\end{array}$ & $\begin{array}{l}\text { Detached homes with building footprint* } \\
\text { size of } 105 \mathrm{~m}^{2} \text { or less }\end{array}$ \\
\hline $\begin{array}{l}\text { Residential Single Detached } \\
\text { Medium }\end{array}$ & $\begin{array}{l}\text { Detached homes with building footprint* } \\
\text { between } 106-236 \mathrm{~m}^{2}\end{array}$ & $\$ 6.28$ \\
$\begin{array}{l}\text { Residential Single Detached } \\
\text { Large }\end{array}$ & $\begin{array}{l}\text { Detached homes with building footprint* } \\
\text { size of } 237 \mathrm{~m}^{2} \text { or more }\end{array}$ & $\$ 10.48$ \\
\hline $\begin{array}{l}\text { Residential } \\
\text { Townhouse/Semi-Detached }\end{array}$ & Per dwelling unit & $\$ 7.48$ \\
\hline Residential Condominium & Per dwelling unit & $\$ 4.18$ \\
\hline Multi-Residential duplex & Per building & $\$ 8.39$ \\
\hline Multi-Residential triplex & Per building & $\$ 12.59$ \\
\hline Multi-Residential four-plex & Per building & $\$ 16.76$ \\
\hline Multi-Residential five-plex & Per building & $\$ 20.96$ \\
\hline Multi-Residential (>5 units) & Per property (per\# of dwelling units) & $\$ 2.10$ \\
\hline Non-Residential Smallest & $26-1,051 \mathrm{~m}^{2}$ of impervious area & $\$ 20.05$ \\
\hline Non-Residential Small & $1,052-1,640 \mathrm{~m}^{2}$ of impervious area & $\$ 53.60$ \\
\hline Non-Residential Medium-Low & $1,641-7,676 \mathrm{~m}^{2}$ of impervious area & $\$ 140.44$ \\
\hline Non-Residential Medium-High & $7,677-16,324 \mathrm{~m}^{2}$ of impervious area & $\$ 409.96$ \\
\hline Non-Residential Large & $16,325-39,034 \mathrm{~m}^{2}$ of impervious area & $\$ 993.62$ \\
\hline Non-Residential Largest & $39,035 \mathrm{~m}^{2}$ or greater of impervious area & $\$ 2,133.07$ \\
\hline
\end{tabular}


CHAPTER 3: LITERATURE REVIEW

STORMWATER MANAGEMENT: ONTARIO MUNICIPAL POLICIES FOR GREEN INFRASTRUCTURE

New Finance Model: Simple Flat Rate (In City of Mississauga)

Mississauga implemented a full plan for a stormwater charge on January 1, 2016, based on a flat rate system for each type of property and their "roof-print area". The program has built an interdepartmental team, with the charge managed by Transportation and Works. Single-family residential homes will be charged one of five flat rates; while Multi-family residential and non-residential properties will be charged according to the number of "stormwater billing units" on each property, where each billing unit (267 m2) is equal to the average impervious area found on a single detached residential property in Mississauga (City of Mississauga, 2015). A Stormwater Credit Program for multi-residential and/or non-residential properties has been developed with four categories and credit amounts (City of Mississauga, 2015). The credit is capped at $50 \%$, determined as the maximum value that private on-site SWM practices could benefit. A subsidy will be introduced to help offset the cost of stormwater charges assessed to eligible places of religious worship and veterans' organization properties.

New Finance Model: Modified Simple Flat Rate (Studied by the City of Toronto)

The City of Toronto is exploring a concept for a simple flat rate stormwater charge. A staff report to recommended that funding for Toronto Water's growing Capital Program related to stormwater management move from a water rate funded program to a dedicated stormwater charge funded program. The stormwater charge explored is based on the following criteria (Toronto Water, 2015):

- A flat rate for residential properties (including detached and semidetached homes, duplexes, triplexes, townhouses and row houses);

- A flat rate for condominiums, multi-family residential, and industrial, commercial and institutional properties;

- For a property one hectare (1 ha) or greater, a specific charge based on the amount of runoff they contribute to the City's stormwater management system;

- An incentive program for properties one hectare (1 ha) or greater that manage a portion or all their stormwater runoff onsite. 


\subsection{Precedent from U.S. Cities with Green Infrastructure Programs}

Stormwater runoff through GI policies is at an adoption stage considered as an early majority with over 1,400 U.S. cities adopting stormwater charges (Figure 11) (Berthiaume, Quiroz, \& Ivey, 2015) and a handful of leaders with Green Street (Figure 12) manuals and policies (Goo, 2016).

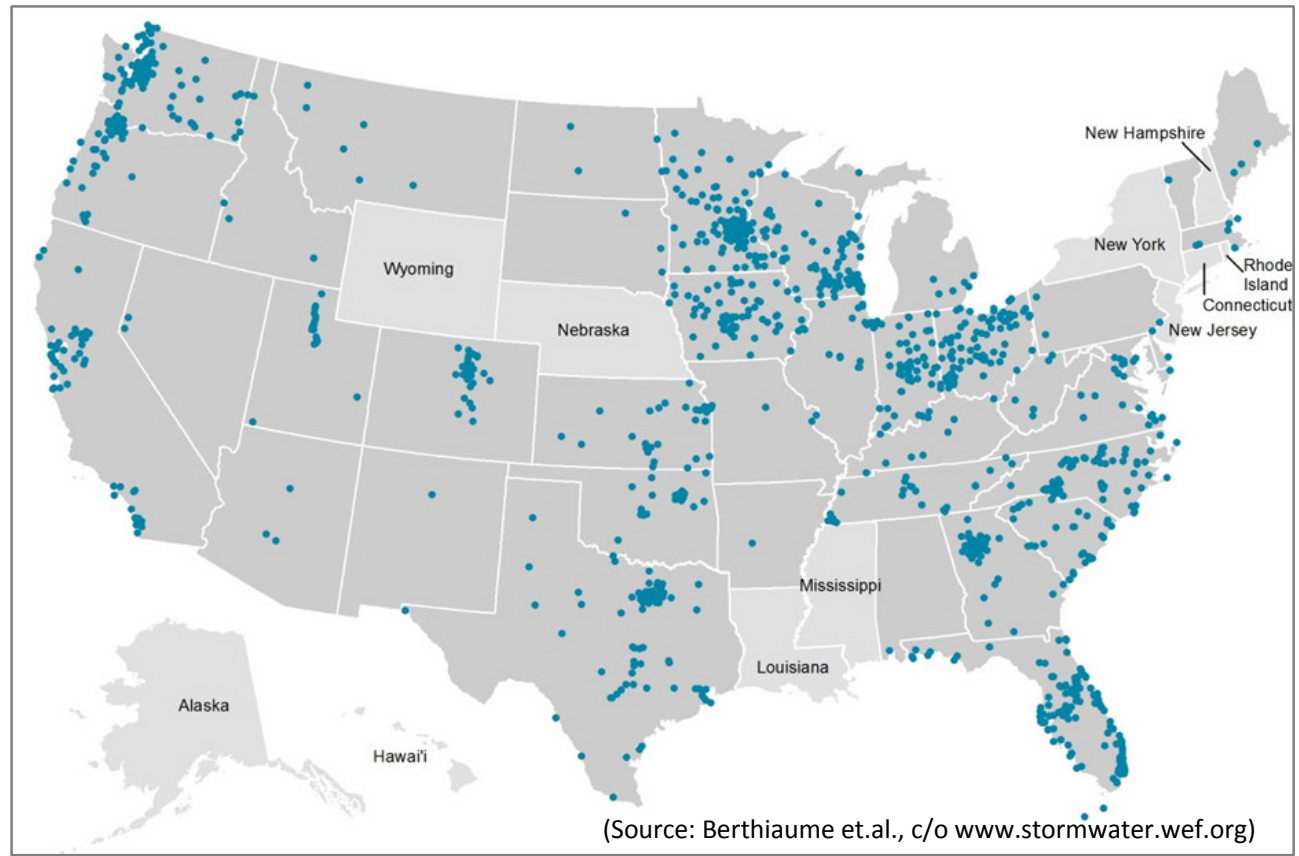

Figure 12: U.S. cities with a Stormwater Charge (as of 2013)

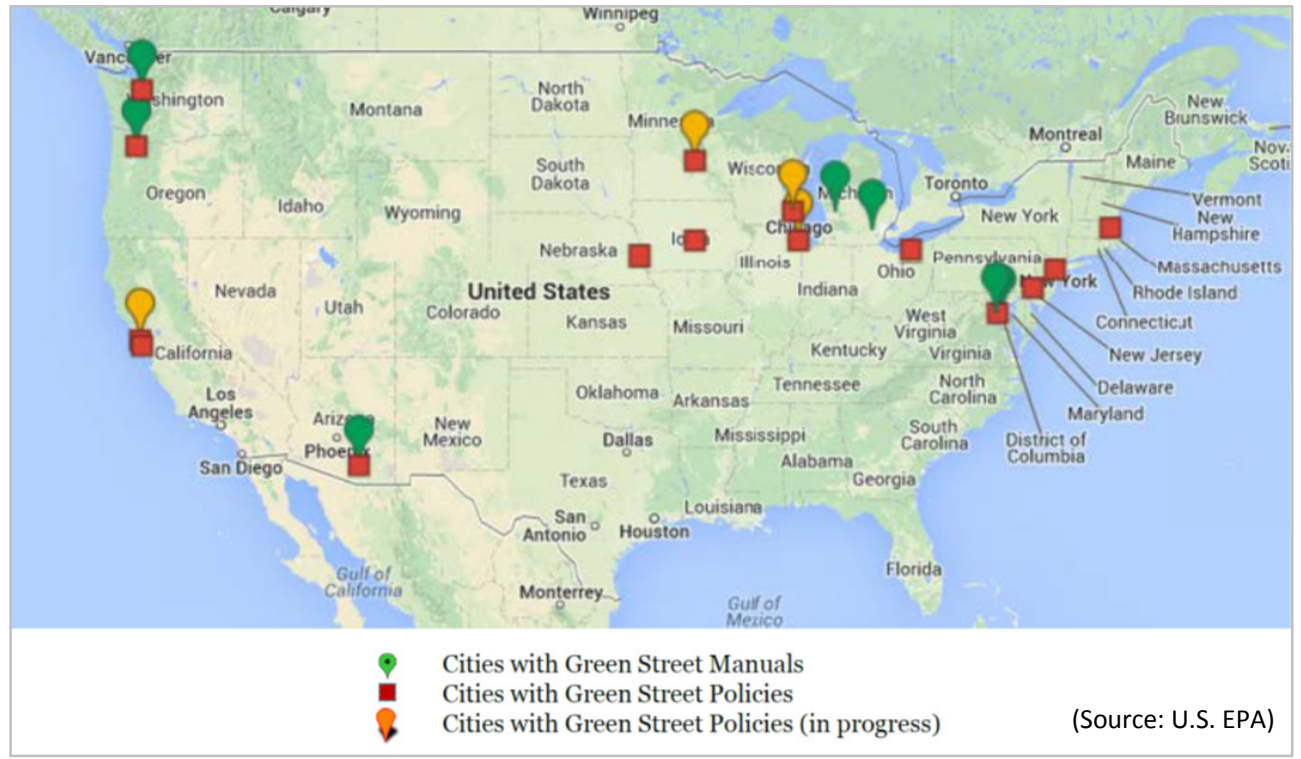

Figure 13: U.S. Cities with Green Street Policies 


\section{STATE OF PRACTICE FOR GSI POLICIES \& PROGRAMS}

Significant public interest arising from flooding and the inability of grey water infrastructure to address associated issues is lending support for GSI installations such as conveyance controls, water retention, and landscaping treatments. These sustainable approaches take into account environmental ${ }^{10}$, economic, and social factors, and attempts to incorporate GSI into land use planning and asset management. Green Streets support active transportation and complete streets, enhancing the quality of society ${ }^{11}$ through design interventions, amenities and aesthetics in both the public realm and on private property installations (Blakelock \& Maynes, 2016). The required SWM depends on attributing factors such as precipitation, gradient, drainage patterns, impermeability, collection \& retention systems and other conveyance controls (Boudreau, S., personal communication, 2016).

Urban municipalities across Southern Ontario are exploring GSI to support conventional grey infrastructure. Incorporating green infrastructure at the earliest stages of development is critical to tackling the issues and generally less expensive than larger-scale conventional stormwater controls (Porter-Bopp, Brandes, \& Sandborn, 2011). Low Impact Development (LID) strategies includes both planning techniques such as alternative designs (Figure 14)

for land use development (e.g., building and landscape layout, impervious areas) and GSI engineering techniques.

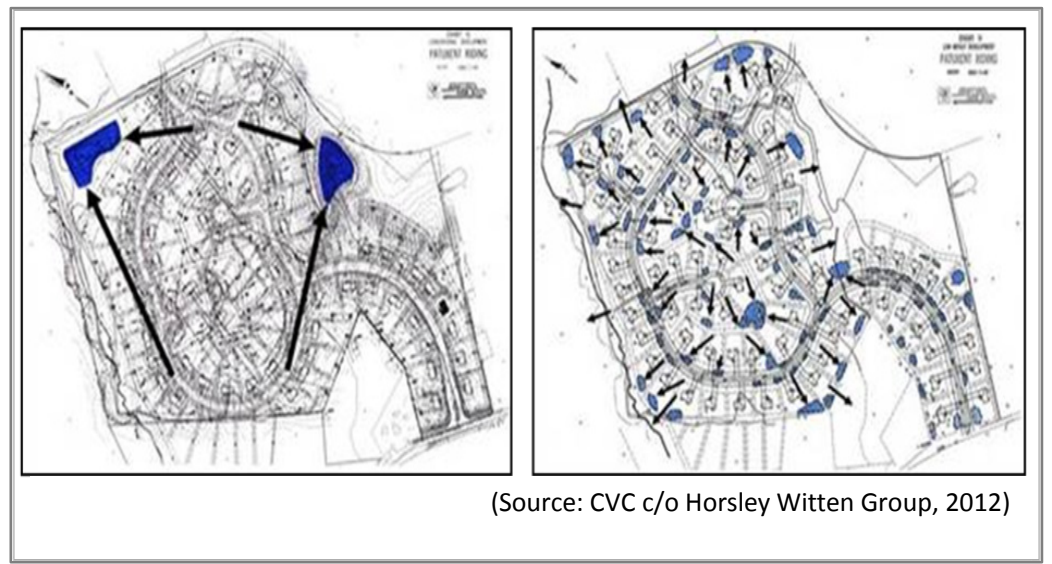

Figure 14: Conventional end-of-pipe vs LID Strategy for sub-division

${ }^{10}$ Green Stormwater Infrastructure reduces impact of flooding, prevents contamination of natural waters from urban pollutants (Toronto and Region Conservation Authority, 2012), and replaces dark, paved surfaces thus reducing the urban heat island effect (Porter-Bopp, Brandes, \& Sandborn, 2011).

${ }^{11}$ Co-benefits of Green Streets to SWM include vegetation for improved air quality, shade and aesthetics, while design interventions such as bump outs that narrow roadways at pedestrian crossings will slow vehicle traffic flow to provide for a more pleasant pedestrian and cyclist environments (Blakelock \& Maynes, 2016). 
The literature indicates GSIs are effective in SWM and viable in costs, but there are stages to adoption before it is "business as usual". The market adoption lifecycle illustrates the relationship of acceptance and risk for all new solutions faced over time. The risk in adoption is about more than just the technology (i.e. assess if it works and how it works best), but encompasses a complex approach that includes aspects of economics, organizational structure and management, regulatory, and society (Bloom Centre for Sustainability, 2012).

The findings from the literature review and analysis from the interviews with municipal representatives and private developers were used to identify: the potential barriers to adoption and drivers for adoption such as policies, tools and resources, which are further illustrate through the interview findings for each

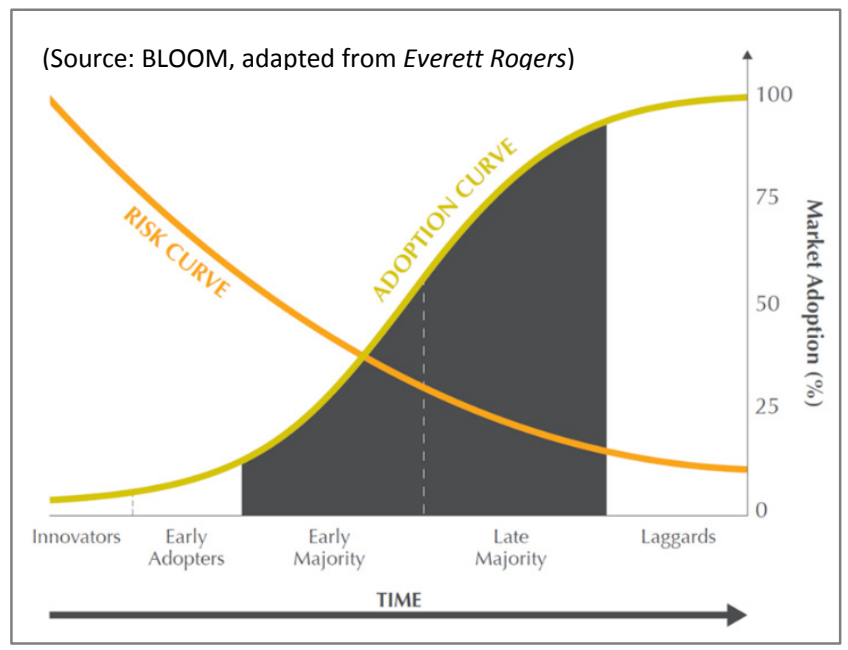

Figure 15: Market Adoption Lifecycle

of the five municipalities. The following operational steps (best practices) for adoption of Green Streets were adapted from the Roads and Runoff: Workshop Discussion Paper (Blakelock \& Maynes, 2016):

a. Establish team early with inter-departmental representatives and diverse skillsets.

b. Promote benefits to all stakeholders through various public media and outreach vehicles.

c. Implement Strategy through a systematic approach for GSI to be business-as-usual.

d. Integrate Capital Projects with GSI design and LID. Examples: road or sidewalk construction or resurfacing; neighbourhood beautification; and capital projects.

e. Standardize and streamline approvals in line with Provincial policies and regulations.

f. Complement other policy goals (e.g. traffic calming measures, tree canopy, climate change, healthy living, active transportation and complete streets).

g. Share resources with other early adopters to grown LID/GI market, which may reduce costs through economies of scale.

h. Train and provide guidance to all key staff (planners, engineers, design and landscaping, construction, approvals, standards, and maintenance). 


\subsection{Barriers to Adoption}

A "Workshop Discussion Paper" to the Roads and Runoff Workshop: Implementing Green Streets

in the Greater Golden Horseshoe, identified 12 key barriers to adoption of Green Streets (Blakelock \&

Maynes, 2016). The barriers identified were adapted and sorted based upon two overarching categories

related to (a) Policy, Coordination, \& Communication; and (b) Capacity, Design, \& Financing (Table 5).

Table 4: Barriers to Adoption of Green Stormwater Infrastructure

\begin{tabular}{|c|c|}
\hline Related to Policy, Coordination, \& Communication & Related to Capacity, Design, \& Financing \\
\hline $\begin{array}{l}\text { 1) Decision-making, Approval \& Review } \\
\text { - Strategic planning \& direction (high level) } \\
\text { - } \text { Design criteria, standards and specification for } \\
\text { - GSI types and SWM } \\
\text { - Standardized review processes }\end{array}$ & $\begin{array}{l}\text { i) Costs of GSI (widespread adoption) } \\
\text { - } \quad \text { Cheaper life-cost, but higher up-front } \\
\text { - Increased planning \& design } \\
\text { - } \quad \text { Materials may not be available locally } \\
\text { - Special maintenance equipment }\end{array}$ \\
\hline $\begin{array}{l}\text { 2) } \text { Communication \& Coordination } \\
\text { - } \quad \text { Cross-departmental approach required } \\
\text { - Often separate budgets \& priorities } \\
\text { - Scheduling of staff \& resources } \\
\text { - } \quad \text { Understanding of design \& maintenance }\end{array}$ & $\begin{array}{l}\text { ii) Capacity (staff, consultants, \& contractors) } \\
\text { - Planning stage } \\
\text { - Design phase } \\
\text { - Construction } \\
\text { - Maintenance \& Operations } \\
\end{array}$ \\
\hline $\begin{array}{l}\text { 3) Local Regulations \& Standards (competing) } \\
\text { - Minimum ROW and parking requirements } \\
\text { - Grey infrastructure requirements that do not } \\
\text { allow for reduced sizing with inclusion of Green } \\
\text { Infrastructure }\end{array}$ & $\begin{array}{l}\text { iii) Design Challenges } \\
\text { - Limited space for installation or maintenance } \\
\text { - Tight soils or low ground water table } \\
\text { - Other use in Right-of-Way (infrastructure) }\end{array}$ \\
\hline $\begin{array}{l}\text { 4) Awareness \& Information } \\
\text { - Key decision-makers, managers, \& public } \\
\text { - Integrating GSI into current projects } \\
\text { - } \text { Benefits of GSI to all stakeholders } \\
\end{array}$ & $\begin{array}{ll}\text { iv) } & \text { Performance of GSI } \\
\text { - } & \text { Particular soil conditions (tight soils) } \\
\text { - } & \text { Large scale properties (amount of runoff) } \\
\text { - } & \text { Cold climate or intense weather events } \\
\end{array}$ \\
\hline $\begin{array}{l}\text { 5) Responsibility of lower vs. upper tier Gov. } \\
\text { - Coordination between Regional and Local Gov. } \\
\text { for SWM on some roads and land }\end{array}$ & \begin{tabular}{|l} 
v) Maintenance (requirements \& resources) \\
- Increase requirements for vegetation and \\
cleaning to retain infiltration capacity
\end{tabular} \\
\hline $\begin{array}{l}\text { 6) Champions, Leaders, \& Advocates } \\
\text { - Staff level (expert, coordinator, or liaison) } \\
\text { - Decision-maker (council or board) }\end{array}$ & 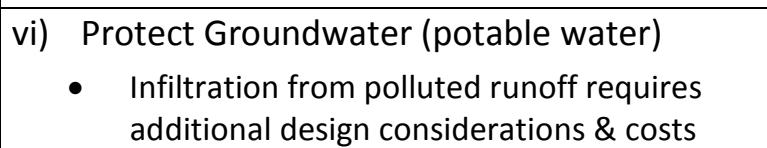 \\
\hline
\end{tabular}

Note: these barriers may not apply to all GI, only certain approaches or under specific site conditions.

Although each barrier should probably be viewed in the context of a specific municipality and

GIS policy, an attempt was made to place a general hierarchal order from the lens of any early-stage

municipality. The top barriers will likely require more effort to overcome due to either real and/or

perceived issues and complexity of adoption as a municipal wide policy for GSI. 


\subsection{Drivers for Adoption}

The literature review revealed that the state of practice is rich with up-to-date resources and

knowledge sharing that supports a municipal team with implementation and barriers identified such as

the technical challenges with LID practices. Key resources have been summarized in the table below.

Table 5: Resources to support adoption of GSI

\begin{tabular}{|c|c|c|}
\hline GSI Resource & Description & $\begin{array}{l}\text { Provider \& } \\
\text { Reference }\end{array}$ \\
\hline $\begin{array}{l}\text { Low Impact Development } \\
\text { Stormwater Management } \\
\text { Planning and Design Guide }\end{array}$ & $\begin{array}{l}\text { Implementation strategy for LID practices, \& fact } \\
\text { sheets on LID technology designs and findings } \\
\text { form demonstrations } \\
\text { (www.sustainabletechnologies.ca) }\end{array}$ & $\begin{array}{l}\text { Sustainable } \\
\text { Technologies (Credit } \\
\text { Valley Conservation; } \\
\text { Toronto and Region } \\
\text { Conservation } \\
\text { Authority, 2011) } \\
\end{array}$ \\
\hline $\begin{array}{l}\text { The Stormwater Management } \\
\text { Criteria }\end{array}$ & $\begin{array}{l}\text { Guidance in the planning and design of SWM } \\
\text { infrastructure. Outlines the processes \& } \\
\text { infrastructure to address flooding, water quality, } \\
\text { erosion, water balance, and natural heritage }\end{array}$ & $\begin{array}{l}\text { TRCA (Toronto and } \\
\text { Region Conservation } \\
\text { Authority, 2012) }\end{array}$ \\
\hline $\begin{array}{l}\text { Sustainable Technologies } \\
\text { Evaluation Program (STEP) }\end{array}$ & $\begin{array}{l}\text { Demonstration pilots and evaluations of LID } \\
\text { practices (www.thelivingcitycampus.com) }\end{array}$ & $\begin{array}{l}\text { Living Campus at the } \\
\text { Kortright Centre } \\
\text { (Toronto and Region } \\
\text { Conservation } \\
\text { Authority, 2012) }\end{array}$ \\
\hline $\begin{array}{l}\text { Grey to Green Retrofit Guides: } \\
\text { Road Retrofits; Enhanced } \\
\text { SWM Master Planning; } \\
\text { Business \& Multi-Residential } \\
\text { Retrofits; Public Land } \\
\text { Retrofits; \& Residential } \\
\text { Retrofits }\end{array}$ & $\begin{array}{l}\text { Step-by-step guidance on how to retrofit existing } \\
\text { properties to accommodate LID stormwater } \\
\text { management technologies, tailored to specific } \\
\text { uses and users }\end{array}$ & $\begin{array}{l}\text { CVC } \\
\text { (Credit Valley } \\
\text { Conservation, 2016) }\end{array}$ \\
\hline $\begin{array}{l}\text { LID Planning Framework (Lake } \\
\text { Simcoe Watershed) }\end{array}$ & $\begin{array}{l}\text { Used to determine suitable placement for LID } \\
\text { practices on a watershed scale, integrating } \\
\text { technical criteria, economical, and social aspects }\end{array}$ & $\begin{array}{l}\text { Thesis Dissertation } \\
\text { (Lawson, 2010) }\end{array}$ \\
\hline $\begin{array}{l}\text { Leadership in Energy and } \\
\text { Environmental Design } \\
(L E E D)^{13}\end{array}$ & $\begin{array}{l}\text { Green building certification that incorporates } \\
\text { SWM under a point system (refer to Glossary of } \\
\text { Terms for LEED categories) }\end{array}$ & $\begin{array}{l}\text { Canada Green Building } \\
\text { Council \& LEED Canada } \\
\text { (U.S. Green Building } \\
\text { Council, 2016) }\end{array}$ \\
\hline
\end{tabular}

${ }^{12}$ STEP is a multi-agency program, led by TRCA to provide the data and analytical tools necessary to support broader implementation of sustainable technologies and practices within a cold climate and Canadian context. Stormwater management and planning has been conducted and evaluated across the GTA, with resulting SWM criteria (TRCA, 2008-2013).

${ }^{13}$ LEED v4 (Updated July 1, 2015) includes applicable credits for Building Design and Construction, for Building Operations and Maintenance, Homes and Midrise, and for Neighbourhood Development. Refer to the Glossary of Terms for the intent of each LEED category listed (Canada Green Building Council; LEED Canada, 2016). 
In addition, the Water Technology Acceleration Project (Water Tap) promotes the development of Ontario's water and wastewater sectors, through a \$17 million Showcasing Water Innovation program (Figure 16) (Ontario's Great Lakes Strategy, 2012).

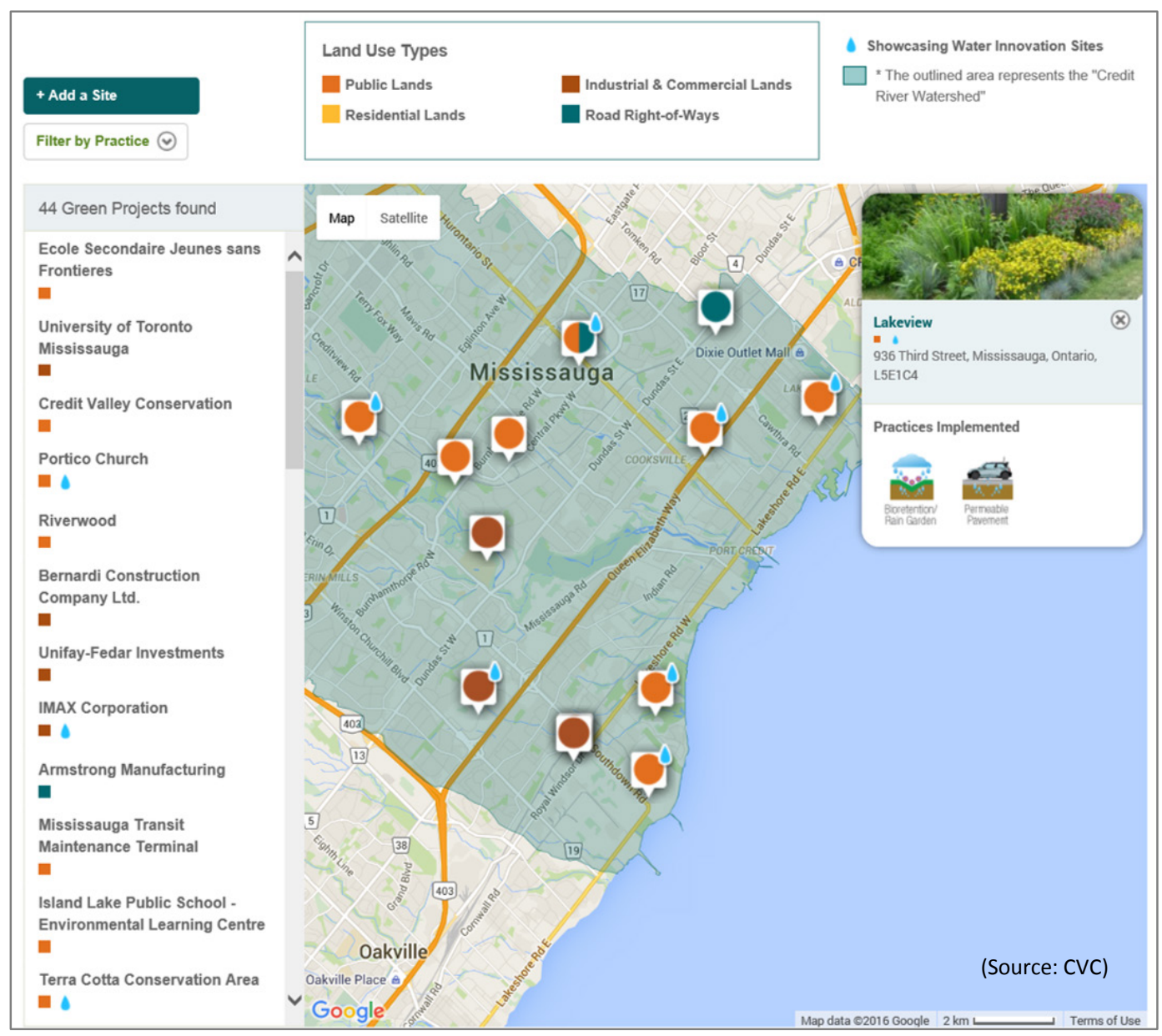

Figure 16: LID Map Showcasing Water Innovation

General strategies driving the adoption of GSI in U.S. cities were revealed through the literature research $($ Goo, 2016). These included: Wider spread adoption through positive performance from GSI demonstrations; Public accountability and transparency with a stormwater fee \& credit reporting; Economic development by transforming streets and beautifying the community; Increased competition amongst developers, practitioners, and government; Reduced implementation and operational cost through widespread (majority) adoption; Improved physical, social and psychological health through healthier and safer communities with sharing the right-of-way and separating the pedestrian realm; and Public acceptance and pride through multi-function designs that creates local places. 
CHAPTER 4: STATE OF PRACTICE FOR GSI POLICIES \& PROGRAMS

STORMWATER MANAGEMENT: ONTARIO MUNICIPAL POLICIES FOR GREEN INFRASTRUCTURE

A Life-Cycle Costs Comparison for LID Practices uses a parametric approach to incorporate

capital costs for design parameters, operations and maintenance cost (Water Environmental Research

Foundation). A generalization of life-cycle costs (Table 6) based on similar LID facility sizes is provided as

a comparison between common LID technologies (City of Edmonton, 2011).

Table 6: Life Cycle Cost for Low Impact Development Installations

\begin{tabular}{|c|c|c|c|c|}
\hline \multirow{3}{*}{ Feature } & \multicolumn{4}{|c|}{ Generalized Costs } \\
\hline & \multirow{2}{*}{ Construction } & \multirow{2}{*}{ Annual Maintenance } & \multicolumn{2}{|r|}{ Replacement } \\
\hline & & & Life Cycle ${ }^{1}$ & Cost \\
\hline $\begin{array}{l}\text { Rainwater Harvesting } \\
\text { System }\end{array}$ & $\begin{array}{c}\$ 212-\$ 1000 / \mathrm{m}^{3} \text { of } \\
\text { storage }\end{array}$ & $\begin{array}{l}\text { Fall irrigation } \\
\text { maintenance: } \$ 25 / \mathrm{yr} \\
\text { residential; cistern } \\
\text { flush } / \text { pump: } \\
\$ 100-\$ 150 / \mathrm{yr}\end{array}$ & $\begin{array}{l}25-100+ \\
\text { years }\end{array}$ & Construction costs \\
\hline Green Roofs & $\begin{array}{l}\text { Extensive: } \\
\$ 230-\$ 550 / \mathrm{m}^{2} \\
\text { intensive: } \\
\$ 500-\$ 3000 / \mathrm{m}^{2}\end{array}$ & $\begin{array}{c}\text { \$3-\$44/m² during first } \\
2 \text { years (reduced } \\
\text { following } \\
\text { establishment of } \\
\text { plantings after } 2-5 \\
\text { years) }\end{array}$ & $\begin{array}{l}30-50 \\
\text { years }\end{array}$ & $\begin{array}{l}\text { Replacement of waterproof } \\
\text { membrane } \$ 6 / \mathrm{m}^{2} \text { plus } \\
\text { general labour to remove } \\
\text { and replace green roof. }\end{array}$ \\
\hline Box Planters & $\$ 30-\$ 350 / \mathrm{m}^{2}$ & $\$ 13-\$ 30 / \mathrm{m}^{3}$ & $\begin{array}{l}25-50 \\
\text { years }\end{array}$ & $\begin{array}{l}\text { Construction costs; } \\
\text { drainage area } \\
\text { characteristics may require } \\
\text { replacement of soils } \\
\left(\$ 10-\$ 15 / \mathrm{m}^{2}\right) \quad 2-10 \text { times } \\
\text { more often than the } \\
\text { drainage structure }\end{array}$ \\
\hline Bioretention & $\$ 30-\$ 250 / \mathrm{m}^{2}$ & $\$ 13-\$ 30 / \mathrm{m}^{3}$ & $>20$ years & $\begin{array}{l}\text { Major } \quad \text { rehabilitation: } \\
\$ 4-\$ 170 / \mathrm{m}^{2} \text { every } 15-20 \\
\text { years }\end{array}$ \\
\hline Permeable Pavement & $\$ 340-\$ 500 / \mathrm{m}^{2}$ & $\begin{array}{c}\$ 0.15-\$ 0.30 / \mathrm{m}^{2} \text { for } \\
\text { vacuum or deep clean }\end{array}$ & $>20$ years & Construction costs \\
\hline Biowales & $\$ 11-\$ 35 / \mathrm{m}^{2}$ & $\$ 0.20-\$ 1.00 / \mathrm{m}^{2}$ & $>20$ years & $\begin{array}{l}\text { Construction costs; } \\
\text { drainage area } \\
\text { characteristics may require } \\
\text { replacement of sod and } \\
\text { soil }\left(\$ 15-\$ 20 / \mathrm{m}^{2}\right) \text { up to } \\
2 \text { times more often than } \\
\text { the drainage structure }\end{array}$ \\
\hline Naturalized Drainage Ways & $\$ 25-\$ 250 / \mathrm{m}^{2}$ & $<\$ 1-\$ 18 / \mathrm{m}^{2}$ & $\begin{array}{c}>20-100+ \\
\text { years }\end{array}$ & $\begin{array}{l}\text { Full replacement not } \\
\text { expected when well } \\
\text { maintained }\end{array}$ \\
\hline \multicolumn{5}{|c|}{$\begin{array}{l}\text { 'Expected life for well designed and maintained facilities } \\
\text { (TRCA, 2009; Wayne County, 2001; CRDWS, 2008; Peck, 2003; SWRPC, 1991; Alberta supplier/installers; AMEC, } \\
\text { pers. comm. 2010; Progressive Engineering Ltd, pers. comm, 2010) }\end{array}$} \\
\hline
\end{tabular}


Both public land managers and private sector developers adhering to LID principles ${ }^{14}$, are faced with complexity of not only the policies and financing, but also the selection of GSI based on their application and attributes (Table 7) requiring an interdisciplinary team or a very competent individual (Blakelock \& Maynes, 2016), which is further complicated with issues on management and financing.

Table 7: GSI Source Control Options with Attributes and User Applications

\begin{tabular}{|c|c|c|c|c|c|c|c|}
\hline Options & $\begin{array}{l}\text { Description \& Benefits } \\
(P=\text { primary; } S=\text { secondary, } \\
X=\text { no benefit })\end{array}$ & $\begin{array}{l}\text { Water } \\
\text { Quality }\end{array}$ & $\begin{array}{l}\text { Flood } \\
\text { Control }\end{array}$ & $\begin{array}{l}\text { Water } \\
\text { Balance }\end{array}$ & $\begin{array}{l}\text { Water } \\
\text { Use }\end{array}$ & $\begin{array}{l}\text { Sewer } \\
\& \text { CSO }\end{array}$ & Users \\
\hline $\begin{array}{l}\text { Bioretention } \\
\text { (including } \\
\text { bump-outs) }\end{array}$ & $\begin{array}{l}\text { Consists of plantings, mulch, } \\
\text { soil media, and a gravel } \\
\text { storage area. Can be placed } \\
\text { in established green spaces } \\
\text { around parking lots or in } \\
\text { landscaped areas. }\end{array}$ & $P$ & $S$ & $P$ & $x$ & $S$ & $\begin{array}{l}\text { Business, } \\
\text { Multi-Res., } \\
\text { ROW, } \\
\text { public land }\end{array}$ \\
\hline $\begin{array}{l}\text { Bioswales \& } \\
\text { enhanced grass } \\
\text { swale }\end{array}$ & $\begin{array}{l}\text { Bioretention facilities } \\
\text { designed for heavy wet } \\
\text { weather flows to infiltrate \& } \\
\text { convey runoff. }\end{array}$ & $P$ & $S$ & $P$ & $x$ & $S$ & $\begin{array}{l}\text { Business, } \\
\text { Multi-Res., } \\
\text { ROW, } \\
\text { public land }\end{array}$ \\
\hline $\begin{array}{l}\text { Fusion } \\
\text { Landscaping }{ }^{\circledR}\end{array}$ & $\begin{array}{l}\text { Combines lush traditional } \\
\text { gardens with modern, eco- } \\
\text { friendly plants for runoff. }\end{array}$ & $\mathrm{S}$ & $S$ & $P$ & $x$ & $S$ & Res \\
\hline Green Roofs & $\begin{array}{l}\text { Layer of growing media atop } \\
\text { a conventional flat roof. The } \\
\text { vegetation planted is } \\
\text { selected based on climate } \\
\text { conditions, desired } \\
\text { aesthetics, \& maintenance } \\
\text { considerations. }\end{array}$ & $S$ & $S$ & $P$ & $x$ & $S$ & $\begin{array}{l}\text { Business, } \\
\text { Multi-Res. }\end{array}$ \\
\hline Micro-grading & $\begin{array}{l}\text { Optimize temporary runoff, } \\
\text { detention \& infiltration }\end{array}$ & $x$ & $S$ & $\mathrm{P}$ & $x$ & $S$ & $\begin{array}{l}\text { Business, } \\
\text { Multi-Res., } \\
\text { public land }\end{array}$ \\
\hline $\begin{array}{l}\text { No-mow Zones } \\
\& \\
\text { Naturalization }\end{array}$ & $\begin{array}{l}\text { Naturalized area, create } \\
\text { healthy soils to increase } \\
\text { infiltration \& support plants }\end{array}$ & & & & & & $\begin{array}{l}\text { Business, } \\
\text { Multi-Res., } \\
\text { public land }\end{array}$ \\
\hline $\begin{array}{l}\text { Perforated } \\
\text { Pipe System }\end{array}$ & $\begin{array}{l}\text { Linear infiltration practices } \\
\text { on gently sloping granular } \\
\text { stone beds lined with } \\
\text { geotextile fabric. }\end{array}$ & $S$ & $S$ & $P$ & $x$ & $S$ & $\begin{array}{l}\text { Business, } \\
\text { Multi-Res., } \\
\text { Res. }\end{array}$ \\
\hline $\begin{array}{l}\text { Permeable } \\
\text { Pavers }\end{array}$ & $\begin{array}{l}\text { Pervious concrete, porous } \\
\text { asphalt, \& permeable } \\
\text { interlocking bricks allowing } \\
\text { drainage \& infiltration }\end{array}$ & $P$ & $\mathrm{P}$ & $P$ & $x$ & $S$ & $\begin{array}{l}\text { Business, } \\
\text { Multi-Res, } \\
\text { Res, ROW }\end{array}$ \\
\hline
\end{tabular}

${ }^{14}$ Key LID principles include: Preserving natural features; small-scale, integrated SMW controls throughout the site; minimizing impervious areas; controlling stormwater at its source; prolonging stormwater runoff flow paths and times; and creating multi-functional landscapes (City of Edmonton, 2011). 


\begin{tabular}{|c|c|c|c|c|c|c|c|}
\hline Options & $\begin{array}{l}\text { Description \& Benefits } \\
(P=\text { primary; } S=\text { secondary, } \\
X=\text { no benefit })\end{array}$ & $\begin{array}{l}\text { Water } \\
\text { Quality }\end{array}$ & \begin{tabular}{|l|} 
Flood \\
Control
\end{tabular} & $\begin{array}{l}\text { Water } \\
\text { Balance }\end{array}$ & $\begin{array}{l}\text { Water } \\
\text { Use }\end{array}$ & $\begin{array}{l}\text { Sewer } \\
\& \text { CsO }\end{array}$ & Users \\
\hline $\begin{array}{l}\text { Phosphorus } \\
\text { Removal } \\
\text { Media }\end{array}$ & $\begin{array}{l}\text { Products used in infiltration } \\
\text { galleries where phosphorus } \\
\text { loading is a threat to } \\
\text { receiving waters. }\end{array}$ & $\mathrm{P}$ & $x$ & $x$ & $x$ & $x$ & $\begin{array}{l}\text { Business, } \\
\text { Multi-Res., } \\
\text { public land }\end{array}$ \\
\hline $\begin{array}{l}\text { Precast Tree } \\
\text { Planters }\end{array}$ & $\begin{array}{l}\text { Prefabricated enclosures } \\
\text { that contain trees or shrubs, } \\
\text { bioretention soil media, and } \\
\text { a perforated pipe } \\
\text { underdrain }\end{array}$ & $P$ & $x$ & $x$ & $x$ & $x$ & $\begin{array}{l}\text { Business, } \\
\text { Multi-Res., } \\
\text { public land }\end{array}$ \\
\hline $\begin{array}{l}\text { Proprietary } \\
\text { Stormwater } \\
\text { Treatment } \\
\text { Devices }\end{array}$ & $\begin{array}{l}\text { Broad range of technologies } \\
\text { to treat stormwater (e.g., } \\
\text { hydrodynamic separators, } \\
\text { precast tree, planters, wet } \\
\text { vaults, and media filters). }\end{array}$ & $\mathrm{P}$ & $x$ & $x$ & $x$ & $x$ & $\begin{array}{l}\text { Business, } \\
\text { Multi-Res., } \\
\text { public land }\end{array}$ \\
\hline Rain Garden & $\begin{array}{l}\text { Bioretention plantings, } \\
\text { mulch, soil media, and a } \\
\text { gravel storage area. Size and } \\
\text { aesthetics are adaptable. }\end{array}$ & $P$ & $\mathrm{~S}$ & $P$ & $x$ & $S$ & Res. \\
\hline $\begin{array}{l}\text { Rainwater } \\
\text { Harvesting }\end{array}$ & $\begin{array}{l}\text { Intercepting and store } \\
\text { rainwater for future use } \\
\text { (rooftop as a catchment) }\end{array}$ & $S$ & $\mathrm{~S}$ & $x$ & $P$ & $x$ & $\begin{array}{l}\text { Business, } \\
\text { Multi-Res., } \\
\text { public land }\end{array}$ \\
\hline $\begin{array}{l}\text { Soakaways \& } \\
\text { Infiltration } \\
\text { Chambers }\end{array}$ & $\begin{array}{l}\text { Stone-filled trenches or pits } \\
\text { to store \& infiltrate water. } \\
\text { Prefabricated modular } \\
\text { structures over a granular } \\
\text { base, provides structural } \\
\text { support for parking. }\end{array}$ & $S$ & $P$ & $P$ & $x$ & $S$ & $\begin{array}{l}\text { Business, } \\
\text { Multi-Res., } \\
\text { public land }\end{array}$ \\
\hline $\begin{array}{l}\text { Soil } \\
\text { Amendments }\end{array}$ & $\begin{array}{l}\text { Organic materials added to } \\
\text { provide nutrients for plants, } \\
\text { control soil pH, and allow } \\
\text { for greater interaction } \\
\text { between runoff and soils }\end{array}$ & $S$ & $x$ & $P$ & $x$ & $S$ & $\begin{array}{l}\text { Business, } \\
\text { Multi-Res., } \\
\text { public land }\end{array}$ \\
\hline $\begin{array}{l}\text { Soil Support } \\
\text { Systems }\end{array}$ & $\begin{array}{l}\text { Modular frames (or cells) } \\
\text { that provide structural } \\
\text { support against compaction }\end{array}$ & $P$ & $S$ & $P$ & $S$ & $S$ & $\begin{array}{l}\text { Business, } \\
\text { Multi-Res., } \\
\text { public land }\end{array}$ \\
\hline Tree Clusters & $\begin{array}{l}\text { Evapotranspiration \& } \\
\text { infiltration }\end{array}$ & $\mathrm{S}$ & $\mathrm{S}$ & $P$ & $x$ & $S$ & $\begin{array}{l}\text { Business, } \\
\text { Multi-Res. }\end{array}$ \\
\hline Xeriscaping & $\begin{array}{l}\text { Refers to landscaping that } \\
\text { reduces irrigation }\end{array}$ & $x$ & $x$ & $S$ & $P$ & $x$ & $\begin{array}{l}\text { Business, } \\
\text { Multi-Res. }\end{array}$ \\
\hline $\begin{array}{l}\text { Wet Pond \& } \\
\text { Wetland \& } \\
\text { Hybrids }\end{array}$ & $\begin{array}{l}\text { Most common end-of-pipe } \\
\text { SWM facility }\end{array}$ & $P$ & $P$ & $x$ & $x$ & $x$ & Public land \\
\hline Dry Pond & $\begin{array}{l}\text { Depression to temporarily } \\
\text { detain rain }\end{array}$ & $x$ & $P$ & $x$ & $x$ & $x$ & Public land \\
\hline $\begin{array}{l}\text { Sub-surface } \\
\text { storage }\end{array}$ & $\begin{array}{l}\text { Tanks, cisterns or superspies } \\
\text { that detain stormwater } \\
\text { and/or CSO }\end{array}$ & $\mathrm{S}$ & $P$ & $x$ & $x$ & $P$ & Public land \\
\hline
\end{tabular}


CHAPTER 4: STATE OF PRACTICE FOR GSI POLICIES \& PROGRAMS

STORMWATER MANAGEMENT: ONTARIO MUNICIPAL POLICIES FOR GREEN INFRASTRUCTURE

\subsection{Analysis of Interviews on Municipal GSI Policies \& Projects}

The state of practice for each of the five municipalities (Cities of Kitchener, Mississauga, Toronto, Vaughan, and Waterloo) was revealed through interviews and supporting background documentation which helped to understand the setting and context in which these cities are adopting and exploring new GSI policies, programs, and practices. The interview questions were structured to corresponded with the findings of the literature review. In turn, the responses revealed similar patterns from both the municipal and private sector that corresponded to the findings in the literature review.

The largest and most common driver to all of the cities interviewed, including the private developers was regulatory compliance and higher standards for environmental quality, which was illustrated earlier through an extensive literature review on Policy Framework. Emerging legislation and municipal strategies are shifting the public and private sectors from conventional approaches to SWM to the adoption of GSI. Interestingly, the one private land developer that did not indicate compliance as a driver, affirmed a goal to achieve higher standards for GSI and sustainability, so as to distinguish their firm from others. All the developers were keen on maintaining the reputation built as being green.

A second driver that was common to all but one of the cities was the need to address with aging infrastructure and the need to negate end-of-pipe treatments and conveyance controls for SWM. This corresponded to the age of the municipal infrastructure, as was revealed in the literature review, with most sewer and water mains been all but one, the City of Vaughan, which is explained through its rapid growth as new urban centre, transforming from a rural to an urban city. Another driver common to all the respondents and one that tied to all others, was the need to create a new funding mechanism that would support GSI. It became clear, that many of the drivers were connected, such as addressing flooding and demonstrating pilot projects for GSI (Table 8), which require a new funding mechanism for capital costs and operating budgets of GSI. 
Table 8: Municipal Drivers for Adoption or Piloting GSI for SWM (Interviewee Responses)

\begin{tabular}{|c|c|c|c|c|c|c|c|c|}
\hline $\begin{array}{l}\text { What were the main drivers } \\
\text { for adopting or piloting a } \\
\text { program that promotes, } \\
\text { requires and/or advocates } \\
\text { Green Stormwater } \\
\text { Infrastructure? }\end{array}$ & 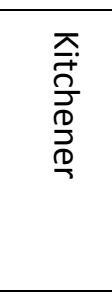 & 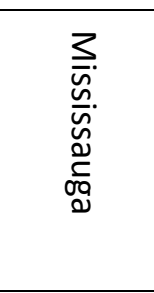 & $\begin{array}{l}\frac{-1}{0} \\
\frac{0}{0} \\
\text { ㅇ } \\
0\end{array}$ & 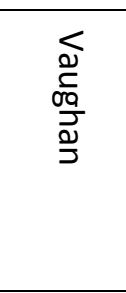 & $\begin{array}{l}\sum_{\substack{1 \\
+}}^{\frac{D}{D}} \\
\frac{1}{0} \\
0\end{array}$ & 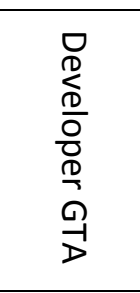 & 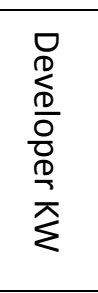 & 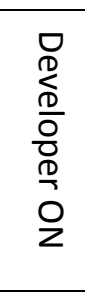 \\
\hline $\begin{array}{l}\text { Supporting Aging Grey } \\
\text { Infrastructure (service } \\
\text { disruptions, repair \& } \\
\text { replacement) }\end{array}$ & Yes & Yes & Yes & & Yes & - & - & - \\
\hline $\begin{array}{l}\text { Negating the need for new end- } \\
\text { of-pipe solutions or conveyance } \\
\text { controls }\end{array}$ & Yes & Yes & Yes & & Yes & - & - & - \\
\hline $\begin{array}{l}\text { Mitigating or responding to } \\
\text { localized flooding (basement, } \\
\text { street, riverine) }\end{array}$ & & Yes & Yes & Yes & & & & \\
\hline $\begin{array}{l}\text { Public space improvements (e.g., } \\
\text { green space, parks, right-of-way) } \\
\text { \& Visually attractive, marketable } \\
\text { amenity }\end{array}$ & & & Yes & Yes & & Yes & Yes & Yes \\
\hline $\begin{array}{l}\text { Restoration or protection of } \\
\text { waterways (discharge from } \\
\text { combined sewer overflows) }\end{array}$ & & & Yes & & & & & \\
\hline $\begin{array}{l}\text { Regulatory compliance, } \\
\text { environmental quality (WQ), } \\
\text { minimum standards }\end{array}$ & Yes & Yes & Yes & Yes & Yes & Yes & & Yes \\
\hline $\begin{array}{l}\text { Funding Incentives (federal, } \\
\text { provincial, and local/regional } \\
\text { government) }\end{array}$ & $\begin{array}{l}\text { MOE, } \\
\text { FCM, } \\
\text { CMHC }\end{array}$ & $\begin{array}{l}\text { TD Street } \\
\text { trees }\end{array}$ & & & & Local & Yes & \\
\hline $\begin{array}{l}\text { New revenue stream that } \\
\text { supports SWM (e.g., fees, } \\
\text { discounts, charges/fines) }\end{array}$ & Yes & Yes & Study & Study & Yes & & & \\
\hline $\begin{array}{l}\text { Supporting or requiring } \\
\text { developments to meet green } \\
\text { standards \& guidelines (e.g., } \\
\text { LEED) }\end{array}$ & Yes & & Yes & Yes & Yes & & LEED & LEED \\
\hline Other & $\begin{array}{l}\text { Street } \\
\text { trees } \\
(200) \\
\end{array}$ & $\begin{array}{l}\text { Success } \\
\text { of Pilot } \\
\text { projects }\end{array}$ & $\begin{array}{l}\text { OP \& } \\
\text { council } \\
\text { motion }\end{array}$ & $\begin{array}{l}\text { Rapid } \\
\text { growth }\end{array}$ & & $\begin{array}{l}\text { Faster } \\
\text { reviews }\end{array}$ & & \\
\hline
\end{tabular}

The interview questions also explored what types of GSI projects, policies, and technologies were piloted or were adopted by both the municipalities and private developers alike. When compared through a matrix (Table 9), a few GSI technologies appeared to be common amongst all others as either piloted or adopted such as permeable pavers, stormwater retention ponds, and street trees. 
CHAPTER 4: STATE OF PRACTICE FOR GSI POLICIES \& PROGRAMS

STORMWATER MANAGEMENT: ONTARIO MUNICIPAL POLICIES FOR GREEN INFRASTRUCTURE

The use of bioswales appeared to be an emerging GSI technology that was either adopted or is being piloted. Aside from those trends, the interviews revealed that municipalities faced different conditions, technical, political or educational which influenced the type of GSI technology selected.

Table 9: Types of GSI Projects Adopted by Municipalities for SWM (Interviewee Responses)

\begin{tabular}{|c|c|c|c|c|c|c|c|c|}
\hline $\begin{array}{l}\text { What type of Green Stormwater } \\
\text { Infrastructure (GSI) projects has } \\
\text { your municipality reviewed and/or } \\
\text { adopted for its program to support } \\
\text { stormwater management (SWM)? }\end{array}$ & 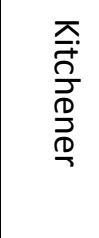 & 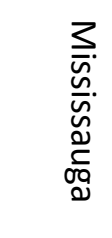 & $\begin{array}{l}-1 \\
\text { 웅 } \\
0 \\
0 \\
0\end{array}$ & 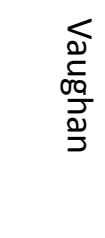 & 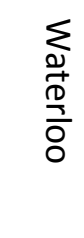 & 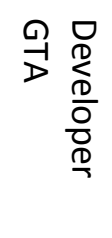 & 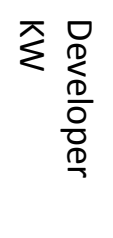 & 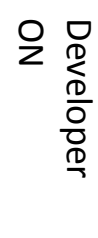 \\
\hline Bioswales & Pilot & Yes & Pilot & Pilot & Yes & Yes & Yes & Yes \\
\hline $\begin{array}{l}\text { Bump-Outs with GSI integrated in the } \\
\text { design }\end{array}$ & & Yes & Study & & Yes & & & Yes \\
\hline $\begin{array}{l}\text { Downspout Disconnection (DD) \& Rain } \\
\text { Barrels (RB) }\end{array}$ & & RB & $\begin{array}{l}\mathrm{RB}, \\
\mathrm{DD}\end{array}$ & & $\mathrm{RB}$ & & & \\
\hline $\begin{array}{l}\text { Fees } \& \text { Credit system for impermeable } \\
\text { surface areas }\end{array}$ & $\mathrm{F}+\mathrm{C}$ & $\mathrm{F}+\mathrm{C}$ & $\begin{array}{l}\text { Study, } \\
\text { Fee }\end{array}$ & & $\mathrm{F}+\mathrm{C}$ & & Credit & $\mathrm{F}+\mathrm{C}$ \\
\hline $\begin{array}{l}\text { Permeable Pavers/Pavements or Porous } \\
\text { Concrete }\end{array}$ & Yes & Yes & Pilot & Pilot & Few & Yes & Yes & Yes \\
\hline Rain Gardens / Bioretention Planters & Yes & & Pilot & & Yes & Yes & Yes & Pilot \\
\hline Street Trees & & Yes & Yes & & Yes & Yes & & \\
\hline Green Roofs & & & Yes & Yes & & Yes & Pilot & Yes \\
\hline $\begin{array}{l}\text { Stormwater retention ponds \& parks } \\
\text { (integrated park design) }\end{array}$ & Yes & & Yes & Yes & Yes & Yes & Yes & \\
\hline $\begin{array}{l}\text { Other (e.g., rebates for GSI, DC discount, } \\
\text { Oil \& Grit separator) }\end{array}$ & $\begin{array}{l}\text { O\&G } \\
\text { ROW }\end{array}$ & & $\begin{array}{l}20 \% \\
D C\end{array}$ & & & & $\begin{array}{l}\text { Rain } \\
\text { reuse }\end{array}$ & \\
\hline
\end{tabular}

The common element to each of these GSI was the real or perceived ease with maintenance.

For instance, In Mississauga, every public ROW is being reviewed for potential to include bump-out with GSI, as part of the Green Development Strategy. In addition, TRCA is conducting a neighbourhood study for sustainable neighbourhood retrofit program (i.e., Burnhamthorpe SNAP), where GSI can be installed. A preference emerged for private property GSI with mostly permeable pavers, with a rationale associated to the higher maintenance with bioswales and green roofs. This sentiment was echoed by a couple of the developers with their initial attempts at building with green roofs. In Toronto, there area numerous green roofs installed on high-rise developments pursuing LEED and through TGS Tier I compliance and Tier II voluntary standards. The green roof installations were initially complex with a 
CHAPTER 4: STATE OF PRACTICE FOR GSI POLICIES \& PROGRAMS

STORMWATER MANAGEMENT: ONTARIO MUNICIPAL POLICIES FOR GREEN INFRASTRUCTURE

number of supporting technologies attempted, such as filter mats and high growth media, to additional infrastructure that can retain and divert and reuse more rainwater. In general, a green roof with greater soil depth retains more moisture for healthy plant growth and provides an opportunity for increased biodiversity with plant material for stormwater retention.

Where as in Waterloo, Green Roofs only qualified for non-residential properties, and was not examined for high-rise or mid-rise residential, which is a trend in Waterloo's new real estate environment, and is seen as an opportunity lost for GSI. The most common LID practice adopted are infiltration trench facilities which are used extensively to meet groundwater recharge requirements, because of the environmentally sensitive nature of lands to the west. The city encourages any SWM control from a downspout disconnection, and awards a stormwater credit rewarded. The City has 65 stormwater ponds and is looking to add more.

From the interviews, private sector developers considered green were open to testing a new approach that is environmentally sustainable, as GSI became part of the equation for new development plans, with the cost and effort accounted for in the development budget. It was noted that the type of GSI selected varied based on access to experts, skilled contractors and engineers to build, design, monitor, and maintain these LIDs is important. The key then became for the builders to translate the GSI savings to a reduction of condo capital plans and maintenance budgets. When considering retrofit projects with GSI, developers found these to be most feasible on larger sites with a stormwater credit. For a smaller site, a credit is insignificant compared to the costs and the pay-back is too long.

Tracking of GSI technologies and programs has been employed by only a small number of the municipalities, primarily those with a stormwater fee that requires supporting accounting measures. A centralized database was the most effective, efficient and adaptable method for tracking the performance, location and type of GSI, which was easily managed through dedicated staff. If the municipality has adopted a stormwater credit, a mechanism can be built it to track the performance of 
CHAPTER 4: STATE OF PRACTICE FOR GSI POLICIES \& PROGRAMS

STORMWATER MANAGEMENT: ONTARIO MUNICIPAL POLICIES FOR GREEN INFRASTRUCTURE

the units, so that they will continue to meet their design objectives and were tied into requirements for ongoing annual maintenance. For instance, the City of Kitchener required all GSI to be regularly cleaned from a trained or certified technician/contractor, which ensures its longevity and the success of the GSI program. Certification mechanisms can ensure that the contractors' knowledge base is kept up-to-date with new trends, policies, and technologies.

Where a fee program is not in place, tracking was more labor intensive and difficult to monitor all the new public and private GSI installations. For example, the Green Streets staff in Toronto are tracking the performance of constructed pilot projects with periodic visual monitoring, and are including designs for more elaborate remote sensing monitoring systems on proposed pilot projects. To complicate matters, installations have not been reviewed if on private sites, or if contract out by other departments, such as Parks \& Forestry and TPA Green P lots, who are championing their own sites.

The adoption of a GSI policy is very complicated, with funding identified as major barrier identified earlier in Chapter 4.1 through all of the elements under the two overarching categories related to (a) Policy, Coordination, \& Communication barriers; and (b) Capacity, Design, \& Financing barriers. The interview responses and literature review both confirmed that GSI is a preferred option for SWM, however to take these technologies to wide spread adoption and to manage them, a new funding mechanism was the solution through a stormwater charge. Three of the municipalities adopted similar financing models (described earlier in Chapter 3.4), while the Cities of Toronto and Vaughan are currently undertaking a study to explore what model for a stormwater charge and/or credit would be the right fit for their municipality.

Building a case for the development of policies and adoption of standards and a stormwater charge was instrumental to adoption (refer to the call out boxes for examples of how the municipal policies influenced decisions). 
An Existing Stormwater Charge: In the downtown core of the City of Kitchener, Victoria Park Lake, is viewed as crown jewel, with a large upstream drainage area that filled up with sediment over time. The city needed a funding mechanism to cover the cost of dredging and remediation, which was the driver to start thinking about different funding mechanisms. Prior to developing its stormwater charge, the City reviewed the amount of impervious area which projected costs and location to add grey infrastructure for SWM through new ponds. A case was made for implementing 200 "green streets" with GSI in the ROW as a natural, effective and more feasible solution to achieve the SWM objectives. As a best practice, Kitchener's undertook a Watershed Study which provided a more balanced approach to meet water quality and quantity targets. Source Watershed Protection is reviewing GSI as a long-term solution, as over $1 / 3$ of the city falls within wellhead protection areas. This requires a significant amount of will and data-driven (evidence based) results to validate the current design capacity.

An Ongoing Study for a new Stormwater Charge: The City of Vaughan is expanding rapidly and requires a new SWM funding strategy to meet the city wide SWM controls, which would cost approx. \$50M through conventional approaches. The SWM Master Plan has recommended infrastructure and controls that would provide protection beyond the minimum $15 \%$ landscape area of the Secondary Plan, and must account for water quality, quantity, erosion, and balance (City of Vaughan, 2014). A new strategy for a stormwater charge replaces traditional funding models with DC and property tax through a Stormwater Infrastructure Funding Study (City of Vaughan, 2016).

Another approach to addressing funding gaps was explored by reviewing a case for GSI installations through a public-private-partnership (P3) model. Given that water is not limited to a boundary, and that GSI such as street trees along the ROW or on private property serve the same purpose of addressing stormwater, an question was asked as to the experiences with P3 models for GSI. 
CHAPTER 4: STATE OF PRACTICE FOR GSI POLICIES \& PROGRAMS

STORMWATER MANAGEMENT: ONTARIO MUNICIPAL POLICIES FOR GREEN INFRASTRUCTURE

The interview responses did not reveal any clear trend in practice with some municipalities having

funded GSI installations on private properties, which are then maintained and monitored by third party

groups, while other municipalities shied away from installation that cross over property boundaries.

Further research is required on P3 opportunities for GSI with private stakeholders (developers and

property managers). Responses from private land developers affirmed their adoption of GSI was driven

by municipal policies $\&$ strategies, and the provision of incentives and discounts (Table below).

Table 11: GSI Policies, strategies, \& tools for Municipal adoption (interviewee responses)

\begin{tabular}{|c|c|c|c|c|c|c|c|c|}
\hline $\begin{array}{l}\text { What policies, } \\
\text { strategies and/or } \\
\text { tools has your } \\
\text { municipality adopted } \\
\text { or is considering to } \\
\text { increase } \\
\text { implementation? }\end{array}$ & $\begin{array}{l}\text { 줗 } \\
\stackrel{3}{\vec{D}} \\
\stackrel{D}{D} \\
\text { D্ }\end{array}$ & 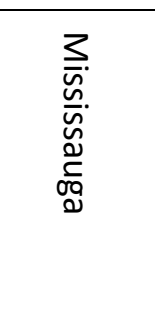 & 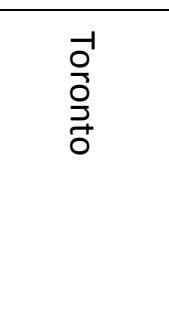 & 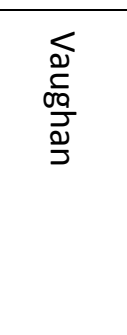 & 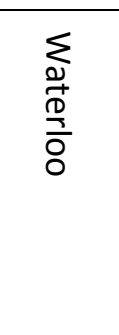 & 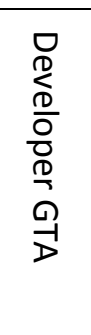 & $\begin{array}{l}\frac{D}{D} \\
\stackrel{D}{D} \\
\frac{D}{O} \\
\frac{D}{D} \\
\frac{D}{C} \\
\frac{\lambda}{\Sigma}\end{array}$ & $\begin{array}{l}\text { D } \\
\stackrel{D}{D} \\
\frac{D}{0} \\
\frac{O}{0} \\
\frac{D}{1} \\
0 \\
\frac{0}{Z}\end{array}$ \\
\hline $\begin{array}{l}\text { a) Education, training, } \\
\text { outreach; and } \\
\text { supporting } \\
\text { guidelines \& } \\
\text { strategies for } \\
\text { implementation } \\
\end{array}$ & $\begin{array}{l}\text { Yes, Smart } \\
\text { for Salt }\end{array}$ & & $\begin{array}{l}\text { Education } \\
\text { Strategy, } \\
\text { TGS, } \\
\text { Green } \\
\text { Streets }\end{array}$ & & $\begin{array}{l}\text { Admin. } \\
\text { Utility }\end{array}$ & Yes & Yes & $\begin{array}{l}\text { Yes, } \\
\text { some } \\
\text { Mun. }\end{array}$ \\
\hline $\begin{array}{l}\text { b) Fees and Credit for } \\
\text { impermeable } \\
\text { surface areas / } \\
\text { property size }\end{array}$ & $\mathrm{F}+\mathrm{C}$ tiered & Fee flat & $\begin{array}{l}\text { Study of } \\
\text { Fee } \\
\text { (flat) }\end{array}$ & $\begin{array}{l}\text { Study } \\
\text { of Fee } \\
\text { (tiered) }\end{array}$ & $\begin{array}{l}\mathrm{F}+\mathrm{C} \\
\text { tiered }\end{array}$ & & $\begin{array}{l}\text { Yes, } \\
\text { credit }\end{array}$ & \\
\hline $\begin{array}{l}\text { c) Incentives/discounts } \\
\text { to Development } \\
\text { Charge, or increase } \\
\text { permeable surface } \\
\text { areas }\end{array}$ & $\begin{array}{l}\text { Credit + } \\
\text { Enforcement }\end{array}$ & Credit & $\begin{array}{l}\text { DC } 20 \% \\
\text { TGS }\end{array}$ & Review & & & & $\begin{array}{l}\text { TGS } \\
20 \% \\
\text { DC }\end{array}$ \\
\hline $\begin{array}{l}\text { d) Stewardship models } \\
\text { with community } \\
\text { groups or private } \\
\text { owners } \\
\text { (condominiums) }\end{array}$ & Yes (REEP) & $\begin{array}{l}\text { Yes, } \\
\text { proactive } \\
\& \\
\text { reactive }\end{array}$ & Yes & & & Trees & & LEED \\
\hline e) Other & & & & $\begin{array}{l}\text { Urban } \\
\text { design }\end{array}$ & & & Awards & \\
\hline
\end{tabular}


Policy \& Design Standards for Private Developers: In the City of Toronto, the Wet Weather

Flow Management Plan (WWFMP) provides the policy to manage water at its source, with a focus on water quality. For the ROW, the City is developing an implementation strategy for GSI through a Green Streets Standards, which will specify how to design, construct and manage GSI in the ROW. The Toronto Parking Authority currently uses LID design measures in its new construction work, which are consistent with its Urban Design Guidelines for Greening Surface Parking Lots. The City will review all the new construction standards against the guidance also being developed by MOECC.

All new development applications are required to meet minimum standards on approvals guidance is provided under the Toronto Green Standards $(\mathrm{TGS})^{15}$, required under Toronto's Official Plan as the key policy for land use planning and development. The TGS is a strong policy tool for the private sector to install GSI, which would also capture reporting for Zoning By-Laws Amendments; Draft Plans for Sub-Divisions; Draft Plans for Condominium Developments; and Site Plan Controls. The TGS is a new two-tier system for compliance and voluntary measurements launched in 2010, primarily seen as a pilot to determine the effectiveness of policy measures on sustainability reporting (Stott, S., 2015, personal communication). The Tier I TGS is a minimum compliance standard for stormwater runoff retention on new development applications only, where the cost is borne by the developer. The Tier II TGS provides an incentive for higher LID measures through a $20 \%$ discount on the DC. This costs may ultimately be borne by the end-consumer based on the carrying capacity of the market.

A common practice revealed by both the developers and municipalities revolved around the requirements and various mechanisms utilized for outreach, education and training. All the

15 TGS promotes sustainable site and building designs to address urban environmental pressures: air quality, climate change and energy efficiency, water quality and efficiency, ecology and solid waste. A detailed SWM report is required with applications along with a TGS checklist (City of Toronto, 2013). 
CHAPTER 4: STATE OF PRACTICE FOR GSI POLICIES \& PROGRAMS

STORMWATER MANAGEMENT: ONTARIO MUNICIPAL POLICIES FOR GREEN INFRASTRUCTURE

respondents emphasized the need for ongoing education, with communication being essential. A need

for formalized training for staff, councillors, and practitioners was high. For some, education was iterative over time working with academia, municipalities, and consultants. As the new standards for GSI in the public ROW are finalized in Toronto, there will be a need to support the growing industry with formalized structured training. For managers, municipal planners, and developers there is an existing network of experts, authorities, practitioners and municipal staff that are sharing their experiences and resources, which is advancing the practice and creating a culture of knowledge.

Table 13: Example of Policies for GSI Education \& Training

Policy for requiring Education \& Training: Training is outlined through the Master Plan process in the City of Kitchener. Internal staff attend educational seminars and workshops to be able to provide direction of the SWM policies, LID technologies, and engage with external service providers. Community outreach is coordinated through an external non-government organization, REEP, with targets to meet annually. REEP green solutions is an NGO, under Green Communities Canada, that engages the community to increase awareness, in cooperation with the City. It runs seminars, rain barrel drives, visits to rate payers and industry, with joint funding from the City and MOECC.

The quality of water and stormwater in particular is concerned with road salt. The municipality established policies for a certified roster, "Smart about Salt", with an annual certification program. To remain eligible for stormwater credit, annual inspection and maintenance is required through a certified professional program managed by the City's Stormwater Utility.

Public outreach and education programs is a good practice, along with online tools and sharing of resources as a favoured approach. Support on this front has been integral for the advancement of GSI with Conservation Authorities and NGOs at front and centre in southern Ontario. The full set of responses to all the interview questions is available in Appendix $E$. 
CHAPTER 4: STATE OF PRACTICE FOR GSI POLICIES \& PROGRAMS

STORMWATER MANAGEMENT: ONTARIO MUNICIPAL POLICIES FOR GREEN INFRASTRUCTURE

\subsection{Best Practices \& Lessons Learned}

Through a combination of interview responses and background literature, a series of best

practices and lessons learned were uncovered, one single approach resonated with all the municipalities

for implementation and management of a municipal GSI policy or structure, being the adoption of a new financing model to fund the capital for GSI installations and operate a sustainable budget for a GSI

program. Responses to the interview questions revealed the following best practices:

There is a need for continued learning opportunities to keep up with the evolving practice and policies around GSI. Individuals and organizations are very motivated to stay abreast of the changes and industry best practices. A continued culture of knowledge sharing, currently led by the Conservation Authorities, LID practitioners, Provincial and Municipal Governments is instrumental for municipalities and practitioners at the early stage of adoption to learn from each other and recognize good practices and experiences. It is equally important for the municipality to keep the communication open to the public with knowledge of their GSI initiatives through an approach that covers as many angles and audiences as possible. A single-designated access point and dedicated staff resources will help to ensure open communication, outreach, education and training is maintained. The performance and GSI unit tracking should be consistent amongst the municipalities with stormwater fees and credit systems through a centralized database and along with GIS mapping it will provide up to date information for organizations and CAs to plan on a watershed basis.

A municipality is normally associated with department silos and has typically not been a strong body of knowledge on SWM and GI, or an environment where departments willingly interact and share. But by creating a new SWM Utility as a large cross-departmental program, it invited other department staff to participate. It is important to have staff at the municipality who are interested in GI working at the utility. A coordinated approach is required to integrate Council priorities for sustainable urban design, and emerging principles for SWM in term of LIDs. A Working Group can be established, with 
CHAPTER 4: STATE OF PRACTICE FOR GSI POLICIES \& PROGRAMS

STORMWATER MANAGEMENT: ONTARIO MUNICIPAL POLICIES FOR GREEN INFRASTRUCTURE

members of all the relevant departments from Policy, Design, Implementation and Monitoring and

Maintenance. This group should be coordinated, centralized and could integrate GSI.

A stormwater charge is an important step towards a funding mechanism that is essential for delivering and operating a sustainable SWM plan, as a program and budget is required for any departmental changes. Cities should review both a stormwater charge and credit program which would not only fund the program, but create an incentive for private investments in GSI.

Planning for changes ahead of Provincial Policy was revealed to be beneficial, as the City was prepared for more stringent compliance standards. Working under guidance of the legislative standards from Conservation Authorities, a City can set voluntary standards, which will be consistent with the upcoming MOE guidance manual for LID. The development of new standards through a collaborative approach is important as it will be applicable to both capital works projects and private developments through the site plan approval, creating a standardized approach to GSI. It will have a top-down approach which is necessary for wide-spread adoption and will provide clear direction to the development community and staff alike. A lesson learned from developing incentives and subsidies is to consider potential future opportunities by looking at other cities.

Developing for high-rise residential land use in Toronto with GSI is very challenging, as there are a number of locations where a developer may want to put in GSI, but what may be complications with the subsurface. In addition to the technical challenges, there are management and operational constraints faced if a developer were to install LID technologies and the condo board that takes over does not commit the resources for regular and specialized maintenance associated with the common elements such as landscaping. For retrofits, GSI was found to be more feasible on larger properties, as a cost-benefit analysis indicate the GSI retrofit can create a significant credit based on the building lot.

A final best practice is to present a high-level view which can meet the objectives of everyone in the long term, will avoid unnecessary objections, where any one can stop or delay a project. 
CHAPTER 5: CONCLUSION \& RECOMMENDATIONS

STORMWATER MANAGEMENT: ONTARIO MUNICIPAL POLICIES FOR GREEN INFRASTRUCTURE

\section{CONCLUSION \& RECOMMENDATIONS}

\subsection{Conclusion}

Municipalities and other stakeholders have rediscovered that prevention offers the greatest potential to mitigate flooding and the associated damage to the environment, society and economy. The research demonstrated the benefits of green stormwater infrastructure (GSI), its policies and new financial models applicable to Ontario municipalities that will serve the public interest by resolving issues of flooding, reducing costs, balancing social inequities of flood victims, increasing efficiency and capacity of municipal wastewater services, and providing a fairer mechanism to pay for the stormwater service by those that impact it the greatest.

The study provided a comprehensive review of applicable policies, finance mechanisms, state of practice, and obtained the perspectives from representatives of five municipalities and three private sector developers across southern Ontario with experience of green stormwater infrastructure policies in the right-of-way and low impact developments on private lands. The state of the industry has advanced from innovators to early adopters, and the key stakeholders, public, council and government staff are comfortable with supporting the adoption of green infrastructure to manage stormwater.

The findings uncovered the known barriers to adoption of GSI and presented a number of solutions that have been attempted by the industry, which were compared and analyzed through the experiences of five leading municipalities and three private developers in Southern Ontario that highlighted best practices and lessons learned. From the range of solutions and best practices presented, a pattern emerged as next steps for assisting the adoption of municipal policies for green infrastructure and low impact development to manage stormwater. Five key recommendations are provided to transform the practice so that it "becomes business as usual". 
CHAPTER 5: CONCLUSION \& RECOMMENDATIONS

STORMWATER MANAGEMENT: ONTARIO MUNICIPAL POLICIES FOR GREEN INFRASTRUCTURE

\subsection{Recommendations}

\section{Prepare a Green Stormwater Infrastructure Policies}

A high-level policy should set a framework on how the municipality will manage rain where it falls and address the public interest through flooding prevention with green stormwater infrastructure (GSI) in the public-right-of-way and through principles of Low Impact Development (LID) on property and building design. The City should set high voluntary standards; integrate sustainable "urban design" with GSI and Green Streets; and prioritize a coordinated approach of capital projects to integrate GI, and leverage opportunities to be prepared for future changes in extreme weather events, associated with climate change. The policies can call for a strategy and implementation plan to mitigate the flooding (basement, street or riverine) by establishing a source of funds and other necessary resources.

\section{Adopt a Finance Model that is the Right Fit}

The research findings have demonstrated that there are a number of options being explored by different municipalities, and that there is no "silver bullet" or "one-size-fits-all" approach. The study has revealed that a new financing model is required for green stormwater infrastructure. Each municipality in this study has either implemented or is in the process of reviewing such a model for a stormwater charge to create a dedicated revenue stream. Two options were presented, which include a flat fee by property type, and a tiered flat fee by property type and size. When combined with the stormwater credit, it will adjust for the amount of actual impervious area, allow for a phased in approach. The Development Charges for new development applications, along with DC discounts for achieving higher than the minimum base Green Standard is a strong incentive to achieving higher standards on new building developments, and can further be refined to reflect GSI.

\section{Create an Inter-Disciplinary GSI Team in a dedicated unit or utility}

The common thread from all case studies was the inter-disciplinary teams and collaborative approach with representatives across departments to develop and implement an integrated GSI policy 
CHAPTER 5: CONCLUSION \& RECOMMENDATIONS

STORMWATER MANAGEMENT: ONTARIO MUNICIPAL POLICIES FOR GREEN INFRASTRUCTURE

and program that makes best use of available resources through new policies for adoption, funding, and operations and maintenance. A coordinated approach is required to integrate Council priorities for sustainable urban design, and emerging principles for SWM in term of LIDs. In terms of providing the necessary foundation to successfully fund and carry out new GSI installations and to monitor and manage all the public as well as private installations in a municipality, there is a case to be made for assigning one responsible department or if possible creating a new unique new entity, like a Stormwater Utility.

\section{Foster a Culture of Knowledge Sharing}

There is a need for continued learning opportunities to keep up with the evolving practice and policies around GSI. Supporting and participating in knowledge sharing is equally important for the municipality to keep the communication open to the public with knowledge of their GSI initiatives through an approach that covers as many angles and audiences as possible. A single-designated access point and dedicated staff resources will help to ensure open communication, outreach, education and training is maintained. Community engagement and the interested public should be included within this circle. The solutions are for the people, and people are part of the solution through community stewardship and local sharing of knowledge on what green infrastructure is theirs. Key organizations in supporting the culture of knowledge of LID and GI for SWM include the Credit Valley Conservation, the Toronto and Region Conservation Authority, and Green Communities Canada. 


\section{Appendix A: Ethics Approval for Research}

The research topic and method received approval from the Research Ethics Board (REB) at

Ryerson University, prior to commencement of any primary research.

\section{Ryerson Ethics Board}

To: Wayne Coutinho

School of Urban and Regional Planning

Re: REB 2015-385: Study of Municipal Green Stormwater Infrastructure Policies across Canada for localized Storm-Water Management

Date: February 2, 2016

Dear Wayne Coutinho,

The review of your protocol REB File REB 2015-385 is now complete. The project has been approved for a one year period. Please note that before proceeding with your project, compliance with other required University approvals/certifications, institutional requirements, or governmental authorizations may be required.

This approval may be extended after one year upon request. Please be advised that if the project is not renewed, approval will expire and no more research involving humans may take place. If this is a funded project, access to research funds may also be affected.

Please note that REB approval policies require that you adhere strictly to the protocol as last reviewed by the REB and that any modifications must be approved by the Board before they can be implemented. Adverse or unexpected events must be reported to the REB as soon as possible with an indication from the Principal Investigator as to how, in the view of the Principal Investigator, these events affect the continuation of the protocol.

Finally, if research subjects are in the care of a health facility, at a school, or other institution or community organization, it is the responsibility of the Principal Investigator to ensure that the ethical guidelines and approvals of those facilities or institutions are obtained and filed with the REB prior to the initiation of any research.

Please quote your REB file number (REB 2015-385) on future correspondence.

Congratulations and best of luck in conducting your research.

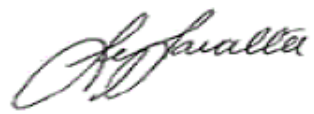

Lynn Lavallée, Ph.D.

Chair, Research Ethics Board 


\section{Appendix B: Consent Agreement \& Correspondence with Interviewees}

\section{Ryerson}

University

\section{Ryerson University Consent Agreement}

You are being invited to participate in a research study. Please read this consent form so that you understand what your participation will involve. Before you consent to participate, please ask any questions to be sure you understand what your participation will involve.

\section{STUDY OF MUNICIPAL GOVERNMENT POLICIES ON GREEN STORMWATER INFRASTRUCTURE FOR LOCALIZED STORM-WATER MANAGEMENT}

INVESTIGATORS: This research study is being conducted by Wayne Coutinho from the School of Urban and Regional Planning at Ryerson University.

If you have any questions or concerns about the research, please feel free to contact:

Wayne Coutinho, Senior Student, Master of Planning Program, School of Urban and Regional Planning, Ryerson University wayne.coutinho@ryerson.ca

Supervisor: Dr. Nina-Marie Lister Graduate Programme Director; Associate Professor School of Urban and Regional Planning, Ryerson University

The researcher is a graduate student, with the results of the study contributing to a senior Master of Planning Research Project required as part of the program.

PURPOSE OF THE STUDY: This study will evaluate municipal government programs, policies and tools for green stormwater management (GSI), in medium-to-large Canadian Cities. The goal is to identify best practices and/or lessons learned, that may support a rationale for stronger municipal standards, guidelines and incentives for local GSI to be applied for private developments and in the public right-of-way.

- Key Staff/Managers responsible of GSI programs from 5 medium-to-large Canadian municipalities are being recruited for this study.

- The eligibility criteria for participants are staff responsible and knowledgeable to discuss GSI that are in place or are in the process of being adopted.

- Following the interviews with municipal staff, potential projects involving GSI from new developments that have implemented the municipal programs will be researched for interviews from the private sector to gauge their perspective of GSI programs/policies.

WHAT PARTICIPATION MEANS: If you volunteer to participate in this study, you will be asked to do the following things: 
Interview Set-up and Consent:

- $\quad$ Read the consent form and recruitment letter, and provide consent in writing (email) prior to participation in the telephone interview.

- Provide a time and date for participating in the telephone interview that is convenient to yourself, within regular business hours. You will be expected to participate in a series of seven exploratory questions that should take no more than one hour of your time.

- Should you be unable to participate at the set date/time, you will be requested to notify the researcher and provide alternate dates/time to reschedule the interview at the next available date/time for yourself and the researcher.

Interview Participation:

- Prior to the telephone interview, the questions will be emailed at least 24 hours in advance, to aid in preparation and provide you with a reminder.

- During the telephone interview, you will be requested to respond to the questions. Although the questions will be posed in a logical order, you are encouraged to relay your knowledge in the style or format and order in with which you are most comfortable with.

- The telephone interviews will be audio-recorded on a password-protected device to ensure accuracy.

- You may be requested to share additional materials and information that would assist in the research, such as municipal reports and leads.

- As a knowledgeable and active member in this field familiar with projects in your jurisdiction, you may be able to provide leads from the private sector for telephone interview to support the research of GSI as implemented on private sector developments.

- Sample questions include:

o What were the main drivers for adopting or piloting a program that promotes, requires and/or advocates Green Stormwater Infrastructure? $\circ$ What are some lessons learned in piloting this program and/or implementing it as new program in your municipality?

A summary of the best practices and/or compendium of the case studies will be made available to participants and provided by email following the completion of the report if requested.

POTENTIAL BENEFITS: Please note that as a participant, you will not directly benefit from participating in the study. The intent of the research is to highlight best practices, including policy and government intervention, that benefits the public interest, which includes flooding mitigation, water quality, environmental protection, municipal asset management and associated social and health benefits. The result findings and report may be shared with participants, published in a Journal and/or shared with municipal governments. The research may indicate that there is need for government intervention in the form of funding and policy which may possibly result in providing support towards a certain industry or sector that requires assistance to implement the GSI. I cannot guarantee any of these benefits as a direct result from this study. 
POTENTIAL RISKS TO YOU AS A PARTICIPANT: The potential risks are low, and may include having your identity revealed through role association with a particular case study. A risk of comparison of performance against other municipal programs, may also be seen unfavourable to your organization.

- Information on municipal programs and pilots is public available or accessible through a freedom of information request.

- Furthermore, as this industry is relatively new in Canada, a knowledgeable reader may be able associate an obstacle, challenge or best practice to a particular project/site and thus the organization and the individual(s) with related roles or responsibilities. The risk of potential identification will be minimized by not associating lessons learned from case studies with a particular project or municipality. Exceptions to this procedure, will only be made when the information is publicly available and/or the participant elects to having that information associated with their program or project shared.

You may choose not to answer a particular question that causes discomfort (you may skip any question). You may choose to opt-out of the question or interview at any time. Any of the information/data that you provided will be destroyed upon your request.

CONFIDENTIALITY: The participants will be known to the researcher and my supervisor. In order to protect identities, general references will be made to all case studies in terms of lessons learned. Pseudonyms will be used where the interviewee indicate that they do not want to be identified or associated to a particular comment, but acknowledges the information should be included in the research results. Participants are asked to indicate their preference of whether or not their real name is used in published material as a source of information. A check-box on the signatory page for participants to opt in or out of having your name published. Where the participants are public points of contact, they may wish to have their information provided, works/program referenced, and or comments quoted as requested.

The researcher, Wayne Coutinho, and the supervisor, Dr. Nina-Marie Lister, from Ryerson University will have access to the research data and findings. Peer review of the MRP report, will be provided by a second reader who has been screened by the supervisor.

Information will be retained for a period of five years and will be destroyed/erased following this period. Security will be maintained through password protected data storage devices. Data collected will include: signed consent forms, transcripts of the interviews, and supporting information as provided by the participants on the practices, policies and measures utilized. Participant interviews are to be audio-recorded with an electronic device. The participant has the right to review/edit the recordings or transcripts. The recordings will be used for educational purposes only, and will be destroyed once the transcripts are created.

INCENTIVES FOR PARTICIPATION: There are no financial incentives or rewards offered for participation in this study.

COSTS TO PARTICIPATION: There are no costs to participation in this research.

VOLUNTARY PARTICIPATION AND WITHDRAWAL: Participation in this study is completely voluntary. You can choose whether to be in this study or not. If any question makes you uncomfortable, you can skip that question. If you choose to stop participating, you may also choose to not have your 
data included in the study. Your choice of whether or not to participate will not influence your future relations with Ryerson University or the investigator, Wayne Coutinho, or the supervisor, Prof. Lister, involved in the research.

QUESTIONS ABOUT THE STUDY: If you have any questions about the research now, please ask. If you have questions later about the research, you may contact.

If you have any questions or concerns about the research, please feel free to contact:

Primary Investigator: Wayne Coutinho,

Student, Master of Planning Program,

School of Urban and Regional Planning, Ryerson University wayne.coutinho@ryerson.ca

Supervisor: Dr. Nina-Marie Lister

Graduate Programme Director; Associate Professor

School of Urban and Regional Planning, Ryerson University

350 Victoria Street, SBB 420, Toronto, Ontario, Canada, M5B 2K3

Office. $416.979 .5000 \times 6769$

nm.lister@ryerson.ca

This study has been reviewed by the Ryerson University Research Ethics Board. If you have questions regarding your rights as a participant in this study, please contact:

Research Ethics Board

c/o Office of the Vice President, Research and Innovation

Ryerson University

350 Victoria Street

Toronto, ON M5B 2K3

416-979-5042

rebchair@ryerson.ca 
Appendix C: List of Interviewees

Table 14: List of Interviewees

\begin{tabular}{|c|c|c|c|}
\hline Representative & Title / Position & Organization & Department \\
\hline Wilson, Matt & $\begin{array}{l}\text { Design and } \\
\text { Construction Project } \\
\text { Manager }\end{array}$ & City of Kitchener & Stormwater Utility \\
\hline Ahmad, Muneef & $\begin{array}{l}\text { Water Resources } \\
\text { Engineering }\end{array}$ & City of Mississauga & $\begin{array}{l}\text { Transportation and } \\
\text { Works }\end{array}$ \\
\hline Boudreau, Sheila & Urban Design & City of Toronto & City Planning \\
\hline Gerardo, Paez Alonso & $\begin{array}{l}\text { Urban Design } \\
\text { Landscape Architecture }\end{array}$ & City of Vaughan & Public Works \\
\hline Wilson, Moira & Senior Urban Designer & City of Vaughan & $\begin{array}{l}\text { Urban Design and } \\
\text { Cultural Heritage }\end{array}$ \\
\hline Yousef, Saad & $\begin{array}{l}\text { Storm Drainage } \\
\text { Engineer }\end{array}$ & City of Vaughan & Public Works \\
\hline Chapman, Todd & Manager of Programs & City of Waterloo & Water Services \\
\hline Anonymous* & $\begin{array}{l}\text { Principal, Urban } \\
\text { Planning \& Design }\end{array}$ & Developer in GTA & Land Development \\
\hline Anonymous* & Property Manager & $\begin{array}{l}\text { Developer in Waterloo } \\
\text { Region }\end{array}$ & Land Development \\
\hline Anonymous* & $\begin{array}{l}\text { Director, Conservation } \\
\text { \& Sustainable Design }\end{array}$ & $\begin{array}{l}\text { Developer in Southern } \\
\text { Ontario }\end{array}$ & Land Development \\
\hline Anonymous* & Manager, Innovation & $\begin{array}{l}\text { Developer in Southern } \\
\text { Ontario }\end{array}$ & Land Development \\
\hline
\end{tabular}

* Interviewees with representatives from private-sector land development and property management, who requested to remain anonymous. 


\section{Appendix D: Interview Questions for Municipal Government Representatives}

1. What type of Green Stormwater Infrastructure (GSI) projects has your municipality reviewed and/or adopted for its program to support stormwater management (SWM)?
a) Bioswales
b) Bump-Outs with GSI integrated in the design
c) Downspout Disconnection \& Rain Barrels
d) Fees \& Credit system for impermeable surface areas
e) Permeable Pavers/Pavements or Porous Concrete
f) Rain Gardens
g) Street Trees
h) Green Roofs
i) Stormwater retention ponds \& parks (integrated park design)
j) Other (e.g., rebates for purchasing GSI such as rain barrels)

2. What were the main drivers for adopting or piloting a program that promotes, requires and/or advocates Green Stormwater Infrastructure? Indicate all applicable.
a) Supporting Aging Grey Infrastructure
b) Negating the need for new end-of-pipe solutions or traditional conveyance controls
c) Mitigating or responding to localized flooding (basement, street, riverine)
d) Public space improvements (e.g., green space, parks, right-of-way)
e) Restoration or protection of waterways (discharge from combined sewer overflows)
f) Regulatory compliance (environmental quality, minimum standards,
g) Funding Incentives (federal, provincial, and local/regional government)
h) New revenue stream that supports SWM (e.g., fees, discounts, charges/fines, etc.)
i) Supporting or requiring new developments to meet green standards and guidelines

3. What policies, strategies and/or tools has your municipality adopted or is considering to increase implementation? Please explain rationale. Examples include:

- Guidelines \& Strategies for implementation

- Fees and Credit for impermeable surface areas / property size

- Incentives/discounts to Development Charge, or increase permeable surface areas.

- Stewardship models with community groups or private owners (condominiums)

4. How have these GSI installations in the public parks and right-of-way have been funded by the municipality or with the private sector through a public-private partnership model?

5. Has your municipality tracked the performance of the GSI installations, policies and instruments used? How? (e.g., number and type of installations, capital investments, operating budget, stormwater calculation for water infiltration/retention)?

6. What type of outreach, education and training is provided to internal staff, external service providers, stewardship groups, private-sector developers, and the general public?

7. What are some best practices or lessons learned that emerged from piloting GSI projects and/or implementing a new GSI program in your municipality? (i.e., what issues and opportunities should other municipalities considering GSI focus attention to?) 
APPENDIX E: RESPONSES TO INTERVIEW QUESTIONS

STORMWATER MANAGEMENT: ONTARIO MUNICIPAL POLICIES FOR GREEN INFRASTRUCTURE

\section{Appendix E: Responses to Interview Questions}

1. What type of Green Stormwater Infrastructure (GSI) projects has your municipality reviewed and/or adopted for its program to support stormwater management (SWM)?

- Kitchener: Prior to developing the Stormwater Charge and Credit, a consultant for the City made the case for implementing 200 "green streets" with GSI in the ROW as a more feasible solution for SWM than conventional end-of-pipe treatment. The review concluded that GI in the ROW is a natural and effective approach to SWM.

- Mississauga: Private GSI were mostly permeable pavers, because of higher maintenance with bioswales and green roofs. Every public ROW is being reviewed for potential to include bumpout with GSI, as part of the Green Development Strategy. TRCA is conducting a neighbourhood study and project for sustainable neighbourhood retrofit program (i.e., Burnhamthorpe SNAP).

- Toronto: The Green Street programs managed by Toronto Water and City Planning is currently developing technical guidelines and standards for GSI, that will be informed by the city's pilot projects to date. Some GI or LID installations have not been reviewed if on private sites, contract out by Parks \& Forestry, and through LID on TPA Green P lots, who are championing their own sites. Some GSI piloted are showing signs of wear due to heavy traffic turns at entrances, such as Porous Concrete at the Brick Works (designs should be reviewed for areas requiring stronger materials in some locations, until the performance of LID products improve).

- Vaughan: Every system is rapidly changing and being reviewed from all policy levels to make these more sustainable (recognition at an early stage with SWM).

- Waterloo: Infiltration trench facilities are used extensively to meet groundwater recharge requirements, because of the environmentally sensitive nature of lands to the west. The city encourages any SWM control from a downspout disconnection, and awards a stormwater credit rewarded (not just rain barrels). The City has 65 stormwater ponds and is looking to add more. Green Roofs only qualifies for non-residential properties, and was not examined for high-rise or mid-rise residential, unlike that of Toronto (lesson learned).

- Developer GTA: Testing a new approach that is environmentally sustainable, such as GSI, has become part of the equation. Having access to experts, skilled contractors and engineers to build, design, monitor, and maintain these LIDs is important. The key then becomes for the 
builders to translate the GI to a reduction of condo capital plans and maintenance budgets.

- Developer KW: Has reviewed retrofit projects with LID and GSI, but found these to be only feasible on large sites with the Stormwater credit. For a smaller site, the pay-back would take too long, as the credit would be insignificant compared to the costs. Other GI tested included a green roof, but will not pursue due to challenges for engineering retrofits on existing buildings, and maintenance requirements in particular with extremely dry weather conditions.

- Developer ON: Have tried new GSI with varying levels of cooperation with municipalities or the condo corporation. In one instance there was initial resistance due to concerns for maintenance, or the city did not want to provide a stormwater credit for the water balance. Education and persistence is important. In Toronto, a lot of green roofs were installed on high-rise pursuing LEED and with town houses. The green roof installations were initially complex, with various technologies attempted, some with filter mat, others with high growth media and infrastructure can retain and divert more water from storm systems. A green roof with greater soil depth retains more moisture for healthy plant growth (opportunities for increased biodiversity of plant material used), and stormwater retention.

2. What were the main drivers for adopting or piloting a program that promotes, requires and/or advocates Green Stormwater Infrastructure?

- Kitchener: In the downtown core, Victoria Park Lake, is viewed as crown jewel, with a large upstream drainage area that filled up with sediment over time. The city needed a funding mechanism to cover the cost of dredging and remediation, which was the driver to start thinking about different funding mechanism. Prior to the stormwater charge, a review of impervious area indicated the costs and location to add conventional SWM ponds would be too high and not feasible in built-up areas. Master Plan will manage rain where it falls. Watershed studies are a more balanced approach to meet water quality and quantity targets. This translates to using green infrastructure, with redevelopment of soft site as driver. Over $1 / 3$ of the city falls within wellhead protection areas. Source Watershed Protection areas are now looking at now using Green Infrastructure. In Moraine area there is a lot of infiltration, and SWM is looking into driving LID as a long-term solution. It takes a significant amount of will and data-driven (evidence based) results to validate if the amount of water in deep infiltration facilities will over the long term not meet their current design capacity. 
- Mississauga: Road project improvement was an initial driver as part of capital project improvement, which was pushed as priority following the 2013 extreme storm and flooding. Some ROW projects received funding from Tree Canada as well as Infrastructure stimulus funding, which funded the integrate LID design in the ROW. The City was piloting a number of GI demonstration projects prior to the 2013 storm. CVC was monitoring the pilots and was able to report back on performance of LID. The pilots were very successful, which led to council endorsing a resolution to look at all these measures on all the road projects.

- Toronto: Council was driven by the 2013 storm to question staff on how to build a resilient city that can survive extreme events, associated to climate change. The City had been faced with frequent basement and riverine flooding over the past 13 years. A significant investment is required to manage basement flooding issues across the city, which is estimated to continue escalating due to increasing severity of weather, aging infrastructure and increase impermeable surfaces of the urban environment. The Basement Flooding Protection Program reduces the risk of flooding during extreme storm events, and improves water quality.

- Vaughan: City is experiencing rapidly transformation from agricultural and suburban to urban downtown core, and it must build a sustainable city. Has Pilot projects and new initiatives that include LID for water management (stage of experimentation and exploration). The Master Plan for City was completed in 2014, with lot level controls for all soils, even those not conducive to permeability, which is very was forward thinking and ahead of MOE's LID manual to be released. The City is exploring a new SWM Funding Strategy (2016) for a stormwater charge, required for city wide SWM controls that would cost approx. $\$ 50 \mathrm{M}$. This new strategy would replace traditional funding models with DC and property tax.

- Waterloo: Establish a fairer funding mechanism through the stormwater charge and credit. By converting to user fee, there was a dedicated funding source to forecast revenues to plan for capital and operational needs for SWM. Can now schedule SWM pond cleanouts, which is a significant cost. In the west side development there is a large greenfield development with parts in an environmentally sensitive area, requiring wide-spread complex GSI through a trench and infiltration system.

- Developer GTA: Installing projects that are environmentally friendly could be used to leverage the political process to speed up approvals or to garnish a favour in City Hall at the political level. Increasing the marketability by telling a good story is a competitive advantage. 
APPENDIX E: RESPONSES TO INTERVIEW QUESTIONS

STORMWATER MANAGEMENT: ONTARIO MUNICIPAL POLICIES FOR GREEN INFRASTRUCTURE

- Developer KW: Corporate responsibility for new buildings to certify as LEED. Can attract quality tenants if you have a LEED Building.

- Developer ON: Commitment since mid-2000s to achieve LEED, but process is not as prescriptive for SWM. The challenge is in designing the SWM for meeting requirements which sometimes is not the same as LEED. The municipal requirements have some overlap.

3. What policies, strategies and/or tools has your municipality adopted or is considering to increase implementation?

- Kitchener: A high-level policy under review involves updating a Master Plan for GI, which sets a 15-year policy on SWM for the City. It will define how and where to manage SW. The City also requires design standards (tendering). The quality of water and stormwater in particular with salt is a major concern in Kitchener. The municipality established policies for a certified roster, "Smart about Salt", with an annual certification program. To remain eligible for stormwater credit, annual inspection and maintenance is required through a certified professional. REEP green solutions is an NGO, under Green Communities Canada, that engages the community to increase awareness, in cooperation with the City. It runs seminars, rain barrel drives, visits to rate payers and industry, with joint funding from the City and MOECC.

- Mississauga: The higher Green Development Strategy will encourage SWM on-site with GSI or LID. The push back from the private sector is low, likely due to timing, and a soft approach taken to communication the change far in advance, with a phased-in implementation for new development applications. Another likely reason for low resistance is that more than half the applications received are from a group of consultants, with technical knowledge and experience.

- Toronto: The Wet Weather Flow Management Plan (WWFMP) provides the policy to manage water at its source, with a focus on water quality. The City is developing implementation strategy for GSI through a Green Streets Standards, which will specify how to design, construct and manage GSI in the ROW. The Toronto Parking Authority uses LID design measures in new construction work, consistent with Urban Design "Guidelines for Greening Surface Parking Lots." The City will review our new construction standards against the guidance being developed by MOECC (it is understood that MOECC is not producing details at the level the Green Street Technical Guidelines). Toronto's Official Plan is a key policy for land use planning and building new projects with GI. A policy tool for private development is the Toronto Green Standards 
(TGS), which is a two-tier system for compliance and voluntary measurements. It provides an incentive for higher LID measures through a $20 \%$ discount on the DC.

- Vaughan: Council has set priorities to include sustainable "urban design", will create public spaces and focus on urban intensification areas, but requires integration of SWM through GI and LIDs. Source controls are added to site specific policy, such as the Steeles West district intensification corridor. It established a sustainability policy to include a minimum retention of $5 \mathrm{~mm}$ that will promote and include LID. Plus, development application tools. A new streetscape in the Vaughan Metro Centre, coined "Blue Street", is exploring LID within ROW.

- Waterloo: The key policy adopted is the Stormwater Charge and Credit, which is tiered for each property type and property size. The charge does not measure the impervious area, which allows for stronger implementation of the credit, rewarding properties that can demonstrate a decreased amount of impervious surfaces through LID, or higher infiltration and retention with GSI. Through the site plan application process, SWM controls with GI are "encouraged" if they meet design criteria, and the water quantity and quality standards, but this is not yet a policy.

- Developer GTA: The organization and core group working with LID have always been interested in doing this work, as a green developer seems to have always had a leadership approach.

- Developer ON: The organizational has prepared a strategy and corporate mission revolving around building design and environmental footprint. Tier I could do more done to address SWM

4. Have you installed or considered GSI that extended across public spaces and in privately land? If yes, have these GSI installations been funded through a public-private partnership model?

- Kitchener: City has installed and funded GSI projects on private lands. External funding has been made available for GI on private lands through federal and provincial programs for LID demonstrations. Additional funding for the stormwater credit program and outreach program was provided to REEP Green Solutions by the City when the MOE funding ended.

- Mississauga: The City has not considered or participated in P3 models. For the most part, if GI is on private lands, it is funded by private sector, and if within the ROW it is through capital budget. However, a private-public opportunity project was run, which speaks as to what can be done. It was conducted with EcoSource and TRCA and neighbourhood group to convert paved area to community garden. 
- Toronto: Cases for a pilot were assessed on individual site conditions. There is no clear direction on how to approve funding. A challenge will be how to maintain the GSI over its life-span. There are also issues with being careful to not set a precedent in allowing stormwater runoff to enter the ROW (i.e., it needs to be managed on private sites).

- Vaughan: Metro Centre is not part of a P3, but through the development application process, land owners and developers are committed to sustainability and the public realm, which will include the revitalization of Black Creek through ecological repair that will address flooding.

- Waterloo: Through the hiring of REEP, there will be demonstration projects, where City partially funds the design of private project, and then owner will then pay for installation. In other example, City has installed infiltration gallery on private lands.

- Developer GTA: Has not installed GI in the public ROW. However, a street tree project demonstrates the potential for P3. The tree pit required an appropriate volume with the soil in both public and private properties was permitted in the soil calculation.

- Developer KW: Has not built GI in the public ROW. Would need to understand the incentive to invest beyond the property boundary. Concern that the municipality would inhibit it.

- Developer ON: Would consider P3 if the developer could hand over the design of the features that are in the public ROW. Developer is constrained by the future private land owner or condominium corporation. Clarity is required if Insurance would cover damaged Gl.

5. Has your organization or municipality tracked the performance of the GSI installations, policies and instruments used? How?

- Kitchener: A formal process and database for stormwater credit program tracks the number of sites, the type of installations, and parameters of the GSI. When asset is created at the City, it is designated for asset management (in the past it was SWM pond and pipe), and is being championed to add LIDs. The performance is monitored by external consultants; and Operations for maintenance. Metrics are also collected for amount of infiltration.

- Mississauga: Monitors capital budget for the program, and performance of GI units are tracked by CVC. GIS mapping on the uptake of the SWM is through development applications, plus all public ROW programs. Through the SW credit, the City will be able to track GSI implemented and success rate. Has not requested monitoring of GSI on private sites. A challenge is to track 
APPENDIX E: RESPONSES TO INTERVIEW QUESTIONS

STORMWATER MANAGEMENT: ONTARIO MUNICIPAL POLICIES FOR GREEN INFRASTRUCTURE

stormwater charge units for condo property owners.

- Toronto: Green Streets staff are tracking the performance of constructed pilot projects with periodic visual monitoring, and are including designs for more elaborate remote sensing monitoring systems on proposed pilot projects.

- Vaughan: The streetscape and GI within the ROW are tracked by a working group through a centralized database system. The City is still at an early stage, but intends to track SWM conveyance controls, ponds and cisterns owned by the City.

- Waterloo: The City maintains an integrated GIS database with billing, online application system and maintenance of the GI for the SW fee and credit program. This system tracks the type and number of SWM applications, and is easy to manage.

- Developer KW: The property owner works with the stormwater utility to track coverage of GSI annual maintenance through a certified salt contractor ( $2 x$ a year).

- Developer ON: All LEED projects require metrics in term of water consumption and credits. Once the site is handed over to the condo, there is continued tracking by the municipality for both quantity and quality through a third party.

6. What type of outreach, education and training has been provided to you, internal staff, external service providers, stewardship groups, private-sector developers, and the general public?

- Kitchener: Training is outlined through the Master Plan process. Internal staff attend educational seminars and workshops to be able to provide direction of the SWM policies, LID technologies, and engage with external service providers. Community outreach is coordinated through an external NGO, REEP, with targets to meet annually. REEP green solutions provides the community and outreach to increase awareness. In cooperation with the City, it runs training seminars, webinars, rain barrel drives, visits to rate payers and industry.

- Mississauga: Internal awareness workshops across the City departments (e.g., lunch-and-learn) on the Gl process from planning to design, landscaping, and maintenance. Public outreach and general education programs are geared to school programs in the City. An online tool and resources, as well a phone number for inquires is available.

- Toronto Outreach and engagement to launch the new Green Streets Technical Guidelines project is ongoing, and a thorough communications plan for the larger roll-out is in progress. 
Education is essential and a formal training program is under development for different audiences. Mechanisms may include: tours (public and senior staff); LID demonstrations; lunchand-learn lectures to the Working Group (staff, project teams in ROW); outreach to schools (via School Board); and eco-literacy (education) through the ROM centre for biodiversity; and a new program Website. A high-level public presence will be provided at key events such as the Green Infrastructure Forum in November (2016). The City will help to build capacity for consultants and contractors by working closely with the CVCA and TRCA to develop training programs.

- Vaughan: As the City builds its program, information sharing will be a foundation. To build a resilient City strategically within the constraints of available resources, the City will take an approach to address education from as many angles as possible. The City is an experimental stage, trying to be innovative in a way that is sustainable. Vaughan has developed communications for each study \& project. Through the process of designing the detailed pond, there will be an education and communication strategy \& public outreach which will be launched. A quarterly newsletter will update the public about stormwater, what is going on in their city, and what is the City is doing for them.

- Waterloo: Staff have access to and attend conferences and workshops. Presentations have also been provided by CVC and TRCA, along with sharing their knowledge, and manuals for operations and maintenance for GI on SWM. Expertise is built through experience working on GSI installations on public lands. When improving the design, the Engineering Team ultimately approves the site plan development applications, with internal staff knowledgeable of $\mathrm{Gl}$. Coordination at this point only with Engineering and Planning. Public outreach is coordinated with REEP, the distribution of an annual stormwater rate brochure, and maintain a profile of the program and the City's activities at appropriate events.

- Developer GTA: Education has been iterative over time working with academia, municipalities, and consultants. The sector has also provided for numerous learning opportunities on GSI through workshops, conferences and other networking events. Community outreach is important, especially when dealing with suburban sites, as there are usually areas of environmental significance. But if you can integrate these with the community then you create a much better sense of place.

- Developer KW: Very motivated to retain the industry recognition for their LID. In a competitive market, it is very important to stay ahead of the practice and maintain the public lens. Ongoing 
APPENDIX E: RESPONSES TO INTERVIEW QUESTIONS

STORMWATER MANAGEMENT: ONTARIO MUNICIPAL POLICIES FOR GREEN INFRASTRUCTURE

knowledge is required, and so constantly attending and keeping up to date with emerging technology. Also imparting that knowledge to the tenants, as to why it is important and what we are doing? A one-stop shop, where someone comes out to the company (e.g. REAP), which is funded by the municipality was extremely useful. RAIN program which is funded annually.

- Developer ON: Have a large interdisciplinary qualified team that takes a coordinated approach to development and LID. The importance of education and training was implied.

Communication with external organizations is vital. A lot of resistance to new ideas like GSI, comes from the municipal service staff. Other issues include review by other departments who do know the planning rationale, which makes it frustrating, from developer perspective.

Developer and planners may want this GSI to work in the City, but if there is a break down in communication and knowledge sharing, it causes undue delays.

7. In addition to the responses from the previous six questions, the participants offered the following best practices and lessons learned from their individual experiences:

- Kitchener: A municipality has typically not been a strong body of knowledge on SWM and GI, or an environment where departments willingly interact and share. By creating a new SWM Utility as a large cross-departmental program, it invited other departments staff to participate. It is important to have staff at the municipality who are interested in GI working at the utility. A funding mechanism is essential for SWM and the stormwater charge is important step.

- Mississauga: The City planned for changes ahead in Provincial Policy. Working under guidance of the legislative standards from three Conservation Authorities, the City set a very high voluntary standard, which will be consistent with the MOE guidance manual for LID. City has learned from experience with CVC pilots, and was comfortable in developing their criteria. There is lots of staff support, and council support. The next important step is the resources to design and build, which takes a number of year for capital projects. Challenge is to track all the SWM infrastructure in the ground, ideally through a hand-held software tool.

- Toronto: The development of new standards through a collaborative/interdivisional multidisciplinary approach was important as it will be applicable to both capital works projects and private developments through the site plan approval, creating a standardized approach to GSI. It will have a top-down approach which is necessary for wide-spread adoption and will provide clear direction to the development community and staff alike. A program and budget 
APPENDIX E: RESPONSES TO INTERVIEW QUESTIONS

STORMWATER MANAGEMENT: ONTARIO MUNICIPAL POLICIES FOR GREEN INFRASTRUCTURE

will include extensive training for planning/design/construction/approval staff - to build capacity to deliver on the new GSI work. The City is reviewing a stormwater charge which would fund the program.

- Vaughan: A coordinated approach is required to integrate Council priorities for sustainable urban design, and emerging principles for SWM in term of LIDs. A Streetscape Working Group, has members of all the relevant departments from Policy, Design, Implementation and Monitoring and Maintenance. This group is coordinated, centralized and could integrate GSI. In 2014 for City Streetscape Improvement Strategy was approved and a follow-up is the LIVING Document, which applies to urban areas and heritage conservation districts.

- Waterloo: A lesson learned from developing incentives and subsidies is to consider potential future opportunities by looking at other cities. The credit for a Green Roof only qualifies for non-residential properties, and was not examined for high-rise or mid-rise residential, which continues to take shape in Waterloo.

- Developer GTA: Developing high-rise residential in Toronto with GSI is very challenging, but there are a number of heavily contested places, not in what the developer wants to put there, but what may be in the subsurface. In addition to the technical challenges, there are management and operational challenges faced if a developer were to install GSI and LID, but the condo boards that takes over does not commit the resources and costs for regular and specialized maintenance, then they take over the landscape of the common elements.

- Developer KW: lessons learned is that GSI retrofits are more feasible on larger buildings and properties. With some older smaller buildings, a cost-benefit analysis will indicate the GSI retrofit creates an insignificant credit based on the size of the building. So the larger the lot the bigger the return.

- Developer ON: Presenting a high-level view can meet the objectives of everyone in the long term, will avoid unnecessary objections, where any one can stop or delay a project. 


\section{Reference List}

Abramowicz, E., Coutinho, W., Gavel, A., Graham, K., Loewen, N., Marquis, T., \& Smith, A. (2015, December). The People's Plan for the Riverfront Ribbon. Retrieved from Eco/Logical Design Lab: http://ecologicaldesignlab.ca/wpcontent/uploads/2016/02/Riverfront-Ribbon_PeoplesPlan2015_Final_Low-1.pdf

Adler, M. (2013, 10 13). Many Toronto stormwater ponds are full of sediment and need dredging. Retrieved 11 24, 2014, from Inside Toronto: www.insidetoronto.com/newsstory/4141450-many-toronto-stormwater-ponds-are-full-of-sediment-and-need-dredging/

Amborski, D. (2011). Alternatives to Development Charges for Growth Related Capital Costs. Toronto: Residential and Civil Construction Alliance of Ontario (RCCAO).

Amborski, D. (2015, September). Fiscal Reform: Municipal Finance and Local Governance. [lecture PL-8103]. Toronto: Ryerson Universtiy, School of Urban and Regional Planning.

Amborski, D. (2015, October). Land Value Capture - Lecture for Finance and Local Governance [MPL-8103]. Toronto: Ryerson University, School of Urban and Regional Planning.

Berthiaume, J., Quiroz, E., \& Ivey, J. (2015, August 11). Facilitating Fees. Retrieved from StormwateReport: http://stormwater.wef.org/2015/08/facilitating-fees/

Bird, R., \& Slack, E. (1991). Financing Urban Growth. Canadian Tax Journal, 39(5), 12881304.

Blakelock, C., \& Maynes, C. (2016). Roads and Runoff: Implementing Green Streets in the Greater Goldern Horsehoe [Workshiop Discussion Paper, March 1, 2016]. Mississauga, ON: Green Communities Canada in partnership with Credit Valley Conservation (CVC).

Bloom Centre for Sustainability. (2012, January). Water Innovation Forum: Driving Adoption of Sustainable Water Solutions in the Ontario Food Processing Sector. Retrieved from Water Innovation Forum: http://bloomcentre.com/driving-adoption-of-sustainable-watersolutions-in-the-ontario-food-processing-sector/

Bloom Centre for Sustainability; XPV Capital. (2010). The Water Opportunity for Ontario. Mississauga: The Bloom Centre for Sustainability.

Canada Green Building Council; LEED Canada. (2016, March). Going green with LEED. Retrieved from Canada Green Building Council (CaGBC): www.cagbc.org/CAGBC/LEED/CAGBC/Programs/LEED/Going_green_with_LEE.aspx

City of Edmonton. (2011). Low Impact Development Best Management Practices Design Guide Edition 1.0. Environmental Planning group, Drainage Services, Edmonton.

City of Kitchener. (2015, April). Stormwater Utility. Retrieved from City of Kitchener: www.kitchener.ca/en/livinginkitchener/Stormwater_Utility.asp

City of London. (2015, December 8). Water and Stormwater By-law WM-28. Retrieved from City of London, Ontario: www.london.ca/city-hall/by-laws/Documents/wastewater-andstormwater-WM28.pdf

City of Mississauga. (2010). Green Development Standards: Going Green in Mississauga. Mississauga, ON: City of Mississauga Planning \& Building Department.

City of Mississauga. (2015, November). Stormwater Charge. Retrieved from City of Mississauga: www.mississauga.ca/portal/stormwater/charge

City of Mississauga. (2015). Stormwater Credit Program provides Multi-Residential and/ or Non-Residential Properties. City of Mississauga: Environment and Conservation.

City of Toronto. (2009). Wet Weather Flow Master Plan (WWFMP). Toronto. 
City of Toronto. (2010). Low Impact Development Stormwater Management Planning and Design Guide (Version 1.0). Toronto: Toronto City Planning.

City of Toronto. (2013). Expansion of the Basement Flooding Protection Program's Priority Study Areas [Toronto Staff Report]. Toronto.

City of Toronto. (2013). Toronto Green Standard (version 2.0). Toronto.

City of Toronto. (2014). 2013 Annual Report on Toronto City Planning.

City of Vaughan. (2011). Vaughan Metropolitan Centre Urban Design Guidelines. Vaughan.

City of Vaughan. (2014). Stormwater Management Master Plan, West Vaughan Employment Area, Municipal Class Environmental Assessment (W11-259). Vaughan, ON.

City of Vaughan. (2016, March 22). Stormwater Infrastructure Funding Study-City Wide [Council Meeting]. Retrieved from City of Vaughan: www.vaughan.ca/council/minutes_agendas/AgendaItems/Finance0229_16_4.pdf

Complete Streets for Canada. (2016, March). Retrieved from Complete Streets for Canada: http://completestreetsforcanada.ca/

Coutinho, W. (2016, March). Site Visit: Green Infrastructure Pilot in Missauga (Central Parkway E.). Mississauga, ON.

Coutinho, W. (2016, February). Site Visit: Green Street Pilot Demonstration in Right-of-Way in Toronto (South Station St. and Weston Rd.). Toronto, ON.

Credit Valley Conservation. (2014, August). Grey to Green Road Retrofits: Optimizing Your Infrastructure through Low Impact Development. Retrieved from Credit Valley Conservation (CVC): www.creditvalleyca.ca/wpcontent/uploads/2014/08/Grey-to-GreenRoad-ROWRetrofits-Complete_1.pdf

Credit Valley Conservation. (2014, July). King Street Bioretention Planters. Retrieved from Credit Valley Conservation (CVC): www.creditvalleyca.ca/green_project/marker/kingstreet-bioretention-planters/

Credit Valley Conservation. (2014, July). Low Impact Development Road Retrofits: Optimizing Your Infrastructure Assets through Low Impact Development [Grey to Green]. Retrieved from Credit Valley Conservation (CVC): www.creditvalleyca.ca/wpcontent/uploads/2014/08/Grey-to-Green-Road-ROW-Retrofits-Complete_1.pdf

Credit Valley Conservation. (2014, June). Low Impact Development: Public Lands Retrofits. Mississauga, ON: Credit Valley Conservation (CVC). Retrieved from Credit Valley Conservation (CVC).

Credit Valley Conservation. (2015). Grey to Green Enhanced Stormwater Management Master Planning Guide [DRAFT]. Retrieved from Credit Valley Conservation (CVC): www.creditvalleyca.ca/wp-content/uploads/2016/01/ORGuide.pdf

Credit Valley Conservation. (2016). Low Impact Development Guidance Documents. Retrieved from Credit Valley Conservation (CVC): www.creditvalleyca.ca/low-impactdevelopment/low-impact-development-support/stormwater-management-lid-guidancedocuments/

Credit Valley Conservation. (2016, March). Showcasing Water Innovation: Low Impact Development Map. Retrieved from Credit Valley Conservation (CVC): www.creditvalleyca.ca/low-impact-development/green-projects-map/

Credit Valley Conservation; Toronto and Region Conservation Authority. (2011). The Low Impact Development Stormwater Management Planning and Design Guide (v.1.0). Retrieved from Credit Valley Conservation (CVC): www.creditvalleyca.ca/wpcontent/uploads/2012/02/lid-swm-guide-chapter1.pdf 
Di Gironimo, L. (2016). Toronto Water [Presentation to Ryerson University Master of Planning Students]. PL8312 - Politics and City Building. Toronto: City of Toronto.

Drake, J., Bradford, A., \& Van Seters, T. (2012). Evaluation of Permeable Pavements in Cold Climates. Kortright Centre, Vaughan: Toronto and Region Conservation Authority.

EcoJustice. (2008). Green Cities, Great Lakes: Using Green Infrastructure to reduce Combined Sewer Overflows. Toronto: EcoJustice, formerly Sierra Legal.

Federation of Canadian Municipalities. (2015, November). Water Sector Funding. Retrieved from FCM Green Municipal Fund: www.fcm.ca/home/programs/green-municipalfund/what-we-fund/projects/water-funding.htm

Frederick, R. P. (2015). Overcoming Barriers to Implementation of LID Practices. In M. T. Clark, Low Impact Development Technology - Implementation and Economics [Low Impact Development Conference Preceedings, 2011 (Philadelphia, PA)] (pp. 17-25). Reston, VA: American Society of Civil Engineers.

Goo, R. L. (2016). Thoughts about Green Streets and Public Rights of Ways [US Environmental Protection Agency]. Roads and Runoff Workshop (March 1, 2016). Mississauga, ON: Green Communities Canada.

Government of Canada. (2014, December 18). Canada-Ontario Agreement on Great Lakes Water Quality and Ecosystem Health, 2014. Retrieved from Environment and Climate Change Canada: https://ec.gc.ca/lcpe-cepa/default.asp?lang=En\&n=E9A42FF1-1

Government of Canada. (2014). Tri-Council Policy Statement: Ethical Conduct for Research Involving Humans (2nd edition). Retrieved from Panel of Research Ethics: https://tcps2core.ca/welcome

Government of Ontario. (2011, March 2). Water Opportunities and Water Conservation Act, 2010 (WOWCA). Retrieved from e-Laws Ontario: www.ontario.ca/laws/statute/10w19

Government of Ontario. (2015, January). Ontario Water Resources Act, R.S.O. 1990 (OWRA). Retrieved from e-Law: www.ontario.ca/laws/statute/90o40\#BK86

Government of Ontario. (2016, February). Environmental Protection Act, R.S.O. 1990 (EPA). Retrieved from e-Laws: www.ontario.ca/laws/statute/90e19

Green Communities Canada. (2016). Roads and Runoff: Implementing Green Streets in the Greater Golden Horseshoe [Workshop, March 1]. Mississauga, ON: Credit Valley Conservation and Green Communities Canada.

International Joint Commission. (2012). Great Lakes Water Quality Agreement, 2012. Retrieved from International Joint Commission (IJC): www.ijc.org/en_/Great_Lakes_Water_Quality

Lawson, S. O. (2010, 1 1). A Planning Framework For Low Impact Development (LID) In Stormwater Management An Ontario Perspective. Ryerson University, Master of Applied Science in the Program of Environmental Applied Science and Managemen. Toronto: Ryerson University.

Mascarin, J. (2014, October 3). Securing Public Benefits from Urban Development (Lecture). PL8102 - Institutional and Legal Context of Planning. Toronto: Ryerson University.

Maynes, C. (2015). Green Infrastructure and Stormwater Management: A Strategy for Making it Happen. Green Infrastructure Ontario Coalition (pp. Day 1, March 25). Brampton, ON: Toronto and Region Conservation Authority (TRCA).

Ministry of Municipal Affairs and Housing. (1990). Planning Act, 1990. Retrieved from Government of Ontario: www.mah.gov.on.ca/Page1760.aspx 
Ministry of Municipal Affairs and Housing. (2008). Community Improvement Planning Handbook. Toronto: Ministry of Municipal Affairs and Housing (MMAH).

Ministry of Municipal Affairs and Housing. (2013). Development Charges in Ontario, Consultation Document. Toronto: Queen's Printer of Ontario.

Ministry of Municipal Affairs and Housing. (2014). Provincial Policy Statement, 2014. Toronto: Ministry of Municipal Affairs and Housing (MMAH).

Ministry of Municipal Affairs and Housing. (2015). Co-ordinated Land Use Planning Review, Summary Report on Town Hall Meetings. Retrieved from Ministry of Municipal Affairs and Housing (MMAH): www.mah.gov.on.ca/AssetFactory.aspx?did=11126

Ministry of Municipal Affairs and Housing. (2015, 04). Growth Plan for the Greater Golden Horseshoe, 2006; Office Consolidation, June 2013. Retrieved from Ministry of Municipal Affairs and Housing (MMAH): www.placestogrow.ca

Ministry of the Environment. (2003). Stormwater Management Planning and Design Manual. Toronto: Government of Ontario.

Ministry of the Environment and Climate Change. (2012, December). Ontario's Great Lakes Strategy. Retrieved from Government of Ontario: www.ontario.ca/document/ontariosgreat-lakes-strategy

Ministry of the Environment and Climate Change. (2015, November 3). Bill 66, Great Lakes Protection Act, 2015. Retrieved from Legislative Assembley of Ontario:

www.ontario.ca/page/protecting-great-lakes

Ministry of the Environment and Climate Change. (2015, Feburary 4). Interpretation Bulletin:

Ontario Ministry of Environment and Climate Change Expectations Re: Stormwater Management. Retrieved from RAIN Community Solutions (Green Communities Canada): www.raincommunitysolutions.ca/wp-content/uploads/2015/07/MOECCinterpretation-bulletin-re-stormwater-management.pdf

Ministry of the Environment and Climate Change. (2015). Ontario's Climate Change Strategy. Retrieved from Government of Ontario: www.ontario.ca/page/climate-change-strategy

Neuman, W. L., \& Robson, K. (2015). Basics of Social Research: Qualitative and Quantitative Approaches. (3rd, Ed.) Toronto: Pearson.

Ontario Municipal Benchmarking Initiative. (2014). 2014 Performance Measurement Report. Hamilton, Ontario: Ontario Municipal Benchmarking Initiative (OMBI).

Ontario Professional Planners Institute . (2012, June 1). Independent Professional Judgment Standards of Practice adopted by Council (June 2012).

Ontario Professional Planners Institute. (2015). Professional Code of Practice. Retrieved from http://ontarioplanners.ca/Knowledge-Centre/Professional-Code-of-Practice

Porter-Bopp, S., Brandes, O. M., \& Sandborn, C. (2011). Peeling Back the Pavement: A Blueprint for Reinventing Rainwater Management in Canada's Communities. Victoria: POLIS Project on Ecological Governance, University of Victoria; Environmental Law Centre, University of Victoria.

Rodriguez-Valencia, A. (2015). The Emergence of Green Street Programs in the U.S.: A Study of Three Cities. Thesis Dissertation. California, U.S.: University of California, Davis.

Saxe, D. (2015, March). More Cities adopting stormwater fees: you pave, you pay. Retrieved from Envirolaw: www.envirolaw.com

Saxe, D. (2015, November). Stormwater Fees, You pave, You pay. Municipal World, 33-34. Slack, E. (1994). Development Charges in Canadian Municipalities: An Analysis. Toronto Ontario: ICURR Publications. 
Slack, E. (2006). The Impact ofMunicipal Finance and Governance on Urban Sprawl. International Symposium on Urban Impacts: Global Lessons for the Great Lakes Basin. Chicago, Illinois: Institute on Municipal Finance and Governance, Munk Centre for International Studies.

Tassonyi, A. (2002). Municipal Budgeting. Canadian Tax Journal, 50(1), 181-198. Toronto and Region Conservation Authority. (2008). Performance Evaluation of Permeable Pavement and a Bioretention Swale. Toronto: Sustainable Technologies Evaluation Program (STEP); TRCA.

Toronto and Region Conservation Authority. (2009). Review of the Science and Practice of Stormwater Infiltration in Cold Climates. Toronto, Ontario: Sustainable Technologies Evaluation Program (STEP), TRCA.

Toronto and Region Conservation Authority. (2012, August). Stormwater Management Criteria (v.1.0). Retrieved from Sustainable Technologies Evaluation Program (STEP): http://sustainabletechnologies.ca/wp/wp-content/uploads/2013/01/SWM-Criteria2012.pdf

Toronto and Region Conservation Authority. (2013). Evaluation of Underground Stormwater Infiltration Systems. Toronto, ON: Sustainable Technologies Evaluation Program (STEP); TRCA.

Toronto and Region Conservation Authority. (2013, August). Toronto Storm Infographic: July 8, 2013. Retrieved from Toronto and Region Conservation Authority (TRCA) Flood Management Service: http://trca.on.ca/flood-management-service/floodimages/TOFloodInfographic_FINAL.pdf

Toronto Water. (2015). Funding Options for Paying for Toronto Water's Stormwater Management Capital Program [Staff Report RE:EX10.26]. City of Toronto.

Transport Canada. (2011). Active Transportation in Canada: a resource and planning guide. Retrieved from Federation of Canadian Municipalities (FCM): www.fcm.ca/Documents/tools/GMF/Transport_Canada/ActiveTranspoGuide_EN.pdf

U.S. EPA. (2010). Green Infrastrucuture Case Studies: Municipal Policies for Managing Stormwater with Green Infrastructure. Washington: U.S. EPA Office of Wetlands, Oceans and Watersheds.

U.S. Green Building Council. (2013, November 13). LEED v. 4 for Homes Design and Construction (Homes + Midrise). Retrieved from U.S. Green Building Council (USGBC): www.usgbc.org/resources/leed-v4-homes-and-midrise-ballot-version

U.S. Green Building Council. (2014, October 1). LEED v4 for Neighborhood Development (ND). Retrieved from U.S. Green Building Council (USGBC): www.usgbc.org/sites/default/files/LEED\%20v4\%20ND_10.01.14_current_0.pdf

U.S. Green Building Council. (2015, July 1). LEED 44 for Building Design and Construction $(B O+C)$. Retrieved from U.S. Green Building Council (USGBC): www.usgbc.org/sites/default/files/LEED\%20v4\%20BDC_10.01.15_current_0.pdf

U.S. Green Building Council. (2016, January 4). LEED v.4 for Building Operations and Maintenance $(B O+M)$. Retrieved from U.S. Green Building Council (USGBC): www.usgbc.org/sites/default/files/LEED\%20v4\%20EBOM_01.04.16_current.pdf 


\section{Glossary of Terms}

"Active Transportation" refers to all forms of human-powered transportation. Within the urban environment, this includes walking, cycling, using a non-mechanical wheelchair, in-line skating or skateboarding, which are facilitated through the right-of-way on sidewalks, dedicated laneways, and sharing of the roadway. Associated benefits aside from being an affordable transportation option, include improved human physical and psychological health, opportunities to increase social and community interaction, and a reduction on environmental pressures through reduced use of automobiles and lower emissions (Transport Canada, 2011).

"Combined Sewer Overflows" or "CSOs" are an outdated and historic engineering practice that transports both sanitary sewage or wastewater and stormwater through runoff through the same system to an end of pipe treatment facility. In the event of large and high-intensity storms, where a rush rainwater runoff is in the system was designed to by-pass the treatment facility so as not to cause damage to infrastructure, and would result in direct discharge of untreated wastewater from CSO outfalls into local water bodies (EcoJustice, 2008).

"Complete Streets" is a term used to describe streets that are designed for all ages, abilities, and modes of travel, including vehicles and those defined by "active transportation". The complete streets concept includes elements for environmental sustainability, such as street trees and sidewalk planters, which as an evolutionary morphology should incorporate designs for green stormwater infrastructure (Complete Streets for Canada, 2016).

"Green Infrastructure" or "GI" and "Green Stormwater Infrastructure" or "GSI" are used interchangeably to describe approaches provided by engineered natural systems to manage rain where it falls and stormwater runoff. GI means natural and human made elements that provide ecological and hydrological functions and processes (Ministry of Municipal Affairs and Housing, 1990). GSI also includes engineered wetlands and other naturalized systems such as green roofs and rainwater harvesting (Credit Valley Conservation, 2014).

"Green Streets" are a roadway or thoroughfare that manages stormwater runoff at its source by capturing and temporarily retaining, infiltrating, and evapotranspiration the runoff through an engineered naturalized system, within the right-of-way and adjacent facilities (Goo, 2016).

"Grey infrastructure" in the context of stormwater management, refers to the conventional practice of managing through a series of collection systems, conveyance controls and piping, such as storm 
sewers, culverts, and drainage pipes integrated within the right-of-way (roads and bridges), which are then conveyed to outfalls in either man-made stormwater retention ponds, or local rivers and lakes (Credit Valley Conservation, 2014).

"Leadership in Energy and Environmental Design" or "LEED" is a rating system that is recognized as the international mark of excellence for green building in 150 countries. Since 2002, the Canada Green Building Council (CaGBC) and LEED Canada have been redefining the buildings and communities where Canadians live, work and learn (Canada Green Building Council; LEED Canada, 2016). Applicable stormwater management practices fall under v.4 of LEED for Sustainable Sites, Smart Location and linkage, Neighborhood Pattern and Design, and Green Infrastructure \& Buildings in categories for: Building Design and Construction (BD+ $+C)$ (U.S. Green Building Council, 2015), Building Operations and Maintenance (BO+M) (U.S. Green Building Council, 2016); Homes Design and Construction (Homes + Midrise) (U.S. Green Building Council, 2013); and Neighborhood Development (ND) (U.S. Green Building Council, 2014)

LEED "Heat Island Reduction" is a category under BD+C, BO+M, Homes + Midrise, and ND with the intent to minimize effects on microclimates and human and wildlife habitats by reducing heat islands.

LEED "Open Space" is a category under BD+C with the intent to create exterior open space that encourages interaction with the environment, social interaction, passive recreation, and physical activities.

LEED "Outdoor Water Use Reduction" is a category under ND with the intent to reduce outdoor water consumption.

LEED "Rainwater Management" is a category under BD+C, BO+M, Homes + Midrise, and ND with the intent to reduce runoff volume and improve water quality by replicating the natural hydrology and water balance of the site, based on historical conditions and undeveloped ecosystems in the region.

LEED "Reduced Parking Footprint" is a category under ND with the intent to minimize the environmental harms associated with parking facilities, including automobile dependence, land consumption, and rainwater runoff.

LEED "Site Assessment" is a category under BD+C with the intent to assess site conditions before design to evaluate sustainable options and inform related decisions about site design. 
LEED “Site Development - Protect or Restore Habitat is a category under BD+C, BO+M, and ND with the intent to conserve existing natural areas and restore damaged areas" to provide habitat and promote biodiversity.

LEED "Site Improvement Plan" is a category under BO+M with the intent to preserve and improve ecological integrity while supporting high-performance building operations.

LEED "Site Management" is a category under BO+M with the intent to preserve ecological integrity and encourage environmentally sensitive site management practices that provide a clean, well-maintained, and safe building exterior while supporting highperformance building operations and integration into the surrounding landscape.

LEED "Total Water Use" is a category under Homes + Midrise with the intent to reduce demand for water through high-efficiency fixtures and efficient landscaping practices.

LEED "Tree-Lined and Shaded Streetscapes" is a category under ND with the intent to encourage walking and bicycling and discourage speeding. To reduce urban heat island effects, improve air quality, increase evapotranspiration, and reduce cooling loads in buildings.

"Low Impact Development" or "LID" is an approach to land development (or re-development) that works with nature to manage stormwater as close to its source as possible, to meet objectives for water quality and quantity (U.S. EPA, 2010). LID comprises a set of site design strategies that minimize runoff and distributed, small scale structural practices that mimic natural or predevelopment hydrology through the processes of infiltration, evapotranspiration, harvesting, filtration and detention of stormwater. These practices can effectively remove nutrients, pathogens and metals from runoff, and they reduce the volume and intensity of stormwater flows (Credit Valley Conservation; Toronto and Region Conservation Authority, 2011).

"Stormwater" is rainwater, snowmelt, or other form of precipitation that has contacted the ground or any surface. Upon such contact, stormwater follows the principles of the water cycle, which include infiltration, evapotranspiration, run-off, storage in water bodies, and precipitation (Ministry of the Environment, 2003).

"Water Balance" refers to preserving the pre-development hydrology of a watershed, which typically consists of runoff, infiltration and evapotranspiration (City of Toronto, 2009, p. 4). 